UNIVERSIDADE DE SÃO PAULO

FACULDADE DE ZOOTECNIA E ENGENHARIA DE ALIMENTOS

MARIA HELENA COELHO CRUZ

Efeito da melatonina sobre a viabilidade e expressão gênica de oócitos suínos e células do cumulus maturados in vitro

Effects of melatonin on viability and gene expression of porcine oocytes and cumulus cell matured in vitro 
Efeito da melatonina sobre a viabilidade e expressão gênica de oócitos suínos e células do cumulus maturados in vitro

"Versão Corrigida"

Tese de Doutorado apresentada à Faculdade de Zootecnia e Engenharia de Alimentos da Universidade de São Paulo, como parte dos requisitos para obtenção do Título de Doutor em Ciências.

Área de Concentração: Qualidade e Produtividade Animal

Orientador: Prof ${ }^{a}$. Dra ${ }^{a}$ Cláudia Lima Verde Leal 
Ficha catalográfica elaborada pelo

Serviço de Biblioteca e Informação, FZEA/USP, com os dados fornecidos pelo(a) autor(a)

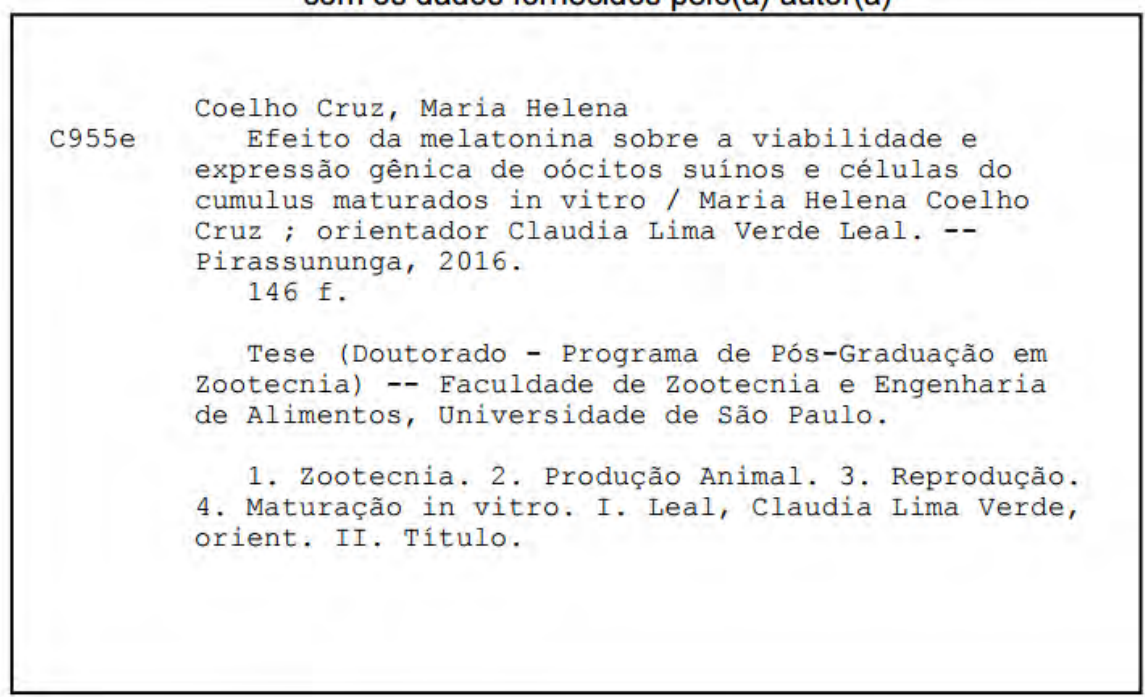

Permitida a cópia total ou parcial deste documento, desde que citada a fonte - o autor 


\section{Efeito da melatonina sobre a viabilidade e expressão gênica de oócitos suínos e células do cumulus maturados in vitro}

Tese de Doutorado apresentada à Faculdade de Zootecnia e Engenharia de Alimentos da Universidade de São Paulo, como parte dos requisitos para obtenção do Título de Doutor em Ciências.

Área de Concentração: Qualidade e Produtividade Animal

Data da aprovação: 02/09/2016

Banca Examinadora:

Claudia Lima Verde Leal - Presidente da Banca Examinadora

Prof. Dra. da FZEA/ USP - Orientador(a)

Simone Méo Niciura

Pesquisadora Dra. da EMBRAPA Pecuária Sudeste

Adriana Mercia Guratini Ibelli

Analista A, Dra. da EMBRAPA Suínos e Aves

Mariana Groke Marques

Pesquisadora Dra. da EMBRAPA Suínos e Aves

Lígia Garcia Mesquita

Especialista de Laboratório, Dra. da FMVZ/ USP 
Dedico à minha família, Jurandir, Claudia,

Luísa e Logan, pelo amor e apoio incondicional. 


\section{AGRADECIMENTOS}

A Deus por ter me permitido mais essa vitória.

À minha família: meus pais Jurandir e Cláudia, a minha irmã Luísa e ao meu esposo Logan por todo amor, carinho, compreensão, orientação, paciência... Aos meus amados avós: vovô Aldo (in memorian), vovô Bio (in memorian), vovó Senhora, vovó Lu pelo amor, atenção e carinho.

A minha orientadora, Prof. Dra. Claudia Lima Verde Leal, pela valiosa orientação, amizade, aprendizado e apoio, os quais foram fundamentais para realização desse trabalho.

Ao meu mestre Russel Reiter e a equipe do Department of Cellular and Structural Biology, UTHSCSA, San Antonio - Texas, pela amizade e valiosos ensinamentos.

A todos os meus tios, tias em especial às minhas tias Giedra, Dilvane e Branca e a todos os meus primos e primas em especial: Gal, Dinha, Jack, Leti, Ninho e Rebeca.

Aos meus grandes amigos Wal, Adriana, Débora, Fernanda, Joyce, Juliana, Leandro e Tiago por estarem sempre ao meu lado, compartilhando das alegrias e dificuldades, sem vocês não chegaria aqui.

A equipe do laboratório de citologia da FZEA: Fer, Leo, Hugo, Lígia, Kátia, Carol e Ramon, pelo aprendizado, companhia e atenção.

A Dra. Mariana Groke Marques, por disponibilizar o laboratório de reprodução da Embrapa Suínos e Aves, para finalização do meu experimento.

Aos meus grandes amigos da Embrapa, Chana, Raíra, Igor, Dani Matiolo, Mari Pizzol, Vanessa, Xande, Dra. Adriana Ibelli e Dra. Cíntia Okino, sempre atenciosos, companheiros e prestativos, sem dúvida graças a vocês esse trabalho se tornou possível.

À FAPESP, pelo apoio financeiro e institucional (processo 2012/06180-8).

A todos os estagiários que me ajudaram durante os experimentos, em especial a Fernanda Pereira, pela atenção e companheirismo. 
"O período de maior ganho em conhecimento e experiência é o período mais difícil da vida de alguém"

Dalai Lama 


\section{RESUMO}

\section{CRUZ, M. H. C. Efeito da melatonina sobre a viabilidade e expressão} gênica de oócitos suínos e células do cumulus maturados in vitro. 2016. $147 \mathrm{f}$. Tese (Doutorado) - Faculdade de Zootecnia e Engenharia de Alimentos, Universidade de São Paulo, Pirassununga, 2016.

A melatonina é um antioxidante muito eficaz e protege as células contra o estresse oxidativo causado pelas espécies reativas, e indiretamente, modula a expressão de genes associados ao ciclo celular, metabolismo oxidativo e apoptose celular. Deste modo, a suplementação da melatonina ao meio de maturação in vitro, a torna uma alternativa para promover melhorias na viabilidade das células germinativas e embrionárias. $O$ estudo 1 avaliou o efeito da adição de melatonina ao meio de maturação por meio da maturação nuclear (progressão meiótica) e citoplasmática (migração de grânulos corticais) e dos níveis de ROS em oócitos suínos maturados in vitro. A suplementação do meio de maturação com melatonina estimulou a progressão da meiose, a migração de grânulos corticais e reduziu os níveis intracelulares de ROS nos oócitos. O estudo 2 avaliou o efeito da melatonina na expressão de genes antioxidantes (Catalase, SOD1, SOD2 e GPX) envolvidos na proteção celular de oócitos e células do cumulus. A adição da melatonina ao meio de maturação influenciou positivamente a expressão dos genes antioxidantes nos oócitos e células do cumulus. $O$ estudo 3 avaliou o efeito da melatonina nos processos biológicos por meio do perfil de trascriptomas, via RNA-Seq, em células do cumulus oriundas de oócitos suínos maturados in vitro. A partir da análise de expressão diferencial foi possível identificar que a adição da melatonina ao meio de maturação influenciou 80 genes associados a nove processos biológicos (ciclo celular; proteólise; organização de citoesqueleto; via energética; adesão e transporte celular; via de sinalização; fator de transcrição; metabolismo oxidativo e apoptose; e componente celular). A suplementação do meio de maturação com melatonina potencialmente influencia a viabilidade e 0 funcionamento celular, uma vez que modulou a expressão de genes associados à processos fisiológicos essenciais, tais como: divisão celular, metabolismo energético e oxidativo, vias de sinalização e apoptose. O estudo 4 , avaliou o efeito da melatonina sobre os genes associados à viabilidade oocitária e o subsequente desenvolvimento embrionário por meio do perfil de trascriptomas, via RNA-Seq, de células do cumulus oriundas de oócitos suínos. A adição da melatonina ao meio de maturação influenciou 59 genes associados a nove funções biológicas (expansão do cumulus, comunicação em COCs, maturação nuclear, maturação citoplasmática, reparo e integridade do DNA, viabilidade oocitária, esteroidogênese, fertilização e embriogênese). Em conclusão, a suplementação do meio de maturação com melatonina influencia positivamente a maturação oócitária, reduz os níveis intracelulares de ROS, aumenta a expressão de genes antioxidantes, em adição, interfere no transcriptoma de um número expressivo de genes associados à aquisição da competência oócitária, da viabilidade embrionária e desenvolvimento subsequente.

Palavras-chave: melatonina, gametas, cultivo in vitro, RNA-seq 


\section{ABSTRACT}

CRUZ, M. H. C. Effects of melatonin on viability and gene expression in porcine oocytes and cumulus cells matured in vitro. 2016. 150 f. Thesis (Ph.D.). - Faculdade de Zootecnia e Engenharia de Alimentos, Universidade de São Paulo, Pirassununga, 2016.

Melatonin is a very effective antioxidant and protects cells against oxidative stress caused by reactive species, and indirectly modulates expression of genes associated with cell cycle, oxidative metabolism, and apoptosis. Thus, melatonin supplementation to in vitro maturation media becomes an alternative to improve the viability of germ and embryonic cells. The first study assessed the effects of adding melatonin to the maturation medium on nuclear (meiotic progression) and cytoplasmic (cortical granules migration) maturation and ROS levels in in vitro matured porcine cumulus-oocyte complexes (COCs). Melatonin supplementation stimulated meiosis progression and cortical granules migration, and reduced intracellular ROS levels in oocytes. The second study evaluated the effects of melatonin on the expression of antioxidant genes (Catalase, SOD1, SOD2, and GPX) involved in cellular protection in oocytes and cumulus cells. The addition of melatonin to the maturation medium positivity influence the expression of antioxidant genes in oocytes and cumulus cells. The third study evaluated the effect of melatonin on genes associated with biological processes through transcriptomic profile via RNA-Seq in cumulus cells derived from porcine COCs in vitro matured. Melatonin addition to maturation medium differentially affected expression of 80 genes associated with nine biological processes (cell cycle, proteolysis, cytoskeletal organization, energy pathaway, cell adhesion and transport, signalling pathway, transcription factor, oxidative metabolism and apoptosis, and cell components). The fourth study assessed the effect of melatonin on genes associated with oocyte viability and subsequent embryo development through transcriptomic profile via RNA-Seq in cumulus cells derived from porcine COCs. Melatonin in the maturation medium affected 59 genes associated with nine biological functions related with oocyte viability and embryo development (cumulus expansion, communication between cumulus cells and oocytes, nuclear maturation, cytoplasmic maturation, DNA repair and integrity, oocyte viability, steroidogenesis, fertilization and embryogenesis). In conclusion, supplementation of melatonin to maturation environment influences oocyte nuclear and cytoplasmic maturation, reduces intracellular ROS levels, positivity influence the expression of antioxidant and also interferes in the transcriptome of a significant number of genes associated with oocyte competence acquisition, embryo viability and subsequent development.

Keywords: Melatonin, gametes, in vitro culture, RNA-seq 


\section{LISTA DE FIGURAS}

Figura 1. As vias biossintéticas clássicas da melatonina em animais vertebrados.

Figura 2. Receptores de membrana (MT1 e MT2), receptor de citoplasma (MT3) e sítios de ligação nuclear (RZR/ROR) de melatonina. 26

Figura 3. Via de regulação da melatonina sobre a esteroidogênese. 31

Figura 4. Danos ao DNA induzidos por espécies reativas de oxigênio e espécies reativas de nitrogênio via cascata de apoptose. 33

Figura 5. Peroxidação lipídica na membrana mitocondrial induzida por espécies reativas de oxigênio.. 36

Figura 6. - Aspecto morfológico da progressão nuclear em oócitos suínos maturados in vitro, corados com Hoechst 33342 e avaliados por microscopia de epifluorescência.

Figura 7. Aspecto morfológico da distribuição dos grânulos corticais (GC) em oócitos suínos maturados in vitro por $44 \mathrm{~h}$, corados com com FITC-PNA, e avaliados por microscopia de epifluorescência.

Figura 8. Processamento da imagem original de oócito suíno maturado por 44 horas para quantificação de radicais livres com DCF-DA. 64

Figura 9. Taxa de maturação de oócitos suínos maturados in vitro, em meio suplementado com pFF ou PVA com ou sem a adição de $10^{-9} \mathrm{M}$ de melatonina

Figura 10. Expressão dos genes Catalase, SOD1, SOD2 e GPX em oócitos suínos maturados in vitro por $44 \mathrm{~h}$ em meios de maturação definido (PVA) e indefinido (pFF) contendo ou não $10^{-9} \mathrm{M}$ de melatonina.

Figura 11. Expressão dos genes Catalase, SOD1, SOD2 e GPX em células do cumulus oriundas de oócitos suínos maturados in vitro por $44 \mathrm{~h}$ em meios de maturação definido (PVA) e indefinido (pFF) contendo ou não $10^{-9} \mathrm{M}$ de melatonina. 86

Figura 12. Análise de integridade do RNA utilizando BioAnalizer ${ }^{\circledR}$. 97 
Figura 13. Análise de integridade das bibliotecas utilizando BioAnalizer ${ }^{\circledR}$ 98

Figura 14. (A) MA plot e (B) Diagrama de Veen do perfil de transcriptomas de células do cumulus oriundas de complexos cumulus-oócitos suínos maturados em meio acrescido ou não de melatonina, análise por RNA-Seq. 100

Figura 15. Análise por RNA-Seq do perfil de transcriptomas de células do cumulus oriundas de complexos cumulus-oócitos suínos maturados em meio acrescido ou não de melatonina. 105

Figura 16. - Mecanismos de ação indireta da melatonina sobre a expressão gênica no complexo cumulus-oócito 111

Figura 17. A) Heat-map, (B) Heatmap-distance do perfil de transcriptomas de células do cumulus oriundas de CCOs suínos maturadas in vitro em meio acrescido ou não de melatonina, determinados por RNA-Seq. 126

Figura 18. Perfil de transcriptomas de células do cumulus, oriundas de CCOs suínos maturadas in vitro em meio acrescido de melatonina, relacionado com as funções biológicas associadas à viabilidade oocitária e ao desenvolvimento embrionário. 126

Figura 19. Quantidade de genes com expressão aumentada (vermelho) ou reduzida (verde) pela melatonina, verificada por meio do perfil de transcriptomas de células do cumulus oriundas de CCOs suínos maturadas in vitro. 128

Figura 20. Mecanismos de ação indireta da melatonina sobre a expressão de genes nas células do cumulus associados à maturação oocitária e embriogênese. 136 


\section{LISTA DE TABELAS}

Tabela 1. Taxa de maturação nuclear (TMN) de oócitos suínos maturados in vitro por 36, 40 e 44 horas em meio suplementado com $10^{-9}, 10^{-6}$ ou $10^{-3} \mathrm{M}$ de melatonina. $O$ controle foi maturado sem adição de melatonina 66

Tabela 2. Taxa de maturação citoplasmática (TMC) de oócitos suínos maturados in vitro por 36, 40 e 44 horas em meio suplementado com 10-9, 10${ }^{6}$ ou $10^{-3} \mathrm{M}$ de melatonina. $\mathrm{O}$ controle foi maturado sem adição de melatonina.

Tabela 3. Níveis de ROS (média $\pm d p$ )em oócitos suínos maturados in vitro por 44 horas, em meio TCM199 (T0), TCM199 acrescido de diferentes concentrações de melatonina ( $10^{9}$ e $\left.10^{-6} \mathrm{M}\right)$, e TCM199 acrescido $1 \mathrm{mM}$ de

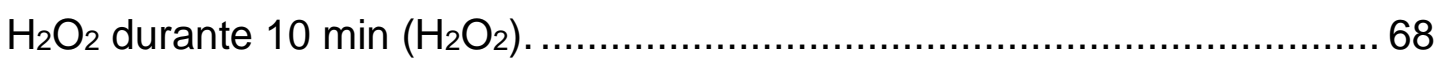

Tabela 4. Componentes e concetração utilizados no meio de lavagem....... 81

Tabela 5. Componentes e concetração utilizados no meio de maturação ... 81

Tabela 6. Sequências dos oligonucleotideos iniciadores para os genes das enzimas antioxidantes superóxido dismutases (SOD1 e SOD2), Catalase e glutationa peroxidase (GPX) e bem como para os genes constitutivos GAPDH, Ubiquitina, Histona H3. 83

Tabela 7. Níveis de expressão de genes das células do cumulus associados à suplementação de melatonina ao meio de maturação de complexos cumulus-oócitos suínos maturados in vitro. (Continua) ............................ 101

Tabela 8. Processos biológicos de transcritos que tiveram a expressão aumentada nas células do cumulus com a suplementação da melatonina ao meio de maturação. ( $n=62$; adjusted P-value <0.05; fold change >2) ...... 103 Tabela 9. Processos biológicos de transcritos que tiveram a expressão reduzida em células do cumulus com a suplementação da melatonina ao meio de maturação. ( $n=18$; adjusted P-value <0.05; fold change >2) .............. 104 Tabela 10. Genes associados à viabilidade oocitária e desenvolvimento embrionário que tiveram a expressão aumentada com a suplementação da 
melatonina ao meio de maturação em células do cumulus oriundas de CCOs suínos maturadas in vitro. ....................................................... 127 Tabela 11. Genes associados à viabilidade oocitária e desenvolvimento embrionário que tiveram a expressão reduzida com a suplementação da melatonina ao meio de maturação em células do cumulus oriundas de CCOs suínos maturadas in vitro. 128 


\section{SUMÁRIO}

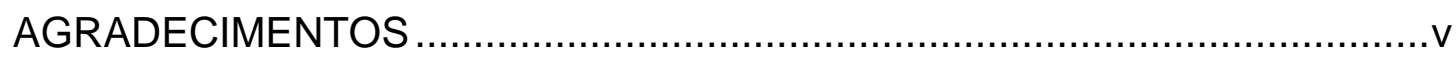

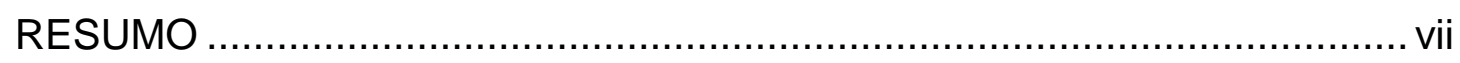

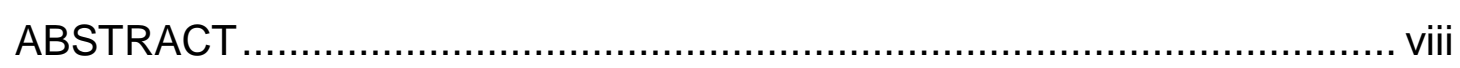

LISTA DE FIGURAS ................................................................... ix

LISTA DE TABELAS ....................................................................

CAPÍTULO I - INTRODUÇÃO E REVISÃO DE LITERATURA ..................... 15

INTRODUÇÃO .............................................................................. 16

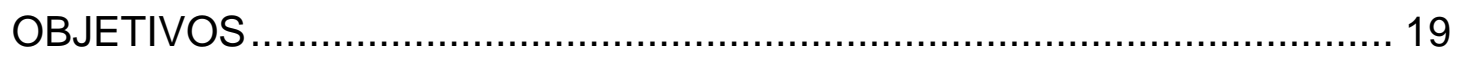

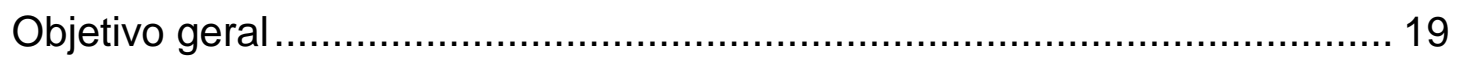

Objetivos específicos ..................................................................... 19

1.1. INTRODUÇÃO ..................................................................... 20

1.2. Importância fisiológica das espécies reativas .................................. 21

1.3. Melatonina: biossíntese e liberação em mamíferos ............................ 23

1.4. Receptores de melatonina e seus processos de transdução e

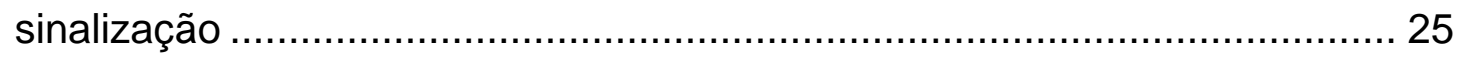

1.5. Propriedades antioxidantes da melatonina ................................... 27

1.5.1 Neutralização direta de radicais livres........................................... 28

1.5.2 Neutralização indireta de radicais livres ......................................... 29

1.6. Dano oxidativo e efeito protetor da melatonina no ovário .................... 30

1.6.1 Estresse oxidativo e efeito da melatonina no folículo........................ 31

1.6.2 Estresse oxidativo e o efeito da melatonina no oócito ......................... 34

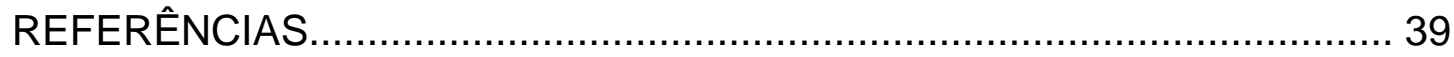

CAPÍTULO II - O EFEITO DA MELATONINA EM OÓCITOS SUÍNOS

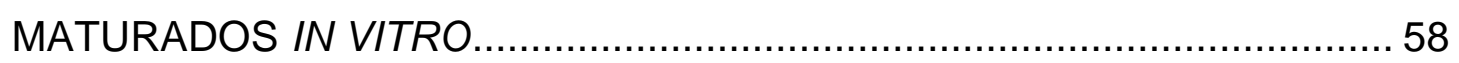

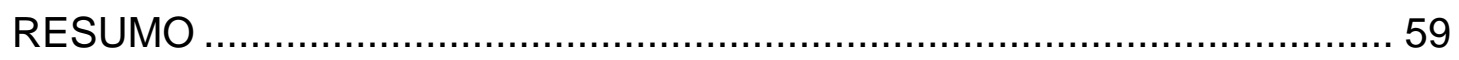

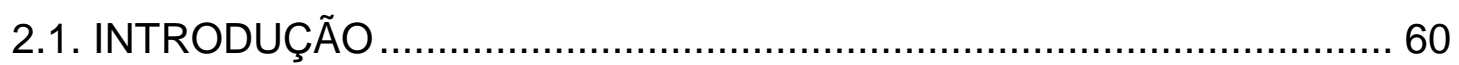

2.2. MATERIAL E MÉTODOS ............................................................ 61

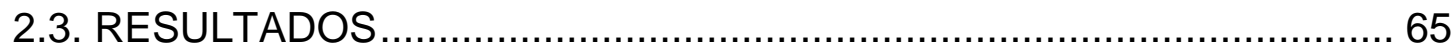

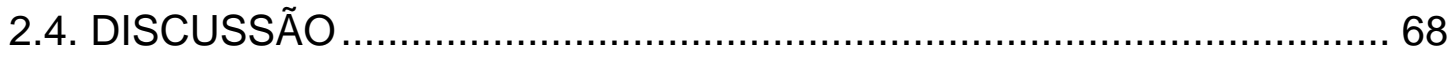

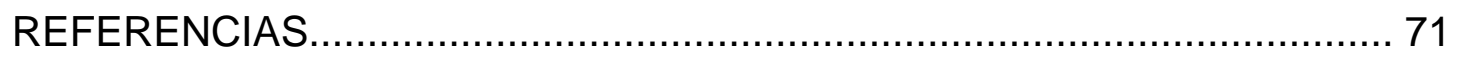


CAPÍTULO III - O EFEITO DA MELATONINA NA EXPRESSÃO DOS GENES ANTIOXIDANTES ENVOLVIDOS EM FUNÇÕES DE PROTEÇÃO CELULAR 76

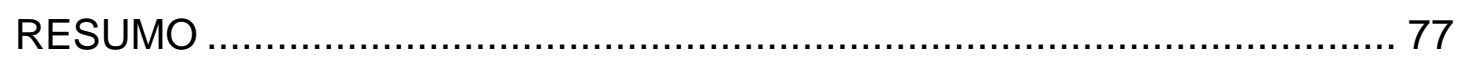

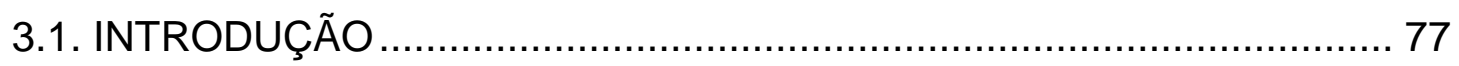

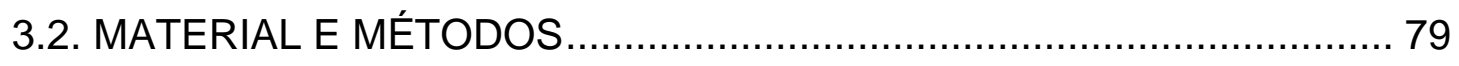

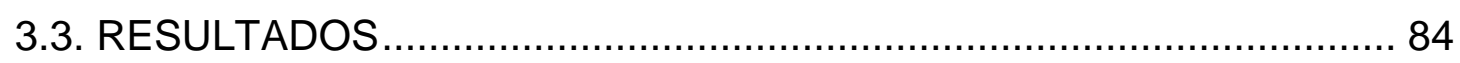

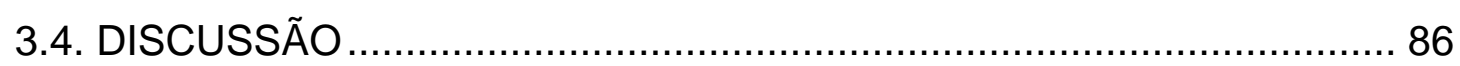

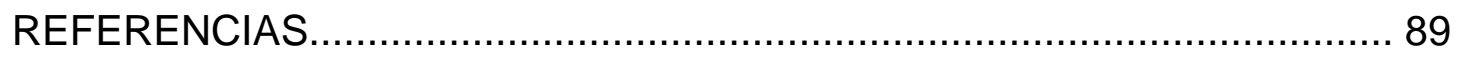

CAPÍTULO IV - EFEITO DA MELATONINA NA EXPRESSÃO DE GENES ASSOCIADOS A PROCESSOS BIOLÓGICOS EM CÉLULAS DO CUMULUS: UMA ANÁLISE DE TRANSCRIÇÃO GÊNICA …......................................... 92

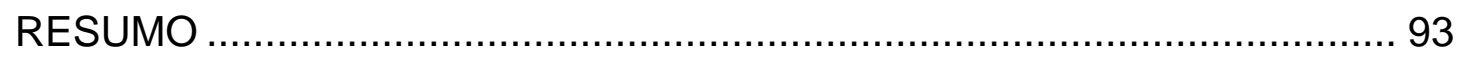

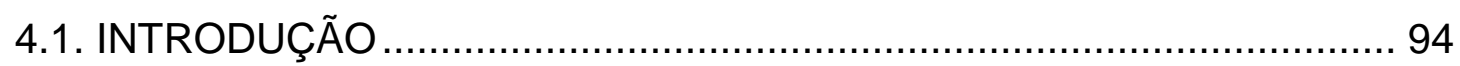

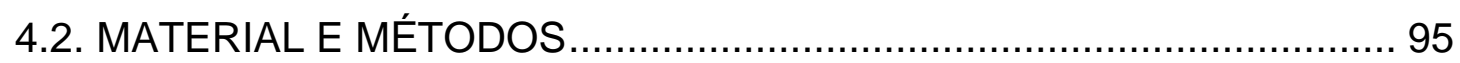

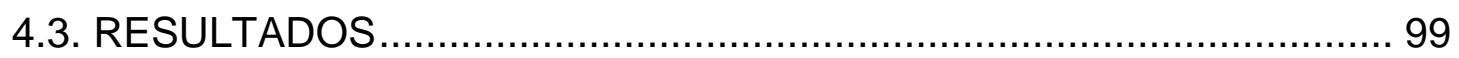

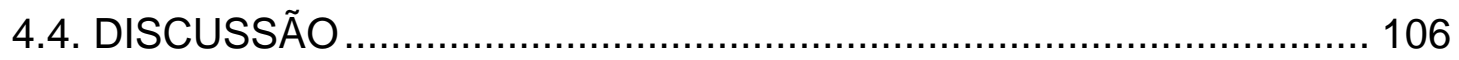

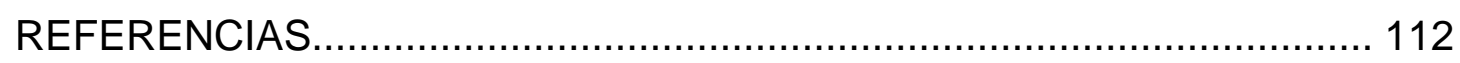

CAPÍTULO $V$ - O EFEITO DA MELATONINA SOBRE A EXPRESSÃO DE GENES EM CÉLULAS DO CUMULUS ASSOCIADOS À VIABILIDADE OOCITÁRIA: UMA ANÁLISE DE TRANSCRIÇÃO GÊNICA........................ 119

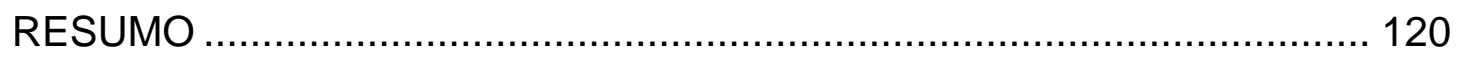

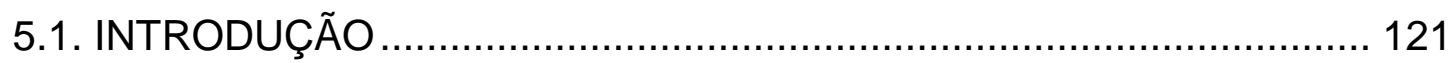

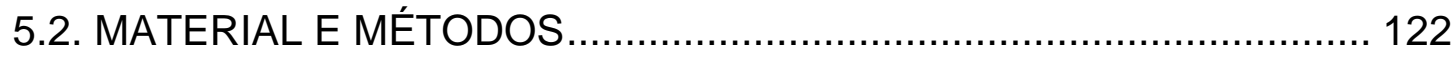

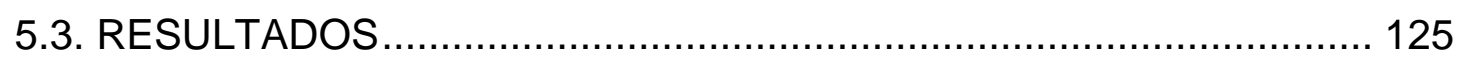

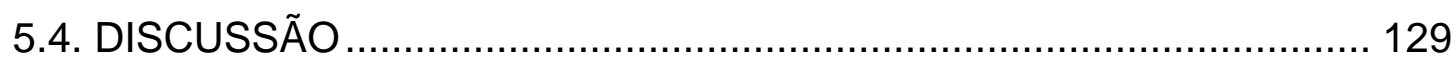

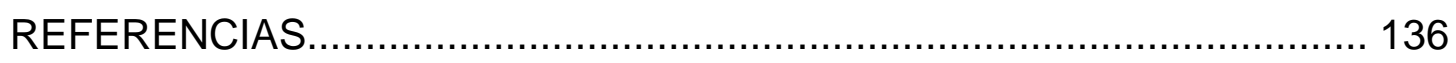


INTRODUÇÃO E REVISÃO DE

LITERATURA 


\section{INTRODUÇÃO}

A melatonina ( $\mathrm{N}$-acetil-5-metoxitriptamina) foi isolada a partir da glândula pineal bovino há mais de 50 anos (LERNER et al., 1958, 1959). A melatonina é uma indolamina sintetizada a partir de triptofano em diversos tecidos e tipos celulares, embora sua maior produção ocorra na glândula pineal. A melatonina é um antioxidante muito eficaz e protege as células contra o estresse oxidativo causado pelas espécies reativas e a sua natureza anfifílica the permite atravessar todos as barreiras morfofisiológicas (REITER, 2000; TAN et al., 2002; HARDELAND et al., 2011).

Como antioxidante, a melatonina protege o DNA nuclear e mitocondrial, ácidos graxos e proteínas dos danos induzidos por radicais livres (REITER et al., 2000). Os efeitos citoprotetores da melatonina e dos seus derivados estão relacionados com as propriedades antioxidantes diretas (TAN et al., 1993, GALANDO et al., 2013) e indiretas (BARLOW; WALDEN et al., 1995; FISCHER et al., 2013). As atividades diretas da melatonina e de seus metabólitos envolvem a neutralização das ROS (espécies reativas de oxigênio) e RNS (espécies reativas de nitrogênio) (TAN et al., 1993; CHEN et al., 2013). Indiretamente, a melatonina estimula enzimas anti-oxidantes e inibe as próoxidativas (REITER et al., 2002; RODRIGUEZ et al., 2004), provavelmente através de mecanismos epigenéticos (KORKMAZ et al., 2012); no entanto, os mecanismos e vias pelas quais essa indolamina age, ainda permanecem pouco esclarecidos.

Em oócitos e células do cumulus, tal como em outras células, os derivados tóxicos de oxigênio e nitrogênio são importantes mediadores de sinalização intracelular responsáveis por várias funções durante os processos fisiológicos normais (NASR-ESFAHANI; JOHNSON, 1991). As ROS aumentam o potencial de desenvolvimento durante a maturação dos oócitos (MORADO et al., 2009), em especial na retomada da meiose de oócitos pré-ovulatórios mamíferos (TRIPATHI et al., 2009).

Notoriamente, as células germinativas de mamíferos são altamente sensíveis aos danos causados pelo extresse oxidativo, particularmente, durante as técnicas artificiais de reprodução (SOMFAl et al., 2007; ALI et al., 2003), o que resulta em baixa viabilidade oocitária e, consequentemente, 
baixas taxas de desenvolvimento embrionário (KHALIL et al., 2013). Na espécie suína, a maturação in vitro (MIV) de oócitos tem apresentado limitações adicionais. Os oócitos suínos são altamente vulneráveis aos radicais livres e ao estresse oxidativo devido, ao menos em parte, aos seus níveis significativamente elevados de lipídios citoplasmáticos (GADJA et al., 2009).

Embora os lipídios sejam componentes estruturais e fonte de energia fundamental para o desenvolvimento normal do oócito, níveis elevados de lipídios citoplasmáticos comprometem o sucesso das técnicas de reprodução assistida (STURMEY et al., 2009). A combinação entre o aumento das ROS, especialmente desenvolvimento durante a maturação oocitária, e sua alta afinidade pelos lipídios, resulta em danos moleculares como consequência do estresse oxidativo (GOUD et al., 2008).

A capacidade da melatonina em neutralizar as ROS e RNS, reduzir as concentrações de peróxidos lipídicos de lesões do DNA a torna uma alternativa para promover melhorias na viabilidade das células germinativas e embrionárias (NAKANO et al., 2012; VARGAS et al., 2011; WANG et al., 2013). Estudos recentes têm demonstrado que a administração exógena de melatonina resulta em neutralização direta de radicais livres, entretanto, quando em baixa dosagem ocorre uma ação indireta, ou seja, a melatonina age promovendo aumento na síntese de enzimas antioxidantes (CARPENTIERI et al., 2012). A regulação da expressão de genes pela melatonina é dependente da síntese de novas proteínas, pois com o uso da cicloheximida, um inibidor da síntese de proteica, é inibido o aumento de RNAm após a administração de melatonina (RODRIGUEZ et al., 2004).

Em relação a maturação oocitária, a melatonina tem se mostrado benéfica na promoção da maturação de oócitos em diferentes espécies (RODRIGUEZOSORIO et al., 2007; MANJUNATHA et al., 2009; CASÃO et al., 2010; ELRAEY et al., 2011). Na espécie suína em especial, a adição da melatonina ao meio de maturação, resultou em melhoria da qualidade do oócito e número de oócitos que atingiram a metáfase II (CHOI et al., 2008; KANG et al., 2009; SHI et al., 2009). Entretanto poucos trabalhos relatam a ação da melatonina sobre outros processos biológicos, além de regulação do ciclo celular, apoptose e metabolismo oxidativo. 
Desta forma, nossa hipótese é de que a melatonina: 1) estimula a maturação nuclear e citoplasmática; 2) reduz os níveis intracelulares de ROS durante a maturação; 3) influencia positivamente na expressão dos genes antioxidantes no oócitos e nas células do cumulus e, 4) modula a expressão de genes associados a processos biológicos e reprodutivos em células do cumulus. 


\section{OBJETIVOS}

Objetivo geral

- $\quad$ Avaliar o efeito da melatonina sobre a maturação e os níveis de ROS em oócitos e expressão de genes associados a proteção celular de oócitos e células do cumulus suínos maturados in vitro.

\section{Objetivos específicos}

- $\quad$ Avaliar o efeito da melatonina em diferentes concetrações $\left(0,10^{-}\right.$ ${ }^{9} \mathrm{M}, 10^{-6} \mathrm{M}$ e $10^{-3} \mathrm{M}$ de melatonina) sobre a maturação oocitária in vitro nuclear e citoplasmática, em diferentes tempos de maturação (36, 40 ou 44 h);

- $\quad$ Avaliar o efeito da melatonina em diferentes concetrações $\left(0,10^{-}\right.$ ${ }^{9} \mathrm{M}$ e $10^{-6} \mathrm{M}$ de melatonina) sobre os níveis intracelulares de ROS em oócitos suínos maturados in vitro por 44 horas;

- Avaliar o efeito da melatonina $\left(10^{-9} \mathrm{M}\right)$ e da suplementeção de macromoléculas (meio definido - PVA e indefinido - pFF) durante a maturação in vitro (MIV) na proteção celular considerando-se a expressão de genes antioxidantes (SOD1, SOD2, Catalase e GPX) em oócitos suínos e suas respectivas células do cumulus;

- Avaliar o efeito da suplementação da melatonina ao meio de maturação por meio da análise do perfil de trascriptomas de células do cumulus oriundas de complexo cumulus-oócito de suínos, em processos biológicos essenciais para o funcionamento celular;

- Avaliar o efeito da melatonina sobre os genes associados à viabilidade oocitária e ao desenvolvimento embrionário subsequente por meio da análise do perfil de trascriptomas de células do cumulus oriundas de complexos cumulus-oócitos (CCOs) suínos maturados in vitro via RNA-Seq. 


\section{A MELATONINA NA REPRODUÇÃO ANIMAL}

\subsection{INTRODUÇÃO}

Durante o metabolismo celular normal são produzidas espécies reativas, que regulam as diversas funções celulares (DENNERY, 2007). No ovário, as espécies reativas de oxigênio (ROS) e as espécies reativas de nitrogênio (RNS) são geradas dentro do microambiente folicular pelo oócito e pelas células somáticas, e regulam a função ovariana através de vias moleculares e bioquímicas (DEVINE et al., 2012).

As espécies reativas, no entanto, são compostos químicos que tem afinidade pelas moléculas celulares complexas (proteínas, lipídios e DNA), modificando suas funções principais e promovendo danos moleculares como consequência do estresse oxidativo (GOUD et al., 2008). Desde modo, é provável que o dano oxidativo induzido pelas espécies reativas desempenhem um papel importante no desenvolvimento de transtornos que influenciam significativamente na fertilidade da fêmea (TAMURA et al., 2009).

A melatonina (N-acetil-5-metoxitriptamina), foi isolada a partir da glândula pineal bovino há mais de 50 anos (LERNER et al., 1958, 1959). A produção rítmica de melatonina pela glândula pineal foi inicialmente ligada à regulação da reprodução sazonal em espécies fotoperiódicas (HOFFMAN; REITER, 1965; REITER; FRASCHINI, 1969). Porém, estudos posteriores mostraram que as funções da melatonina excedem em muito a de regulação da competência reprodutiva sazonal (TAN et al., 1993; CAJOCHEN et al., 2003; CALVO et al., 2013; MAURIZ et al., 2013; PROIETTI et al., 2013).

A melatonina é um antioxidante muito eficaz e protege as células contra o estresse oxidativo causado pelas espécies reativas e a sua natureza anfifílica Ihe permite atravessar todas as barreiras morfofisiológicas (REITER, 2000; TAN et al., 2002; HARDELAND et al., 2011). Além disso, os metabólitos da melatonina são igualmente eficazes ou até superiores à molécula progenitora na neutralização de reagentes à base de oxigênio e nitrogênio (TAN et al., 2002; GALANO et al., 2013).

Os efeitos citoprotetores da melatonina e dos seus derivados estão relacionados com as propriedades antioxidantes diretas (TAN et al., 1993, 
GALANDO et al., 2013) e indiretas (BARLOW; WALDEN et al., 1995; FISCHER et al., 2013). As atividades diretas da melatonina e de seus metabólitos envolvem a neutralização das ROS e RNS (TAN et al., 1993; CHEN et al., 2013), enquanto que indiretamente, a melatonina estimula enzimas antioxidantes e inibe enzimas pró-oxidativas (REITER et al., 2002; RODRIGUEZ et al., 2004), provavelmente através de mecanismos epigenéticos (KORKMAZ et al., 2012).

Os gametas e embriões de mamíferos são particularmente vulneráveis ao estresse oxidativo (SOMFAl et al., 2007; ALI et al., 2003; KHALIL et al., 2013), devido à composição da membrana plasmática, à presença de altos níveis de lipídios citoplasmáticos e exposição a mudanças dramáticas no microambiente, especialmente durante 0 uso de técnicas artificiais de reprodução (MATACAMPUZANO et al., 2012; TAMURA et al., 2009).

A melatonina tem a capacidade de neutralizar espécies ROS e RNS nestas células, reduzir as concentrações de peróxidos lipídicos, as lesões do DNA e, assim, melhorar a viabilidade das células germinativas e embrionárias (NAKANO et al., 2012; VARGAS et al., 2011; WANG et al., 2013). A melatonina, portanto, é uma molécula que pode ser utilizada na produção in vitro de embriões para melhorar a qualidade do oócito, viabilizar a fertilização e, consequentemente, proporcionar taxas de prenhez satisfatórias.

\subsection{Importância fisiológica das espécies reativas}

As espécies reativas são compostos químicos altamente reativos que podem ser ou não radicais livres (TAMURA et al., 2009), ou seja, moléculas ou partes destas que possuam um ou mais elétrons desemparelhados em sua órbita externa (HALLIWELL, 2012). As espécies reativas são geralmente resultantes do metabolismo celular normal ou são produzidos após a exposição a moléculas tóxicas ou a processos que promovem estresse oxidativo (FUJIMOTO et al., 2011).

No entanto, apesar de suas ações destrutivas, estas espécies desempenham papéis importantes como segundos mensageiros, em funções celulares por meio da ativação das cascatas de sinalização celular, como as 
que envolvem a ativação das proteínas cinases por mitógenos e a regulação dos fatores de transcrição (DENNERY, 2007).

Em condições patológicas, as espécies reativas contribuem para 0 estresse oxidativo, isto é, situações em que há um grave desequilíbrio entre a produção de espécies reativas e o sistema de defesa antioxidante (GOMES et al., 2012). O aumento das espécies reativas é prejudicial à viabilidade das células, uma vez que estes reagentes são altamente nocivos à principais moléculas celulares (proteínas, lipídios e DNA), sendo inclusive capazes de alterar as suas funções (GOUD et al., 2008).

Existem vários tipos de ROS e RNS. Os ROS mais conhecidos são íon radical superóxido $\left(\mathrm{O}_{2}{ }^{-}\right)$, peróxido de hidrogênio $\left(\mathrm{H}_{2} \mathrm{O}_{2}\right)$, radical hidroxila $\left({ }^{\circ} \mathrm{OH}\right)$, e radical peroxil (ROO); enquanto que os RNS mais comuns são o óxido nítrico $\left(\mathrm{NO}{ }^{*}\right)$, nitrito $\left(\mathrm{NO}_{2}{ }^{\circ}\right)$, nitrato $\left(\mathrm{NO}_{3}{ }^{-}\right)$e o ânion peroxinitrito (ONOO$\left.{ }^{-}\right)$(BASHAN et al., 2009). Devido à sua elevada reatividade, estes derivados podem ser devastadores para outras moléculas podendo causar disfunção celular e, por vezes, a morte celular (REITER et al., 1997).

A síntese fisiológica das ROS é associada a uma variedade de respostas intracelulares a partir da ativação transcricional como a proliferação celular e a apoptose (FORMAN; TORRES, 2002). As alterações de óxido-redução causadas pelas ROS podem modular as atividades das cinases e fosfatases, as quais estão envolvidas na cascata de transdução de sinais intracelulares e, regulam a forma como as células reagem ao ambiente (LI et al., 2001).

As ROS também são mediadores de fatores de crescimento e citocinas, que regulam as cascatas de sinalização e a atividade das proteínas (BRIGELIUS-FLOHE et al., 2004). Na função de segundos mensageiros, as ROS regulam fatores de transcrição (NF-kB e p38 MAP cinase; DENNERY, 2007; KHALIL et al 2013) e genes que codificam enzimas antioxidantes (GUPTA et al., 2006; BONNEFONT-ROUSSELOT; COLLIN, 2010).

Nos organismos aeróbicos mais de $95 \%$ de $\mathrm{O}_{2}$ inalado é utilizado para a produção de ATP na mitocôndria e o restante é quimicamente reduzido a $\mathrm{O}_{2}{ }^{--}$ (GUTTERIDGE; HALLIWELL, 2000; REITER et al, 2000.). Na cadeia de transporte de elétrons, há uma série de transportadores de elétrons agrupados em quatro complexos enzimáticos: Complexo I (NADH ubiquinonaredutase); complexo II (succinatoredutaseubiquinona); complexo III (ubiquinolcitocromo $\mathrm{C}$ 
redutase) e complexo IV (citocromo C oxidase) (LEONet al., 2004). O produto final da cadeia respiratória é a $\mathrm{H}_{2} \mathrm{O}$, que é gerada a partir de uma redução de quatro elétrons de $\mathrm{O}_{2}$ pelo complexo IV (NOHL et al. 2005).

O sistema de transferência de elétrons nas mitocôndrias é claramente uma das principais fontes de $\mathrm{O}_{2} \cdot{ }^{-}$devido à fosforilação oxidativa na face citoplasmática da membrana mitocondrial interna (CADENAS; DAVIES, 2000). $\mathrm{O}_{2}{ }^{--}$modula as concentrações estáveis das espécies reativas tanto dentro da matriz mitocondrial quanto no citoplasma (MARTINO et al., 2012).

$\mathrm{O} \mathrm{O}_{2}{ }^{--}$também se difunde através da membrana e é convertido na mitocôndria em uma ROS mais estável, o $\mathrm{H}_{2} \mathrm{O}_{2}$, sendo que durante esta etapa é requerida a enzima superóxido-dismutase (SOD1 e SOD2) (KOWALTOWSKI; VERCESI, 1999). $\mathrm{O} \mathrm{H}_{2} \mathrm{O}_{2}$ regula a função celular através da ativação das proteínas cinases ativadas por mitógenos, e inibe a fosfatase, provavelmente pela oxidação direta de cisteína (KHALIL et al 2013). A reação de $\mathrm{H}_{2} \mathrm{O}_{2}$ com $\mathrm{O}_{2}{ }^{\circ-}$ é de grande importância fisiológica uma vez que gera $0^{\circ} \mathrm{OH}$, uma espécie altamente reativa (GOUD et al 2008.).

$\mathrm{O} \cdot \mathrm{OH}$ é um componente altamente tóxico e pode ser gerado tanto pela reação de Haber-Weiss como pela reação de Fenton (RAHA, ROBINSON, 2000) durante o metabolismo energético celular na cadeia mitocondrial de transporte de elétrons (DAVERMANN et al., 2002). $\mathrm{O} \cdot \mathrm{OH}$ é altamente destrutivo e pode modificar as purinas e pirimidinas, por adição de ligações duplas nas bases do DNA ou pela remoção de um átomo de hidrogênio a partir do grupo metil de timina e de cada uma das ligações $\mathrm{C}$-H da desoxirribose, resultando em danos no DNA (COOKE et al., 2003; AGARWAL et al., 2005).

\subsection{Melatonina: biossíntese e liberação em mamíferos}

A melatonina é uma indolamina com um peso molecular de $232 \mathrm{kDa}$, sintetizada a partir de triptofano, na glândula pineal (SUGDEN, 1989). Adicionalmente, muitos órgãos, tecidos e células (cérebro, trato gastrointestinal, testículos, ovário, medula espinal, linfócitos, retina, córnea e pele) também tem a capacidade de produzir melatonina (REITER et al., 2013a). No entanto, o ritmo circadiano da melatonina no sangue se deve exclusivamente à sua secreção pela glândula pineal (REITER et al., 2010). 
A via biossintética da melatonina pineal, que é presumivelmente semelhante em outros órgãos, começa com a conversão de triptofano em 5hidroxitriptofano através da ação da 5-triptofano hidroxilase (Fig. 1); os pinealócitos retiram o 5-hidroxitriptofano sangue e o convertem em serotonina através de hidroxilação seguida por descarboxilação (TAMURA et al., 2009). Subsequentemente, a serotonina é convertida em $\mathrm{N}$-acetilserotonina através de uma reação de acetilação pela enzima arilalquilamina $\mathrm{N}$-acetiltransferase (AANAT) (IUVONE et al., 2005). Finalmente, a enzima acetilserotonina Ometiltransferase (ASMT) catalisa a reação de metilação formando a melatonina (STEHLE et al., 2011).

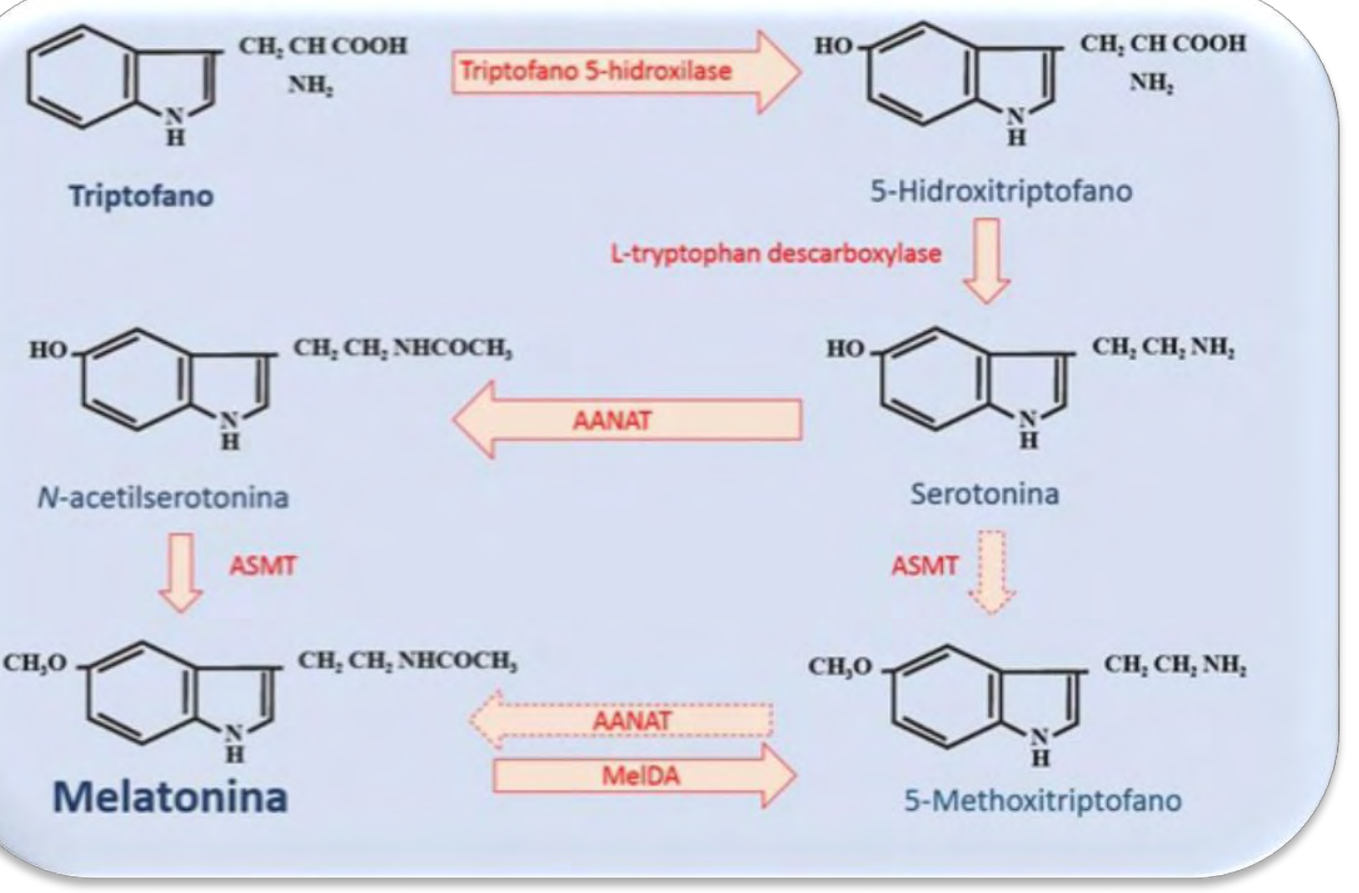

Figura 1. As vias biossintéticas clássicas da melatonina em animais vertebrados. 5-triptofano hidroxilase, L-triptofano descarboxilase; AANAT, arilalquilamina $\mathrm{N}$-acetiltransferase; ASMT, acetilserotonina O-metiltransferase; MeIDA, melatonina desacetilase. A linha tracejada representa uma via de menor importância da biossíntese da melatonina (TAN et al., 2012, modificado).

Uma vez formada, a melatonina é liberada nos capilares que penetram na glândula pineal e, posteriormente, a melatonina é distribuída a todas as células do organismo. O ciclo diário de luz e escuro influencia significativamente a 
síntese da melatonina pela pineal com base na mudança de duração do fotoperíodo ambiental (LINCOLN; SHORT, 1980; REITER, 1993).

Estudos recentes têm mostrado que a melatonina é possivelmente, sintetizada também no ovário. A concentração de melatonina no fluido folicular varia de acordo com a espécie e o tamanho do folículo. Em suínos a concentração de melatonina aumenta medida em que ocorre o crescimento folicular (SHI et al., 2009), na espécie humanos é reduzida (NAKAMURA et al., 2003), enquando que em bovinos parece não sofrer influência (Coelho et al., 2012; Tian et al., 2014).

Em extratos de ovários foi identificada a presença de precursores de melatonina ( $\mathrm{N}$-acetilserotonina e serotonina) bem como atividade das enzimas AANAT e ASMT, as quais são essenciais para a síntese da melatonina (ITOH et al., 1999). A presença de serotonina nas células da granulosa e oócitos sugere que poderia ocorrer síntese local de melatonina, e se assim for, eliminar radicais livres e estimular essas células a produzir hormônios esteroides sexuais (AMIREAULT; DUBÉ, 2005). A possibilidade da síntese da melatonina por parte do complexo cumulus-oócito foi também sugerida em vacas (ELRAEY et al., 2011) e em mulheres (KIM et al., 2013). No entanto, há poucas informações sobre o mecanismo exato pelo qual a melatonina age na proteção celular do complexo cumulus-oócito.

\subsection{Receptores de melatonina e seus processos de transdução e sinalização}

A melatonina tem uma multiplicidade de ações nas células, algumas das quais envolvem receptores enquanto outras são independentes dos mesmos (REITER et al., 2007). Os mecanismos de sinalização dos receptores de melatonina são muito complexos e variam com o tipo de célula e, eventualmente, com a espécie animal (Reiter et al, 2013).

A melatonina influencia a fisiologia celular através de receptores de membrana (MT1 e MT2) e sítios de ligação nuclear (RZR e ROR) seguido da interação deste com moléculas citosólicas, como a calmodulina (REITER et al., 2010). Ambos os receptores MT1 e MT2 (Fig. 2) foram amplamente estudados 
e as suas funções fisiológicas e propriedades farmacológicas estão bem documentadas (DUBOCOVICH; MARKOWSKA, 2005).

MT1 e MT2 pertencem à família dos receptores acoplados à proteína G, embora tenham estruturas moleculares e propriedades farmacológicas distintas (CHEN et al., 2013). Estes dois receptores estão ligados à ativação de várias vias de sinalização, sendo a inibição da formação de AMPc a via mais comum (DUBOCOVICH, 2007). A cascata de transdução do sinal associada com a ativação de MT1 ou MT2 em células alvo muitas vezes resulta na inibição da atividade da enzima adenilato-ciclase (VON GALL et al., 2002).

Um terceiro local de ligação da melatonina, inicialmente denominado MT3, pertence a um grupo de redutases que estão envolvidas na proteção contra o estresse oxidativo, evitando a transferência de elétrons por meio das reações das quinonas (CHEN et al., 2013). Sabe-se que o receptor MT3 está localizado no citoplasma (Fig. 2), no entanto, a cascata de transdução de sinal do receptor da MT3 ainda não foi identificada (TAN et al., 2007).

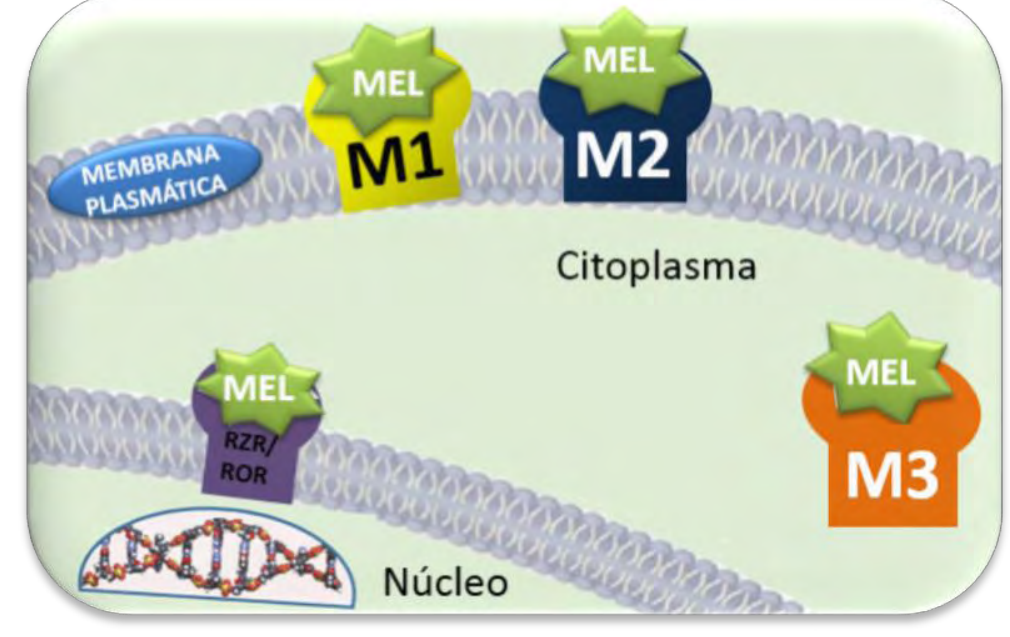

Figura 2. Receptores de membrana (MT1 e MT2), receptor de citoplasma (MT3) e sítios de ligação nuclear (RZR/ROR) de melatonina.

Os receptores MT1 estão localizados no ovário (YONEl et al., 2010), bem como em outros tecidos como, por exemplo, no núcleo supraquiasmático (DUBOCOVICH; MARKOWSKA, 2005) e nas células de Leydig (FRUNGIERI et al., 2005). Os receptores MT2 são expressos nas células da granulosa, e embora se apresentem de forma mais restrita, são detectados principalmente no cérebro, e também encontrados nos tecidos do miométrio e testículo 
(DUBOCOVICH; MARKOWSKA, 2005). Os receptores MT3, por sua vez, foram encontrados no ovário e oócito, bem como em tecidos de fígado, rim e cérebro (NOSJEAN et al., 2000; VINCENT et al., 2010; SAMPAIO et al., 2012).

Algumas das ações da melatonina são mediadas através de receptores de membrana específicos, enquanto outros contam com sítios de ligação nuclear, sendo que estes últimos correspondem aos membros da superfamília dos receptores órfãos do ácido retinóico (RZR/ROR). A superfamília de receptores nucleares já conta com cerca de 200 membros, cuja maioria é considerada como órfã, ainda que os ligantes para alguns deles já tenham sido identificados (SMIRNOV, 2001).

\subsection{Propriedades antioxidantes da melatonina}

Em mamíferos com fotoperíodo, a melatonina age no eixo hipotalâmicohipofisário-gonadal para induzir a reprodução sazonal (REITER; FRASCHININ, 1969; BARRETT; BALBOREA, 2012). A melatonina, adicionalmente, é um poderoso antioxidante e agente anti-apoptótico, que devido à sua capacidade de neutralizar diretamente os derivados tóxicos de oxigênio e reduzir a formação de espécies reativas, previne a ocorrência de danos oxidativos e nitrosativos nas macromoléculas em todos os órgãos e células (REITER, 2000; TAN et al., 2002; HARDELAND et al., 2011).

Em contraste com outros antioxidantes que são hidrofílicos ou lipofílicos, a melatonina é anfifílica de forma que atravessa todas as barreiras morfofisiológicas, estando em condições de reduzir o dano oxidativo e nitrosativo tanto em ambientes celulares lipídicos como aquosos (REITER et al., 2004) em todas as células (REITER et al., 2013a). Em um estudo recente, a melatonina mostrou ser melhor protetor contra danos oxidativos que antioxidantes sintéticos, como por exemplo, MitoE e MitoQ (LOWES et al., 2013).

Como antioxidante, a melatonina protege o DNA nuclear e mitocondrial, ácidos graxos e proteínas dos danos induzidos por radicais livres (REITER et al., 2000). Além disso, esta indolamina tem a capacidade de desintoxicar uma ampla variedade de ROS e RNS. Adicionalmente, os metabólitos da melatonina formados quando esta age como um neutralizador de espécies 
reativas são também eficazes, ou em alguns casos, até mais eficazes que a melatonina na desintoxicação de derivados prejudiciais do oxigênio (GALANO et al., 2013).

\subsubsection{Neutralização direta de radicais livres}

A elevada capacidade da melatonina como um agente redox é devida em grande parte à presença de um anel aromático rico em elétrons, o qual funciona como um doador de elétrons (TAN et al., 1993; ÇELIK; NAZIROĞLU, 2012). A melatonina também influencia positivamente a função do complexo mitocondrial I e IV (MARTIN et al., 2000), por meio da atenuação da fuga de elétrons e da geração resultante do $\mathrm{O}_{2}{ }^{--}$e do aumento da eficiência da fosforilação oxidativa, o que resulta em redução do estresse oxidativo (LEON et al., 2005; HARDERLAND, 2005).

As propriedades citoprotetoras da melatonina estão também associadas à sua capacidade em manter a estabilidade das membranas celulares através da inibição da peroxidação lipídica (GARCIA et al., 1992). A melatonina e os seus metabólitos, por meio do que é conhecido como cascata antioxidante, fornecem proteção contínua à célula através da eliminação de radicais livres (TAN et al., 2002), o que se traduz em proteção antioxidante em todos os tecidos e órgãos (MUCHERJEE et al., 2012; NANERJEEJ et al., 2012; CAVALENTE DE MATOS et al., 2012).

A melatonina e seus metabólitos neutralizam tanto ROS quanto RNS, como por exemplo, ${ }^{\circ} \mathrm{OH}, \mathrm{H}_{2} \mathrm{O}_{2},{ }^{1} \mathrm{O}_{2}$ e ONOO- (TAN et al., 2000; REITER et al., 2002; CHEN et al., 2013). Vários metabólitos da melatonina são efetivos para reduzir o estresse oxidativo causado por essas espécies reativas (TAN et al., 2001; GALANO et al., 2013), sendo o AFMK (N1-acetil-N2-formil-5metoxiquinuramina) e o $\mathrm{AMK}$ (N-acetil-5-metoxiquinuramina), que são sintetizados durante a desintoxicação das espécies reativas pela melatonina, os mais conhecidos (LEON et al., 2004; GALANO et al., 2013).

O AFMK é um membro da família kynuramine, gerada a partir de melatonina por via enzimática ou por via oxidativa (TAN et al., 2000; HARDELAND et al., 2009; NIU et al., 2010). O AFMK interage diretamente com as ROS na proteção do DNA e dos lipídios neutralizando os radicais livres por 
meio de um mecanismo que envolve a quelação de metais de transição (TAN et al., 2001; RESSMEYER et al, 2003).

O AFMK forma AMK via clivagem do anel pirrol, fazendo com que este se torne um neutralizador de radicais livres mais eficiente que o AFMK ou a melatonina (RESSMEYER et al., 2003; REITER et al., 2007). O AMK reduz as ROS através de um mecanismo não-competitivo pela ligação com $\mathrm{Ca}^{2+}$ calmodulina e interage com as RNS gerando AMMC (3-acetoamidomethil6-methoxicinnolinona) e AMNK (N1-acetil-5-metoxi-3-nitrokynuramine); esses metabólitos do AMK são produzidos sob pressão oxidativa aumentada ou condições de estresse oxidativo (GUENTHER et al., 2005).

\subsubsection{Neutralização indireta de radicais livres}

Estudos recentes têm demonstrado que a administração exógena de melatonina resulta em neutralização direta de radicais livres, entretanto, quando em baixa dosagem ocorre uma ação indireta, ou seja, a melatonina age promovendo aumento na síntese de enzimas antioxidantes (CARPENTIERI et al., 2012).

O papel de antioxidante indireto da melatonina refere-se à estimulação das enzimas anti-oxidantes e inibição de enzimas pró-oxidantes tais como oxidase de NADPH e as lipoxigenases (BARLOW WALDEN et al., 1995; REITER et al., 2002; RODRIGUEZ et al., 2004), possivelmente através de mecanismos epigenéticos (KORKMAZ et al., 2012). A melatonina age em nível mitocondrial reduzindo os danos moleculares, uma vez que limita desacoplamento das proteínas mitocondriais e a perda de elétrons da cadeia respiratória na membrana mitocondrial interna (HARDERLAND, 2004; TAN et al, 2013). A ação específica da melatonina na mitocôndria é consistente com os seus altos níveis nessa organela (VENEGAS et al., 2013).

A regulação da expressão de genes pela melatonina é dependente da síntese de novas proteínas, pois com o uso da cicloheximida, um inibidor da síntese de proteica, impede o aumento de RNAm após a administração de melatonina (RODRIGUEZ et al., 2004). Além disso, a melatonina também promove a síntese de novo de glutationa, estimulando a sua atividade de síntese da enzima ligasegluatamilcisteína (URATA et al., 1999). 


\subsection{Dano oxidativo e efeito protetor da melatonina no ovário}

Espécies reativas, tanto ROS e RNS, estão proeminentemente envolvidas na regulação da função ovariana e podem desempenhar papel crítico no desenvolvimento de doenças que afetam de forma significativa a fertilidade da fêmea. No microambiente ovariano, as células somáticas foliculares e o oócito são as possíveis fontes de ROS (AGARWAL et al., 2005), as quais regulam a maturação do oócito, a foliculogênese, a esteroidogênese e a luteólise (MARTIN-ROMERO et al., 2008; ZHANG et al., 2009).

Assim como as ROS, as RNS influenciam no desenvolvimento do ovário e na sua fisiologia durante a puberdade (SRIVASTAVA et al., 1997). Estudos sugerem que o NO altera a fisiologia reprodutiva (ZAMBERLAM et al., 2011; FERREIRA-DIAS et al., 2011), sendo que de forma direta regula a secreção pulsátil de $\mathrm{GnRH}$ no hipotálamo (KAISER et al., 1996), modulando o comportamento sexual (MANI et al., 1994) e, de forma indireta, inibe a esteroidogênese das células da granulosa luteinizadas (VAN VOORHIS et al., 1994).

Sob condições patológicas, as reações oxidativas contribuem para 0 estresse oxidativo nos gametas, resultando em mutações de inativação ou perda do DNA mitocondrial e da síntese e da acumulação de proteínas anormais ou oxidadas (GOUD et al., 2008), o que é prejudicial para as células (DAVERMANN et al., 2002). O aumento excessivo das ROS e sua difusão através do citoplasma causa efeitos negativos em vários processos celulares (ÇELIK; NAZIROĞLU, 2012). A toxicidade das RNS parece estar particularmente associada com a geração de $\mathrm{ONOO}^{-}$de $\mathrm{NO}^{\cdot} \mathrm{e} \mathrm{O}_{2}{ }^{--}$; $\mathrm{ONOO}^{-}$, os quais são apontados como causa de diversas condições fisiopatológicas, como inflamação e câncer (BONNEFONT-ROUSSELOT; COLLIN, 2010).

Assim, considerando que as espécies reativas induzem danos oxidativos no folículo e oócito e que a melatonina e os seus metabolitos têm enorme capacidade de eliminação desses radicais livres, muitos estudos têm investigado a eficácia da melatonina em proteger as células da granulosa e oócitos dos danos causados pelo estresse oxidativo (CARLOMAGNO et al., 2011; REITER et al., 2013b). 
No ovário de mamífero, como em outros órgãos, os receptores de melatonina tanto da membrana quanto nucleares foram identificados. Algumas das ações da melatonina no ovário provavelmente envolvem os receptores de membrana convencionais (VINCENT et al., 2010; REITER et al., 2013a; TAMURA et al, 2013). Os receptores de melatonina foram identificados nas células da teca e da granulosa, e por serem encontrados tanto em folículos maduros quanto em células de luteinizadas, indicam que a melatonina atua diretamente sobre a fisiologia do ovário (YONEI et al., 2010).

A melatonina parece ter funções variadas dentro do ovário, incluindo sua ação sobre a esteroidogênese folicular pela modulação de AMPc e, consequentemente, a expressão da proteína reguladora esteroidogênica aguda (StAR), a qual é expressa nas células da teca e da granulosa (Fig. 3); na mitocôndria, a proteína StAR é responsável pelo transporte de colesterol para a membrana interna onde a maioria das enzimas envolvidas na esteroidogênese está localizada (TAMURA et al., 2009).

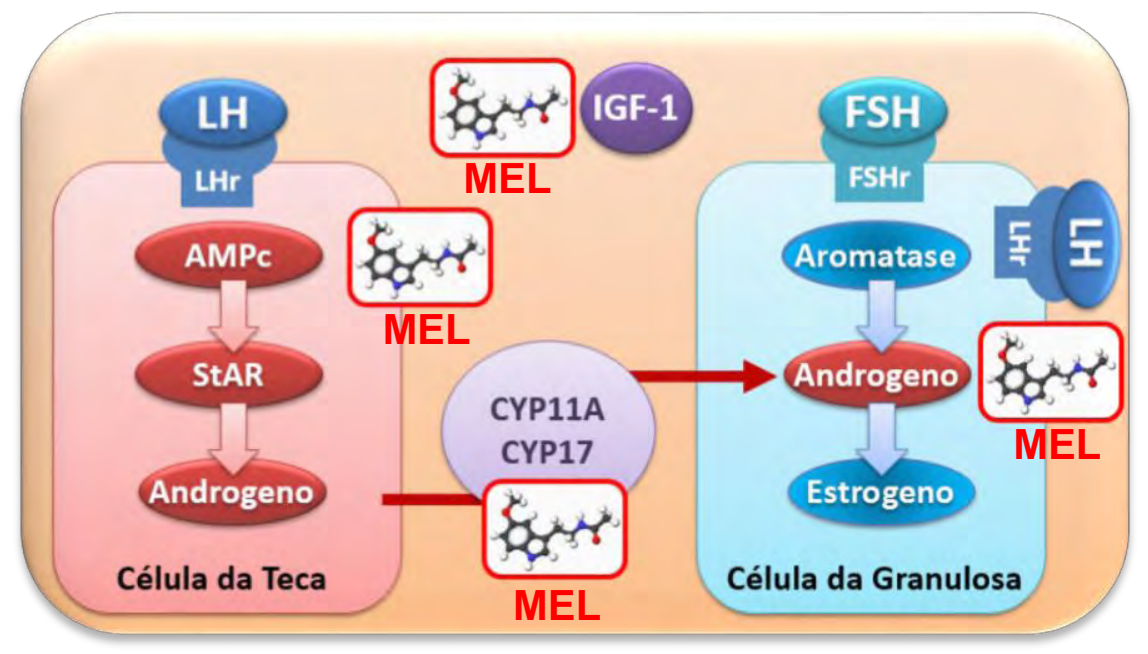

Figura 3. Via de regulação da melatonina sobre a esteroidogênese. A Melatonina (MEL) parece modular AMPc, genes associdados ao IGF-1, Receptor de LH e a expressão dos genes CYP11A e CYP17.

\subsubsection{Estresse oxidativo e efeito da melatonina no folículo}

Os mecanismos de proteção contra o estresse oxidativo, tais como aumento da atividade da SOD e/ou da glutationa (GSH), controlam o equilíbrio 
entre as ROS e os antioxidantes dentro do folículo, o que parece ser essencial para a manutenção do oócito e das células da granulosa (TAMURA et al., 2012). As ROS são geradas pelas células esteroidogenicamente ativas, incluindo as células da granulosa dos folículos antrais, as quais apresentam elevado metabolismo energético (RAPOPORT et al., 1995). A geração das ROS e RNS no microambiente folicular pelo oócito e pelas células somáticas, é responsável pela regulação de vias moleculares e bioquímicas necessárias para a foliculogênese (TAMURA et al., 2009; DEVINE et al., 2012).

Grande quantidade de ROS acompanhada por níveis reduzidos de enzimas antioxidantes (por exemplo, a SOD, GPX e Catalase) pode contribuir para a ocorrência de apoptose, mediada pelo estresse oxidativo nos folículos atrésicos (HALLIWELL et al., 1988; GUPTA et al., 2006). A atresia é um processo de apoptose que é marcadamente influenciado por fatores pró- e antiapoptóticos como consequência do estresse oxidativo (ZHANG et al., 2006).

O papel da mitocôndria na regulação da apoptose como consequência da liberação de citocromo c e outras proteínas pró-apoptóticas, tem sido documentado em diversos estudos (MATIKAINEN et al., 2001; OTT et al., 2002). Uma vez liberado no citosol, o citocromo $c$ ativa as pró-caspases (caspase-3 e caspase 9), desencadeando a cascata apoptótica (MATIKAINEN et al., 2001, TAMURA et al., 2009). Os membros da família Bcl2 são importantes para o processo de atresia de folículos antrais, devido à regulação da clivagem e liberação do citocromo c, haja vista que a super-expressão do gene BCL2 em células da granulosa de folículos em crescimento reduz a apoptose (Fig. 4) (HSU et al., 1996). 


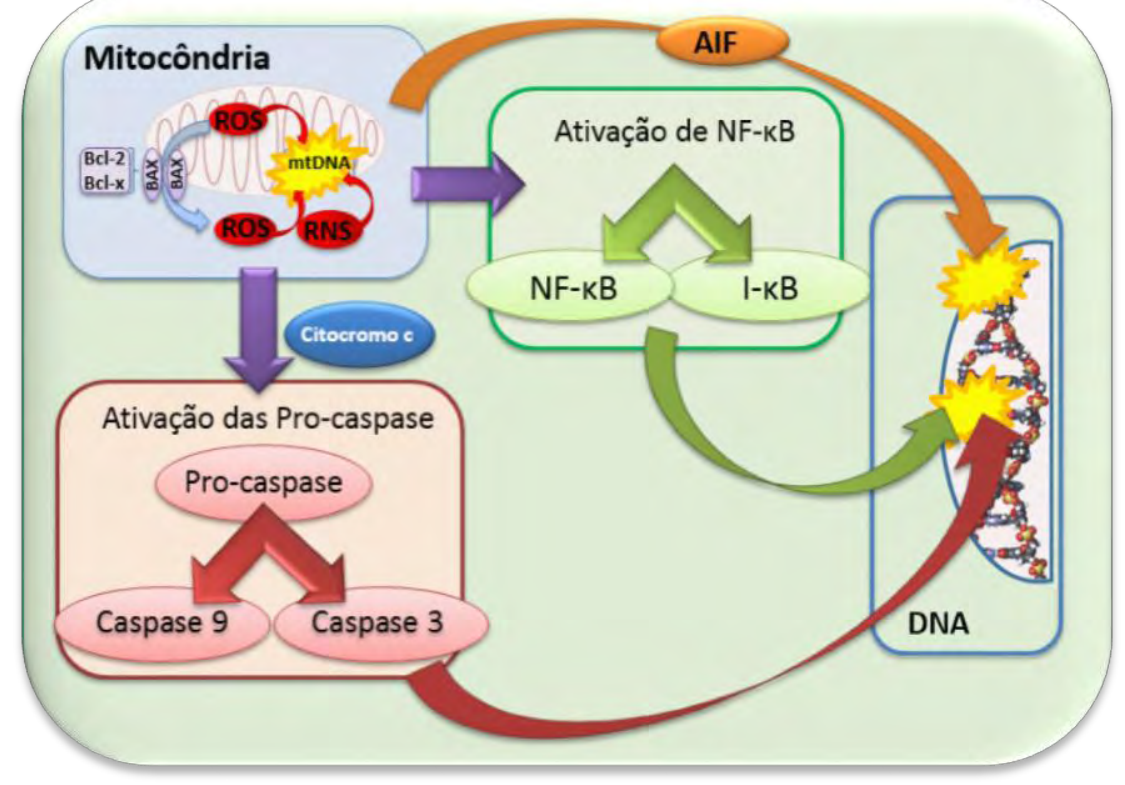

Figura 4. Danos ao DNA induzidos por espécies reativas de oxigênio e espécies reativas de nitrogênio via cascata de apoptose. ROS = espécies reativas de oxigênio; RNS = espécies reativas de nitrogênio; AIF = fator indutor de apoptose.

Os níveis de ROS regulam positivamente a liberação do fator indutor de apoptose (AIF), que é um importante meio de regulação da apoptose (NORBERG et al., 2010). Os baixos níveis de NO• são acompanhados por um aumento da produção de $\mathrm{H}_{2} \mathrm{O}_{2}$, modulado pela taxa de consumo de $\mathrm{O}_{2}{ }^{--}$por meio da citocromo c oxidase (SÄRKELÄ et al., 2001).

Os níveis de melatonina no fluido folicular (FF) ovariano é, significativamente mais elevada que no plasma, quando mensurada simultaneamente nos dois fluidos (BRZEZINKI et al., 1987, TAMURA et al., 2012). A concentração intrafolicular de melatonina é presumivelmente mantida tanto pelo transporte ativo de melatonina a partir do sangue como pela sua síntese local (CARLOMAGNO et al., 2011). Embora ainda não exista estudos em suínos, Coelho et al. (2013) e Tian et al. (2015) detectaram a presença de AMPK e AFMK em fluido folicular bovino, corroborando assim a teoria de síntese ovariana.

Em ovários suínos a concetração de melatonina varia de acordo com o estágio folicular (SHI et al., 2009). Acredita-se que o aumento da concentração de melatonina no folículo em crescimento seja um importante fator para evitar a atresia (TAMURA et al., 2009), uma vez que a melatonina reduz a apoptose 
das células, permitindo que os folículos pré-ovulatórios se desenvolvam plenamente e forneçam oócitos maduros para a ovulação (TAMURA et al., 2008a; REITER et al., 2013).

Embora muitos estudos tenham demostrado que a melatonina é capaz de impedir a apoptose em células normais (SAINZ et al., 2003; LIU et al., 2012) e induzir este processo em células cancerosas (MIN et al., 2012; SÁNCHEZHIDALGO et al., 2012), o mecanismo exato através do qual a melatonina interfere no processo de apoptose não está totalmente esclarecido (LIU et al., 2012).

A melatonina também aumenta a síntese do GSH (URATA et al., 1999), a atividade da SOD (LIU; NG, 2000), assim como impede a indução da via mitocondrial intrínseca da apoptose através da indução de expressão de Bcl2 e redução da atividade de caspase-3, o que contribui para a proteção das células contra o estresse oxidativo e ainda regula a proliferação celular (MOLPECERES et al., 2007).

\subsubsection{Estresse oxidativo e o efeito da melatonina no oócito}

Em oócitos, tal como em outras células, os derivados tóxicos de oxigênio e nitrogênio são importantes mediadores de sinalização intracelular responsáveis por várias funções durante os processos fisiológicos normais (NASR-ESFAHANI; JOHNSON, 1991). As ROS aumentam o potencial de desenvolvimento durante a maturação dos oócitos (MORADO et al., 2009), em especial na retomada da meiose de oócitos pré-ovulatórios mamíferos (TRIPATHI et al., 2009). Em oócitos envelhecidos, $\mathrm{O}_{2}{ }^{--}$é produzido em abundância na mitocôndria por causa da perda de elétrons de alta energia da cadeia de transporte de elétrons, o que, inevitavelmente, eleva o dano oxidativo dessas células (CUI et al., 2011).

De forma semelhante ao que ocorre com as ROS, o NO• gerado por células somáticas ou foliculares desempenha papel importante na maturação e fisiologia dos oócitos. O NO• é gerado por um grupo de enzimas, incluindo as NOS nos ovários de mamíferos (AGARWAL et al., 2005).

Os íons metálicos de transição, como ferro e cobre, são capazes de catalisar a redução de $\mathrm{H}_{2} \mathrm{O}_{2}$ pela $\mathrm{O}_{2}{ }^{-}$, resultando assim em ${ }^{\circ} \mathrm{OH}$ e ${ }^{1} \mathrm{O}_{2}(\mathrm{RAHA}$; 
ROBINSON, 2000). Sob condições fisiológicas, nem $\mathrm{H}_{2} \mathrm{O}_{2}$ Ou O $\mathrm{O}_{2}{ }^{--}$isoladamente reagem com bases de DNA induzindo a quebra da cadeia sem que os íons metálicos estejam presentes no sistema (NACKERDIEN et al., 1992).

Em condições patológicas, o aumento das ROS e RNS com subsequente estresse oxidativo acelera o envelhecimento do oócito e provoca a deterioração da qualidade oocitária (YANG et al., 1998; GOUD et al., 2008). As reações oxidativas induzem a oxidação de bases, o que afeta a estrutura primária do DNA dos oócitos (MENEZO et al, 2010), e ao mesmo tempo, alteram a composição lipídica da membrana e aumentam o $\mathrm{Ca}^{2+}$ citosólico (GOUD et al., 2008; TAMURA et al., 2009). O Ca ${ }^{2+}$ causa disfunção da cadeia respiratória que por sua vez promove alterações estruturais da membrana mitocondrial interna, elevando a geração de ROS (KOWALTOWSKI; VERCESI, 1999).

Diversos estudos têm revelado a capacidade da melatonina de evitar a fragmentação do DNA e da modulação da liberação do citocromo c na mitocôndria (REITER et al., 2000; MARTIN et al, 2000; 2002; de LEON et al., 2005). Também há evidências de que a melatonina reduz a concentração citosólica de $\mathrm{Ca}^{2+}$ livre, bem como inibe a apoptose subsequente evocada por $\mathrm{H}_{2} \mathrm{O}_{2}$ (ÇELIK; NAZIROĞLU, 2012). Além disso, existe uma correlação direta entre as concentrações de melatonina no FF e a qualidade do oócito; a melatonina também contribui para que o folículo pré-ovulatório desenvolva plenamente um oócito adequado para a fertilização (TAMURA et al., 2009). A adição de melatonina exógena ao meio de cultivo, em combinação com $\mathrm{H}_{2} \mathrm{O}_{2}$, protege os oócitos contra o estresse oxidativo induzido pelo $\mathrm{H}_{2} \mathrm{O}_{2}$, melhorando assim, a maturação oocitária de forma dose-dependente (TAMURA et al., 2008b).

A melatonina também apresenta efeitos protetores durante a ovulação, uma vez que o desprendimento do oócito do folículo de Graaf envolve processo semelhante à resposta inflamatória local na parede folicular (ESPEY et al., 1994). Como consequência, são produzidas espécies reativas em excesso pelas células inflamatórias no local, aumentando a probabilidade de que 0 oócito enfrente dano oxidativo.

Os lipídios desempenham papéis biológicos significativos nos processos metabólicos das células, servindo como uma fonte de energia e "blocos estruturais" para as membranas dos organismos; entretanto, os oócitos dos 
mamíferos são particularmente vulneráveis ao estresse oxidativo por possuírem altos níveis de lipídios facilmente oxidáveis (STURMEY et al., 2009). A oxidação dos ácidos graxos poli-insaturados por radicais livres em sistemas biológicos pode ser causada por qualquer espécie reativa capaz de remover um átomo de hidrogênio $\left(\mathrm{H}^{\cdot}\right)$ a partir de um grupo metileno $\left(-\mathrm{CH}_{2}\right)$ (GUTTERIDGE, 1995).

As ROS reagem aleatoriamente com lipídios, o que pode iniciar 0 processo de peroxidação lipídica (Fig. 5), a qual é caracterizada por uma reação em cadeia que produz várias moléculas de degradação incluindo o malonaldeído (MDA) e 4-hidroxialkenal (HNE) (ESTERBAUER et al., 1991). A peroxidação lipídica causa perda de fluidez e diminuição da resistência elétrica da membrana celular (RICHTER, 1987), comprometendo gravemente a sua função, sendo que os metais de transição (ferro e cobre) auxiliam na iniciação desse processo de peroxidação (KITAMURA et al., 2005).

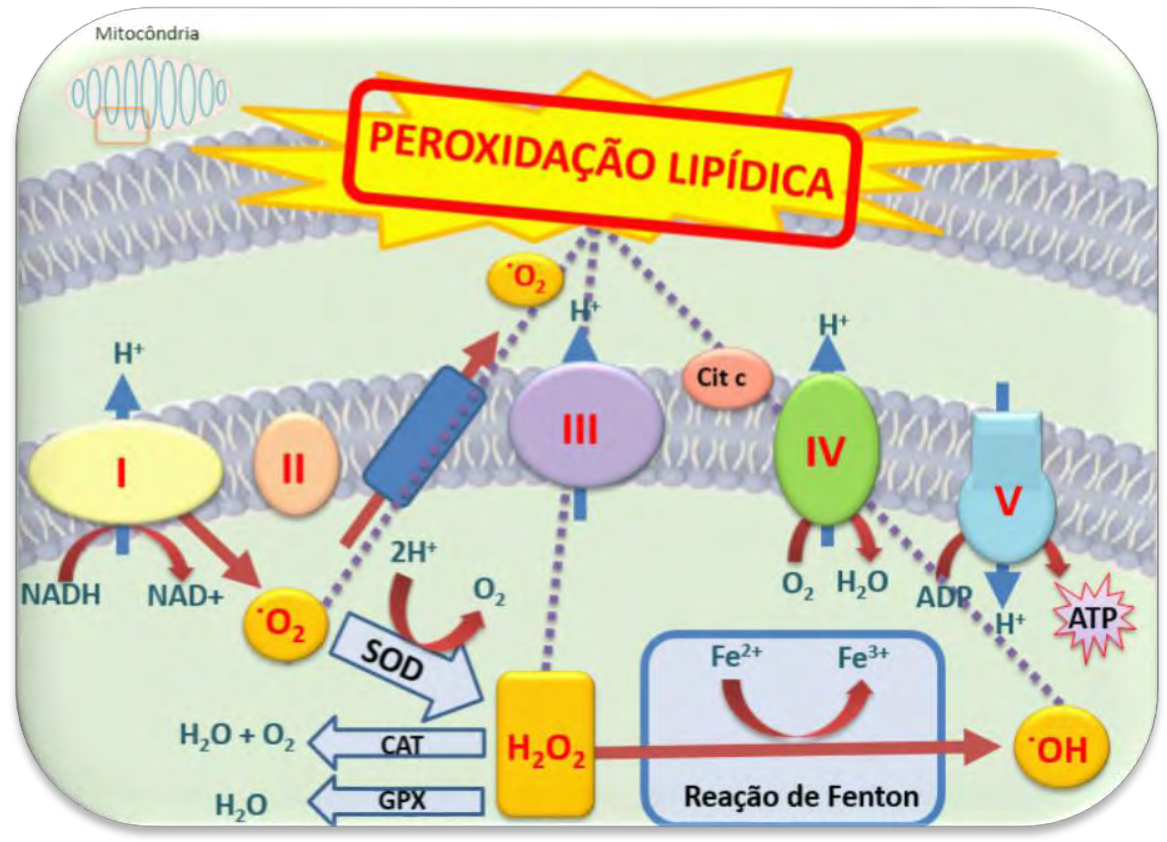

Figura 5. Peroxidação lipídica na membrana mitocondrial induzida por espécies reativas de oxigênio. $\mathrm{O}_{2}{ }^{--}=$íon superóxido; $\mathrm{SOD}=$ superóxido dismutase; $\mathrm{CAT}=$ Catalase; $\mathrm{GPX}=$ glutationaperoxidase; $\mathrm{H}_{2} \mathrm{O}_{2}=$ peróxido de hidrogênio; $\mathrm{Cit} \mathrm{c}=$ Citochormo $\mathrm{c} ;{ }^{\cdot} \mathrm{OH}=$ radical hidroxila.

As $\mathrm{ROS}\left({ }^{\circ} \mathrm{OH}, \mathrm{O}_{2}{ }^{\cdot-}\right.$ e $\left.\mathrm{H}_{2} \mathrm{O}_{2}\right)$ produzidas dentro do folículo, especialmente durante o processo ovulatório, são conhecidas por serem prejudiciais para o 
oócito (TAMURA et al., 2012), uma vez que podem ser associadas com modificações em proteínas essenciais na manutenção da integridade de várias organelas e citoesqueleto; tais alterações podem afetar a organização e distribuição mitocondrial, bem como a atividade celular (GOUD et al., 2008). As proteínas celulares são altamente vulneráveis ao ataque oxidativo a partir de intermediários de radicais de peroxidação lipídica, por causa do seu grande tamanho, e ainda devido ao fato de alguns deles estarem intimamente associados com metais de transição (STADTMAN, 1992).

A capacidade da melatonina e dos seus metabólitos em proteger as proteínas através da redução de danos oxidativos e nitrosativos tem sido documentada (TAN et al., 2002; HARDELAND et al., 2011). Recentemente, alguns estudos evidenciaram que a melatonina exógena diminui a oxidação de proteínas, equilibrando o estado oxidante-antioxidante (KORKMAZ et al., 2012; DKHAR; SHARMA, 2013). Sob condições de estresse oxidativo, ocorre rápida queda de melatonina acompanhada por aumentos nos níveis de seus metabólitos, por exemplo, AFMK e AMK (TAN et al., 2007). Os níveis fisiológicos de AMK mostram ser altamente protetores contra a destruição oxidativa da proteína (REITER et al, 2007).

\subsubsection{A melatonina e a maturação oocitária in vitro}

O importante papel desempenhado pela melatonina na promoção da maturação do oócito tem sido documentado em diferentes espécies (ADRIAENS et al., 2006, DIMITRIADIS et al., 2005, BAHADORI et al., 2013, RODRIGUEZ- OSORIO et al., 2007; MANJUNATHA et al., 2009; CASÃO et al., 2010; EL-RAEY et al., 2011). A suplementação de melatonina no meio de maturação reduz os níveis das ROS (NAKANO et al., 2012), protege as células do cumulus de danos no DNA (TAKADA et al., 2012), promove a maturação nuclear (KANG et al, 2009, AHN e BAE, 2004, NA et al, 2005) e citoplasmática (EL-RAEY et al., 2011) e consequentemente a viabilidade do oócito (SHI et al., 2009, BERLINGUER et al. 2009). Embora, Adriaens et al., 2006 e Casao et al. 2010 tenha sugerido que o efeito da melatonina sobre a maturação do oócito é dose-dependente, 0 efeito benéfico pelo qual a melatonina favorece a 
maturação in vitro, está associado à sua habilidade de redução das ROS (BERLINGUER et al., 2009).

Em adição, as células do cumulus de mamíferos desempenham um papel fundamental no crescimento e maturação oocitária, fazendo com que a expansão das células do cumulus seja considerado um indicador de desenvolvimento oocitário (QIAN et al, 2003). Estudos tem mostrado que a melatonina tem efeito significativo sobre o grau de expansão das células do cumulus em bovinos (EL-RAEY et al., 2011) e suínos (KANG et al., 2009).

Na espécie suína, a melatonina também tem sido utilizada com o objetivo de melhorar a maturação in vitro de oócitos (KANG et al., 2009; SHI et al., 2009). A suplementação do meio de maturação oocitária in vitro com melatonina $(10 \mathrm{ng} / \mathrm{ml})$ resultou em um maior percentual de oócitos em metáfase Il e uma porcentagem significativamente superior de blastocistos, embora sem efeitos sobre as taxas de clivagem e o número de células do blastocisto (KANG et al., 2009). Entretanto, Shi et al. (2009) utilizando suplementação simultânea de melatonina (10-9 M) no meio de maturação e no meio de cultivo obtiveram melhores taxas de clivagem e de blastocisto.

Em oócitos bovinos maturados in vitro, a suplementação de melatonina (10-9 M) influencia na transição nuclear da fase de MI para MII, na expansão das células do cumulus e na dispersão das mitocôndrias no citoplasma, resultando em aumento da taxa de maturação nuclear (EL-RAEY et al., 2011). Em um estudo recente, utilizando melatonina em nanocápsulas lipídicas durante a MIV, Remião et al., 2016 reportaram melhoria na viablidade de oócitos bovinos maturados in vitro, de forma superior a ação da melatonina não encapsulada. $O$ efeito benéfico da melatonina é provavelmente mediada por receptores, uma vez que estudos indicam que a melatonina aumenta a expressão relativa de genes associdados à expansão do cumulus (PTX3 e HAS1/2) e maturação oocitária (GDF9 e MARF1) (TIAN et al., 2014).

Em búfalos, a suplementação da melatonina ao meio de maturação melhorou significativamente a taxa de maturação nuclear oocitária, reduzindo o estresse oxidativo, a concentração de peróxido de hidrogênio e os danos no DNA (MANJUNATHA et al., 2009). E na espécie ovina, a adição de melatonina na concentração de 10-6 M em meios de maturação e fertilização in vitro resultou em aumento nas taxas de maturação in vitro e taxas de clivagem 
(CASAO et al., 2010). Enquanto que em caprinos, embora a suplementação in vivo com melatonina ( $3 \mathrm{mg}$ ) tenha influenciado na taxa de maturação in vitro, promoveu aumento na taxa de clivagem e no desenvolvimento embrionário subsequente (BERLINGUER et al., 2009).

A presença de melatonina $(50-500 \mathrm{pg} / \mathrm{ml})$ pode também promover a maturação de oócitos de murinos, uma vez que acelera a quebra da vesícula germinativa e no desenvolvimento de embriões de ratos (BAHADORI et al., 2013). E de acordo com Ishizuka et al., (2000), melatonina na concentração de 10-6 M melhora a viabilidade oocitária, favorecendo a fertilização e o desenvolvimento embrionário subsequente. Além disso, também promove a melhoria na qualidade complexos cumulus-oócitos provenientes de ovários murinos após o processo de vitrificação/descongelamento (HEMADI et al., 2009).

Estudos em peixes, demonstraram que a pré-incubação de oócitos com melatonina influencia a ação do fator promotor da maturação (MPF), que age durante a quebra da vesícula germinativa sobre a ruptura do envelope nuclear do oócito (TOKUMOTO et al., 2004; CHATTORAJ et al., 2005).

Em humanos a melatonina tem sido utilizada como uma ferramenta para melhorar a qualidade de oócitos, durante a maturação in vitro, uma vez que protege diretamente o oócito contra o estresse oxidativo (TAKASAKI et al., 2003, TAMURA et al., 2008). A suplementação do meio de maturação com melatonina favorece a maturação citoplasmática de oócitos imaturos humanos e melhora os resultados clínicos subsequentes (KIM et al., 2013).

\section{REFERÊNCIAS}

AGARWAL, A., GUPTA, S., SHARMA, R.K. Role of oxidative stress in female reproduction. Reproductive Biology and Endocrinology 3;28, 2005.

ALI, A.A., BILODEAU, J.F., SIRARD, M.A. An antioxidant requirement for bovine oocytes varies during in vitro maturation, fertilization and development. Theriogenology, v. 59, p. 939-949, 2003.

AMIREAULT, P., DUBÉ, F. Serotonin and its antidepressant-sensitive transporter in mouse cumulus-oocyte complexes and embryo. Biology of Reproduction, v. 773, p. 358-365, 2005. 
BARLOW-WALDEN, L.R., REITER, R.J., ABE, M., PABLOS, M., MENENDEZ-PELAEZ, A., CHEN, L.D., POEGGELER, B. Melatonin stimulates brain glutathione peroxidase activity. Neurochemistry International, v. 26, p. 497-502, 1995.

BARRETT, P.,BOLBOREA, M. Molecular pathways involved in seasonal body weight and reproductive responses governed by me latonin. Journal of Pineal Research, v. 52, p. 376-388, 2012.

BASHAN, N., KOVSAN, J., KACHKO, I., OVADIA, H., RUDICH, A. Positive and Negative Regulation of Insulin Signaling by Reactive Oxygen and Nitrogen Species. Physiological Reviews, v. 89, p. 27-71, 2009.

BONNEFONT-ROUSSELOT, D., COLLIN, F. Melatonin: Action as antioxidant and potential applications in human disease and aging. Toxicology, v. 278, p. 55-67, 2010.

BRIGELIUS-FLOHE, R., BANNING, A., KNY, M., BOL, G.F. Redox events in interleukin-1 signaling. Archives of Biochemistry and Biophysics, v. 423, p. 66-73, 2004.

CADENAS, E., DAVIES, K.J. Mitochondrial free radical generation, oxidative stress, and aging. Free Radical Biology and Medicine, v. 29, p. 222-230, 2000.

CAJOCHEN, C., KRÄUCHI, K., WIRZ-JUSTICE, A. Role of melatonin in the regulation of human circadian rhythms and sleep. Journal of NeuroEndocrinology, v. 15, p. 432-437, 2003.

CALVO, J.R., GONZÁLEZ-YANES, C., MALDONADO, M.D. The role of melatonin in the cells of the innate immunity: a review. Journal of Pineal Research, 55, 103-120, 2013.

CARPENTIERI, A., DÍAZ DE BARBOZA, G., ARECO, V., PERALTA LÓPEZ, M., TOLOSA DE TALAMONI, N. New perspectives in melatonin uses. Pharmacological Research, v. 65, p. 437-44, 2012.

CASAO, A., ABECIA, J.A., CEBRIAN PEREZ, J.A., MUIÑO-BLANCO, T., VÁZQUEZ, M.I., FORCADA, F. The effects of melatonin on in vitro oocyte competence and embryo development in sheep. Spanish Journal of Agricultural Research, v. 8, p. 35-41, 2010.

ÇELIK, O., NAZIROĞLU, M. Melatonin modulates apoptosis and TRPM2 channels in transfected cells activated by oxidative stress. Physiology and Behavior, v. 107, p. 458-465, 2012.

CHEN, Y.C., SHEEN, J.M., TIAO, M.M., TAIN, Y.L., HUANG, L.T. Roles of melatonin in fetal programming in compromised pregnancies. International Journal of Molecular Sciences, v. 6, p. 5380-5401, 2013. 
CHOI, J., PARK, S.M., LEE, M., KIM, J.H., JEONG, Y.I., LEE, J.Y., PARK, S.W., KIM, H.S., HOSSEIN, M.S., JEONG, Y.W., KIM, S., HYUN, S.H., HWANG, W.S. Anti-apoptotic effect of melatonin on porcine parthenogenic embryos. Molecular Human Reproduction, v. 75, p. 1127-1135, 2008.

COOKE, M.S., EVANS, M.D., DIZDAROGLU, M., LUNEC, J. Oxidative DNA damage: mechanisms, mutation, and disease. The FASEB Journal, v. 17, p. 1195-1214, 2003.

CUI, M.S., WANG, X.L., TANG, D.W., ZHANG, J., LIU, Y., ZENG, S.M. Acetylation of $\mathrm{H} 4 \mathrm{~K} 12$ in porcine oocytes during in vitro aging: potential role of ooplasmic reactive oxygen species. Theriogenology, v. 75, p. 638-646, 2011.

DAVERMANN, D., MARTINEZ, M., MCKOY, J., PATEL, N., AVERBECK, D., MOORE, C.W. Impaired mitochondrial function protects against free radicalmediated cell death. Free Radical Biology and Medicine, v. 33, p. 12091220, 2002.

DE LEON, P.M., CAMPOS, V.F., CORCINI, C.D., SANTOS, E.C., RAMBO, G., LUCIA, T. JR, DESCHAMPS, J.C., COLLARES, T. Cryopreservation of immature equine oocytes, comparing a solid surface vitrification process with open pulled straws and the use of a synthetic ice blocker.Theriogenology, v. 77, p. 21-27, 2012.

DE MATOS CAVALCANTE, A.G., DE BRUIN, P.F., DE BRUIN, V.M., NUNES, D.M., PEREIRA, E.D., CAVALCANTE, M.M., ANDRADE, G.M. Melatonin reduces lung oxidative stress in patients with chronic obstructive pulmonary disease: a randomized, double-blind, placebo-controlled study. Journal of Pineal Research, v. 53, p. 238-244, 2012.

DENNERY, P.A. Effects of oxidative stress on embryonic development. Birth Defects Research Part C: Embryo Today, v. 81, p. 155-162, 2007.

DEVINE, P.J., PERREAULT, S.D., LUDERER, U. Roles of reactive oxygen species and antioxidants in ovarian toxicity. Biology of Reproduction, v. 86, p. 27, 2012.

DUBOCOVICH, M.L. Melatonin receptors: Role on sleep and circadian rhythm regulation. Sleep Medicine, v. 8, p. 34-42, 2007.

DUBOCOVICH, M.L., MARKOWSKA, M. Functional MT1 and MT2 melatonin receptors in mammals. Endocrine, v.27, p. 101-110, 2005.

EL-RAEY, M., GESHI, M., SOMFAI, T., KANEDA, M., HIRAKO, M., ABDELGHAFFAR, A.E., SOSA, G.A., ABAU EL-ROOS, M.E.A., NAGAI, T. Evidence of melatonin synthesis in the cumulus oocyte complexes and its role in enhancing oocyte maturation in vitroin cattle. Molecular Reproduction and Development, v.78, p. 250-262, 2011. 
ESPEY, L.L. Current status of the hypothesis that mammalian ovulation is comparable to an inflammatory reaction. Biology of Reproduction, v. 50, p. 233-338, 1994.

FERREIRA-DIAS, G., COSTA, A.S., MATEUS, L., KORZEKWA, A.J., GALVÃO, A., REDMER, D.A., LUKASIK, K., SZÓSTEK, A.Z., WOCLAWEKPOTOCKA, I., SKARZYNSKI, D.J. Nitric oxide stimulates progesterone and prostaglandin E2 secretion as well as angiogenic activity in the equine corpus luteum. Domestic Animal Endocrinology, v. 40, p. 1-9, 2011.

FISCHER, T.W., KLESZCZYŃSKI, K., HARDKOP, L.H., KRUSE, N., ZILLIKENS, D. Melatonin enhances antioxidative enzyme gene expression (CAT, GPX, SOD), prevents their UVR-induced depletion, and protects against the formation of DNA damage (8-hydroxy-2'-deoxyguanosine) in ex vivo human skin. Journal of Pineal Research, v. 54, p. 303-312, 2013.

FORMAN, H.J., TORRES, M. Reactive oxygen species and cell signaling: respiratory burst in macrophage signaling. American Journal of Respiratory and Critical Care Medicine, v. 166, S4-8, 2002.

FRUNGIERI, M.B., MAYERHOFER, A., ZITTA, K., PIGNATARO, O.P., CALANDRA, R.S., GONZALEZ-CALVAR, S.I. Direct action of melatonin on Syrian hamster testes: melatonin subtype 1a receptors, inhibition of androgen production, and interaction with local corticotropin-releasing hormone system. Endocrinology, v. 146, p. 1541-1552, 2005.

FUJIMOTO, V.Y., BLOOM, M.S., HUDDLESTON, H.G., SHELLEY, W.B., OCQUE, A.J., BROWNE, R.W. Correlations of follicular fluid oxidative stress biomarkers and enzyme activities with embryo morphology parameters during in vitro fertilization. Fertility and Sterility, v. 96, p. 1357-1361, 2011.

GADJA, B. Factors and methods of pig oocyte and embryo quality improvement and their application in reproductive biotechnology. Reproductive Biology, v. 9, p. 97-112, 2009.

GALANO, A., TAN, D.X.,REITER, R.J. Melatonin as anatural ally against oxidative stress: a physicochemical examination. Journal of Pineal Research, v. 51, p. 1-16, 2011.

GALANO, A., TAN, D.X., REITER, R.J. On the free radical scavenging activities of melatonin's metabolites, AFMK and AMK. Journal of Pineal Research, v. 54, p. 245-257, 2013.

GAO, C., HAN, H.B., TIAN, X.Z., TAN, D.X., WANG, L., ZHOU, G.B., ZHU, S.E., LIU, G.S. Melatonin promotes embryonic development and reduces reactive oxygen species in vitrified mouse 2-cell embryos.Journal of Pineal Research, 52, 305-311, 2012. 
GOMES, E.C., SILVA, N.A., DE OLIVEIRA, M.R. Oxidants, Antioxidants, and the Beneficial Roles of Exercise-Induced Production of Reactive Species. Oxidative Medicine and Cellular Longevity, 2012:756132, 2012.

GOUD, A.P., GOUD, P.T., DIAMOND, M.P., GONIK, B., ABU-SOUD, H.M. Reactive oxygen species and oocyte aging: role of superoxide, hydrogen peroxide, and hypochlorous acid. Free Radical Biology and Medicine, v. 44, p. 1295-1304, 2008.

GUENTHER, A.L., SCHMIDT, S.I., LAATSCH, H., FOTSO, S., NESS, H., RESSMEYER, A.R. Reactions of the melatonin metabolite AMK (N1-acetyl-5methoxykynuramine) with reactive nitrogen species: formation of novel compounds, acetamidomethyl-6-methoxycinnolinone and 3-nitro-AMK. Journal of Pineal Research, v. 39, p. 251-260, 2005.

GUERIN P, EL MOUATASSIM S, MENEZO Y. Oxidative stress and protection against reactive oxygen species in the pre-implantation embryo and its surroundings. Human Reproduction Update, v. 7, p. 175-189,2001.

GUPTA, R.K., MILLER, K.P., BABUS, J.K., FLAWS, J.A. Methoxychlor inhibits growth and induces atresia of antral follicles through an oxidative stress pathway. Toxicological Sciences, v. 93, p. 382-389, 2006.

GUTTERIDGE, J.M. Lipid peroxidation and antioxidants as biomarkers of tissue damage. Clinical Chemistry, v. 41, p. 1819-1828, 1995.

GUTTERIDGE, J.M., HALLIWELL, B. Free radicals and antioxidants in the year 2000. A historical look to the future. Annals of the New YorkAcademy of Sciences, v. 899, p. 136-147, 2000.

HALLIWELL, B. Free radicals and antioxidants: updating a personal view. Nutrition Reviews, v. 70, p. 257-265, 2012.

HALLIWELL, B., GUTTERIDGE, J.M. Free radicals and antioxidant protection: mechanisms and significance in Toxicology and disease. Human and Experimental Toxicology, v. 7, p. 7-13, 1988.

HAO, Y., LAI, L., MAO, J., IM, G.S., BONK, A., PRATHER R.S. Apoptosis and in vitro development of preimplantation porcine embryos derived in vitro or by nuclear transfer. Biology of Reproduction, v. 69, p. 501-507, 2003.

HARDELAND, R. Antioxidative protection by melatonin: multiplicity of mechanisms from radical detoxification to radical avoidance. Endocrine, v. 27, p. 119-130, 2005.

HARDELAND, R., CARDINALI, D.P., SRINIVASAN, V., SPENCE, D.W., BROWN, G.M., PANDI-PERUMAL, S.R. Melatonin-a pleiotropic, orchestrating regulator molecule. Progress in Neurobiology, v. 93, p. 350-384, 2011. 
HARDELAND, R., TAN, D.X., REITER, R.J. Kynuramines, metabolites of melatonin and other indolaminas: the resurrection of an almost forgotten class of biogenic amines. Journal of Pineal Research, v. 47, p. 109-126, 2009.

HARDELAND, R., CARDINALI, D.P., SRINIVASAN, V., SPENCE, D.W., BROWN, G.M., PANDI-PERUMAL, S.R. Melatonin-A pleiotropic, orchestrating regulator molecule. Progress in Neurobiology, v. 93, p. 350384, 2011.

HARDELAND, R., PANDI- PERUMAL, S.R. Melatonin, a potent agent in antioxidative defense: Actions as a natural food constituent, gastrointestinal factor, drug and prodrug. Journal of Nutrition and Metabolism, v.2; 22, 2005.

HASTINGS, M.H., MAYWOOD, E.S., REDDY, A.B. Two decades of circadian time. Journal of NeuroEndocrinology, v. 28, p. 812-819, 2008.

HOFFMAN, R.A., REITER, R.J. Pineal gland: influence on gonads of male hamsters. Science, v. 148, p. 1609-1611, 1965.

HSU, S.Y., LAI, R.J., FINEGOLD, M., HSUEH, A.J. Targeted overexpression of Bcl-2 in ovaries of transgenic mice leads to decreased follicle apoptosis, enhanced folliculogenesis, and increased germ cell tumorigenesis. Endocrinology, v. 137, p. 4837-4843, 1996.

ITOH, M.T., ISHIZAKA, B., KURIBAYASHI, Y., AMEMIYA, A., SUMI, Y. Melatonin, its precursors, and synthesizing enzyme activities in the human ovary. Molecular Human Reproduction, v. 5, p. 402-408, 1999.

IUVONE, P.M., TOSINI, G., POZDEYEV, N., HAGUE, R., KLEIN, D.C., CHAURASIA, S. S. Circadian clocks, clock networks, arylalkylamine Nacetyltransferase, and melatonin in the retina. Progress in Retinal and Eye Research v. 24, p. 433-436, $2005 .$.

ISHIZUKA B, KURIBAYASHI Y, MURAI K. The effect of melatonin on in vitro fertilization and embryo development in mice. Journal of Pineal Research v. 28, p. 48-51, 2000.

KAISER, F.E., DORIGHI, M., MUCHNICK, J., MORLEY, J.E., PATRICK, P. Regulation of gonadotropins and parathyroid hormone by nitric oxide. Life Sciences, v. 59, p. 987-992, 1996.

KANE, D.J., SARAFIAN, T.A., ANTON, R., HAHN, H., GRALLA, E.B., VALENTINE, J.S., ORD, T., BREDESEN, D.E. Bcl-2 inhibition of neural death: decreased generation of reactive oxygen species. Science, v. 262, p. 12741277, 1993.

KANG, J.T., KOO, O.J., KWON, D.K., PARK, H.J., JANG, G., KONG, S.K., LEE, B.C. Effects of melatonin on in vitro maturation of porcine oocyte and expression of melatonin receptor RNA in cumulus and granulosa cells. Journal of Pineal Research, v. 46, p. 22-28, 2009. 
KATO, H., SUGINO, N., TAKIGUCHI, S., KASHIDA, S., NAKAMURA, Y. Roles of reactive oxygen species in the regulation of luteal function. Reviews of Reproduction, v. 2, p. 81-83, 1997.

KHALIL, W.A.,MAREI, W.F.,KHALID, M.Protective effects of antioxidants on linoleic acid-treated bovine oocytes during maturation and subsequent embryo development. Theriogenology, v.15, p. 161-168, 2013.

KIM, H.S., LEE, G.S., HYUN, S.H., LEE, S.H., NAM, D.H., JEONG, Y.W., KIM, S., KANG, S.K., LEE, B.C., HWANG, W.S. Improved in vitro development of porcine embryos with different energy substrates and serum. Theriogenology, v. 61, p. 1381-1393,2004.

KIM, C.H., JEON, H.M., LEE, S.Y., JEONG, E.K., JU, M.K., PARK, B.J., PARK, H.G., LIM, S.C., HAN, S.I., KANG, H.S. Role of reactive oxygen speciesdependent protein aggregation in metabolic stress-induced necrosis. International Journal of Oncology, v. 37, p. 97-102, 2010.

KIM, M.K., PARK, E.A., KIM, H.J., CHOI, W.Y., CHO, J.H., LEE, W.S., CHA, K.Y., KIM, Y.S., LEE, D.R., YOON, T.K. Does supplementation of in-vitro culture medium with melatonin improve IVF outcome in PCOS? Reproductive BioMedicine Online, v. 26, p. 22-29, 2013.

KITAMURA, Y., NISHIKAWA, A., NAKAMURA, H., FURUKAWA, F., IMAZAWA, T., UMEMURA, T., UCHIDA, K., HIROSE, M. Effects of $\mathrm{N}$ acetylcysteine, quercetin, and phytic acid on spontaneous hepatic and renal lesions in LEC rats. Toxicologic Pathology, v. 33, p. 584-592, 2005.

KORKMAZ, A., ROSALES-CORRAL, S., REITER, R.J. Gene regulation by melatonin linked to epigenetic phenomena. Gene, v.503, p. 1-11, 2012.

KOWALTOWSKI, A.J., VERCESI, A.E. Mitochondrial damage induced by conditions of oxidative stress. Free Radical Biology and Medicine, v. 26, p. 463-471, 1999.

LEON, J., ACUÑA-CASTROVIEJO, D., ESCAMES, G., TAN, D.-X., REITER, R.J. Melatonin mitigates mitochondrial malfunction. Journal of Pineal Research. 38, 1-9, 2005.

LEON, J., ACUÑA-CASTROVIEJO, D., SAINZ, R.M., MAYO, J.C., TAN, D.X., REITER, R.J. Melatonin and mitochondrial function. Life Sciences, v. 75, p. 765-790, 2004.

LERNER, A.B., CASE, J.D., TAKAHASHI, Y., LEE, Y., MORI, W. Isolation of melatonin, the pineal factor that lightens melanocytes. Journal of the American Chemical Society, v. 80, p. 2587, 1958.

LERNER, A.B., CASE, J.D., HEINZELMANN, R.V. Structure of melatonin. Journal of the American Chemical Society, v. 81, p. 6084-6085, 1959. 
LI, Q., SANLIOGLU, S., LI, S,.RITCHIE, T., OBERLEY, L., ENGELHARDT, J.F. GPX-1 gene delivery modulates NFkappaB activation following diverse environmental injuries through a specific subunit of the IKK complex. Antioxidants and Redox Signaling, v. 3, p. 415-432, 2001.

LINCOLN, G.A., SHORT, R.V. Seasonal breeding: nature's contraceptive. Recent Progress in Hormone Research, v. 36, p. 1-52, 1980.

LIU, Y., ZHANG, L., ZHANG, H., LIU, B., WU, Z., ZHAO, W., WANG, Z. Exogenous melatonin modulates apoptosis in the mouse brain induced by high-LET carbon ion irradiation. Journal of Pineal Research, v. 52, p. 47-56, 2012.

LIU, Y.X. Involvement of plasminogen activator and plasminogen activator inhibitor type 1 in spermatogenesis, sperm capacitation, and fertilization. Seminars in Thrombosis and Hemostasis, v. 33, p. 29-40, 2007.

LONERGAN, P.; MONAGHAN, P.; RIZOS, D.Effect of follicle size on bovine oocyte quality and development competence following maturation, fertilization and culture in vitro. Molecule Reproduction Development, v. 37, p. 48 -53, 1994.

LOWES, D.A., WEBSTER, N.R., MURPHY, M.P., GALLEY, H.F. Antioxidants that protect mitochondria reduce interleukin- 6 and oxidative stress, improve mitochondrial function, and reduce biochemical markers of organ dysfunction in a rat model of acute sepsis. British Journal of Anaesthesia, v. 110, p. $472-$ 480, 2013.

MALPAUX, B., VIGUIE, C., SKINNER, D.C., THIERY, A.C., PELLETIER, J., CHEMINEAU, P. Seasonal breeding in sheep: Mechanism of action of melatonin. Animal Reproduction Science, v. 42, p. 109-117, 1996.

MANJUNATHA, B.M., DEVARAJ, M., GUPTA, P.S.P., RAVINDRA, J.P., NANDI, S. Effect of taurine and melatonin in the culture medium on buffalo in vitro embryo development. Reproduction in Domestic Animals, v. 44, p. $12-$ 16, 2009.

MARONDE, E., STEHLE, J. The mammalian pineal gland: Known facts, unknown facets. Trends in Endocrinology and Metabolism, v. 18, p. 142-149, 2007.

MARTIN, M., MACIAS, M., ESCAMES, G., REITER, R.J., AGAPITO, M.T., ORTIZ, G.G., ACUÑA-CASTROVIEJO, D. Melatonin-induced increased activity of the respiratory chain complexes I and IV can prevent mitochondrial damage induced by ruthenium red in vivo. Journal of Pineal Research, v. 28, p. 242-248, 2000.

MARTIN, M., MACIAS, M., LEON, J., ESCAMES, G., KHALDY, H., ACUÑACASTROVIEJO, D. Melatonin increases the activity of the oxidative phosphorylation enzymes and the production of ATP in rat brain and liver 
mitochondria. The International Journal of Biochemistry \& Cell Biology, v. 34, p. 348-357, 2002.

MARTIN-HILDAGO, D., BARON, F.J., BRAGADO, M.J., CARMONA, P., ROBINA, A., GARCIA-MARIN, L.J., GIL, M.C. The effect of melatonin on the quality of extended boar semen after long-term storage at $17{ }^{\circ} \mathrm{C}$. Theriogenology, v. 75, p. 1550-1560, 2011.

MARTINO, N.A., LACALANDRA, G.M., FILIOLI URANIO, M., AMBRUOSI, B., CAIRA, M., SILVESTRE, F., PIZZI, F., DESANTIS, S., ACCOGLI, G., DELL'AQUILA, M.E. Oocyte mitochondrial bioenergy potential and oxidative stress: within-/between-subject, in vivo versus in vitro maturation, and agerelated variations in a sheep model. Fertility and Sterility, v. 97, 720-8.e1, 2012.

MARTIN-ROMERO, F.J., MIGUEL-LASOBRAS, E.M., DOMINGUEZARROYO, J.A., GONZALEZ- CARRERA, E., ALVAREZ, I.S. Contribution of culture media to oxidative stress and its effects on human oocytes. Reproductive BioMedicine Online, v. 17, p. 652-661, 2008.

MASON, A.O., GREIVES, T.J., SCOTTI, M.A., LEVINE, J., FROMMEYER, S., KETTERSON, E.D., DEMAS, G.E., KRIEGSFELD, L.J. Suppression of kisspeptin expression and gonadotropic axis sensitivity following exposure to inhibitory day lengths in female Siberian hamsters. Hormones and Behavior, v. 52, p. 492-498, 2007.

MATIKAINEN, T., PEREZ, G.I., ZHENG, T.S., KLUZAK, T.R., RUEDA, B.R., FLAVELL, R.A., TILLY, J.L. Caspase-3 gene knockout defines cell lineage specificity for programmed cell death signaling in the ovary. Endocrinology, v. 142, p. 2468-2480, 2001.

MAURIZ, J.L., COLLADO, P.S., VENEROSO, C., REITER, R.J., GONZÁLEZGALLEGO, J. A review of the molecular aspects of melatonin's antiinflammatory actions: recent insights and new perspectives. Journal of Pineal Research, v. 54, p. 1-14, 2013.

McEVOY, T.G., COULL, G.D., BROADBENT, P.J., HUTCHINSON, J.S., SPEAKE, B.K. Fatty acid composition of lipids in immature cattle, pig and sheep oocytes with intact zonapellucida. Journal of Reproduction and Fertility, v. 118, p. 163-170, 2000.

MÉNÉZO, Y., DALE, B., COHEN, M. DNA damage and repair in human oocytes and embryos: a review. Zygote, v. 18, p. 357-365, 2010.

MIN, K.J., KIM, H.S., PARK, E.J., KWON, T.K. Melatonin enhances thapsigargin-induced apoptosis through reactive oxygen species-mediated upregulation of CCAAT-enhancer-binding protein homologous protein in human renal cancer cells. Journal of Pineal Research, v. 53, p. 99-106, 2012. 
MISZTAL, T., ROMANOWICZ, K., BARCIKOWSKI, B. Melatonin. A modulator of the $\mathrm{GnRH} / \mathrm{LH}$ axis in sheep. Reproductive Biology, v. 2, p. 267-275, 2002.

MIYAMOTO, K., SATO, E.F., KASAHARA, E., JIKUMARU, M., HIRAMOTO, K., TABATA, H., KATSURAGI, M., ODO, S., UTSUMI, K., INOUE, M. Effect of oxidative stress during repeated ovulation on the structure and functions of the ovary, oocytes, and their mitochondria. Free Radical Biology and Medicine, v. 49, p. 674-681, 2010.

MOHSENI, M., MIHANDOOST, E., SHIRAZI, A., SEPEHRIZADEH, Z., BAZZAZ, J.T., GHAZI-KHANSARI, M. Melatonin may play a role in modulation of bax and bcl-2 expression levels to protect rat peripheral blood lymphocytes from gamma irradiation-induced apoptosis. Mutation Research. v. 739, p. 1927, 2012.

MOLPECERES, V., MAURIZ, J.L., GARCIA-MEDIAVILLA, M.V., GONZALEZ, P., BARRIO, J.P., GONZALEZ-GALLEGO, J. Melatonin is able to reduce the apoptotic liver changes induced by aging via inhibition of the intrinsic pathway of apoptosis. The Journals of Gerontology Series A: Biological Sciences and Medical Sciences, v. 62, p. 687-695, 2007.

MORADO, S.A., CETICA, P.D., BECONI, M.T., DALVIT, G.C. Reactive oxygen species in bovine oocyte maturation in vitro. Reproduction Fertility and Development, v. 21, p. 608-614, 2009.

MUKHERJEE, D., GHOSH, A.K., BANDYOPADHYAY, A., BASU, A., DATTA, S., PATTARI, S.K., REITER, R.J., BANDYOPADHYAY, D. Melatonin protects against isoproterenol-induced alterations in cardiac mitochondrial energymetabolizing enzymes, apoptotic proteins, and assists in complete recovery from myocardial injury in rats. Journal of Pineal Research, v. 53, p. 166-179, 2012.

NACKERDIEN, Z., OLINSKI, R., DIZDAROGLU, M. DNA base damage in chromatin of gamma-irradiated cultured human cells. Free Radical Research communications, v. 16, p. 259-273, 1992.

NAKAMURA, T., LIPTON, S.A. Redox regulation of mitochondrial fission, protein misfolding, synaptic damage, and neuronal cell death: potential implications for Alzheimer's and Parkinson's diseases. Apoptosis, v. 15, p. 1354-1363, 2010.

NAKAMURA, Y., TAMURA, H., TAKAYAMA, H., KATO, H. Increased endogenous level of melatonin in preovulatory human follicles does not directly influence progesterone production. Fertility and Sterility, v. 80, p. 10121016, 2003.

NAKANO, M.,KATO, Y., TSUNODA, Y. Effect of melatonin treatment on the developmental potential of parthenogenetic and somatic cell nucleartransferred porcine oocytes in vitro. Zygote, v. 20, p. 199-207, 2012. 
NASR-ESFAHANI, M.M., JOHNSON, M.H. The origin of reactive oxygen species in mouse embryos cultured in vitro. Development, v. 113, p. 160-551, 1991.

NIU, S., LI, F., TAN, D.X., ZHANG, L., IDLE, J.R., GONZALEZ, F.J., MA, X. Analysis of N1-acetyl-N2-formyl-5-methoxykynuramine/N1-acetyl-5-methoxykynuramine formation from melatonin in mice. Journal of Pineal Research, v. 49 , p. 106-114, 2010.

NOHL, H., GILLE, L., STANIEK, K. Intracellular generation of reactive oxygen species by mitochondria. Biochemical Pharmacology, v. 69, p. 719-723, 2005.

NORBERG, E., ORRENIUS, S., ZHIVOTOVSKY, B. Mitochondrial regulation of cell death: Processing of apoptosis-inducing factor (AIF). Biochemical and Biophysical Research Communications, v. 396, p. 95-100, 2010.

NOSJEAN, O., FERRO, M., COGE, F., BEAUVERGER, P., HENLIN, F.M., LEFOULON, F., FAUCHERE, J.L., DELAGRANGE, P., CANET, E., BOUTIN, J.A. Identification of the melatonin-binding site MT3 as the quinonereductase 2. The Journal of Biological Chemistry, v. 275, p. 31311-31317, 2000.

OTT, M., ROBERTSON, J.D., GOGVADZE, V., ZHIVOTOVSKY, B., ORRENIUS, S. Cytochrome $c$ release from mitochondria proceeds by a twostep process. Proceedings of the National Academy of SciencesUSA, v. 99, p. 1259-1263, 2002.

PANDEY, A.N., TRIPATHI, A., PREMKUMAR, K.V., SHRIVASTAV, T.G., CHAUBE, S.K. Reactive oxygen and nitrogen species during meiotic resumption from diplotene arrest in mammalian oocytes. Journal of Cellular Biochemistry, v. 111, p. 521-528, 2010.

PICINATO, M.C., HIRATA, A.E., CIPOLLA-NETO, J., CURI, R., CARVALHO, C.R., ANHÊ, G.F., CARPINELLI, A.R. Activation of insulin and IGF-1 signaling pathways by melatonin through MT1 receptor in isolated rat pancreatic islets. Journal of Pineal Research, v. 44, 88-94, 2008.

PIZZIMENTI, S., TOALDO, C., PETTAZZONI, P., DIANZANI, U.M., BARRERA, G. The "Two-Faced" Effects of Reactive Oxygen Species and the Lipid Peroxidation Product 4-Hydroxynonenal in the Hallmarks of Cancer. Cancers, v. 2, p. 338-363, 2010.

PROIETTI, S., CUCINA, A., REITER, R.J., BIZZARRI, M. Molecular mechanisms of melatonin's inhibitory actions on breast Cancers. Cellular and Molecular Life Sciences, v. 70, p. 2139-2157, 2013.

PTAK, A., LUDEWIG, G., KAPISZEWSKA, M., MAGNOWSKA, Z., LEHMLER, H.J., ROBERTSON, L.W., GREGORASZCZUK, E.L. Induction of cytochromes P450, caspase-3 and DNA damage by PCB3 and its hydroxylated metabolites in porcine ovary. Toxicology Letters, v. 166, p. 200-211, 2006. 
RADI, R., BECKMAN, J.S., BUCH, K.M., FREEMAN, B.A. Peroxynitrite oxidation of sulfhydryls. The Journal of Biological Chemistry, v. 266, p. 4244-4250, 1991.

RADU, M., MUNTEANU, M.C., PETRACHE, S., SERBAN, A.I., DINU, D., HERMENEAN, A., SIMA, C., DINISCHIOTU, A. Depletion of intracellular glutathione and increased lipid peroxidation mediate cytotoxicity of hematite nanoparticles in MRC-5 cells. ActaBiochimicaPolonica, v. 57, p. 355-360, 2010.

RAHA, S., ROBINSON, B.H. Mitochondria, oxygen free radicals, disease, and aging. Trends in Biochemical Sciences, v. 25, p. 502-508, 2000.

RAPOPORT, R., SKLAN, D., HANUKOGLU, I. Electron leakage from the adrenal cortex mitochondrial P450scc and P450c11 systems: NADPH and steroid dependence. Archives of Biochemistry and Biophysics, v. 317, p. 412-416, 1995.

REITER, R.J. The melatonin rhythm: Both a clock and a calendar. Expenientia, v. 49, p. 654-664, 1993.

REITER, R.J. The role of the neurohormone melatonin as a buffer against macromolecular oxidative damage. Neurochemistry International, v. 27, p. 453-460, 1995.

REITER, R.J. Melatonin: Lowering the high price of free radicals. News in Physiological Sciences, v.15, p. 246-250, 2000.

REITER, R.J., HESTER, R.J. Interrelationships of the pineal gland, the superior cervical ganglia and the photoperiod in the regulation of theEndocrinesystems ofhamsters. Endocrinology, v. 79, p. 1168-1170, 1966.

REITER, R.J., FRASCHINI, F. Endocrine aspects of the mammalian pineal gland: a review. NeuroEndocrinology, v. 5, p. 219-255, 1969.

REITER, R.J., CARNEIRO, R.C., OH, C.S. Melatonin in relation to cellular antioxidative defense mechanisms. Hormone and Metabolic Research, v. 29, p. 363-372, 1997.

REITER, R.J., TAN, D.X., MANCHESTER, L.C., QI, W. Biochemical reactivity of melatonin with reactive oxygen and nitrogen species: a review of the evidence. Cell Biochemistry and Biophysics, v. 34, p. 237-256, 2001.

REITER, R.J., TAN, D.X., MANCHESTER, L.C., EL-SAWI, M.R. Melatonin reduces oxidant damage and promotes mitochondrial respiration: implications for aging. Annals of the New YorkAcademy of Sciences, v. 959, p. 238250, 2002.

REITER, R.J., TAN, D.X., GITTO, E., SAINZ, R.M., MAYO, J.C., LEON, J., MANCHESTER, L.C., VIJAYALAXMI, KILIC, E., KILIC, U. Pharmacological 
utility of melatonin in reducing oxidative cellular and molecular damage. Polish Journal of Pharmacology, v. 56, p. 159-170, 2004.

REITER, R.J., TAN, D.X., MANCHESTER, L.C., PILAR TERRON, M., FLORES, L.J., KOPPISEPI, S. Medical implications of melatonin: receptormediated and receptor-independent actions. Advances in medical sciences, v. 52, p. 11-28, 2007.

REITER, R.J., TAN, D.X., MANCHESTER, L.C., PAREDES, S.D., MAYO, J.C., SAINZ, R.M. Melatonin and reproduction revisited. Biology of Reproduction, v.81, p. 445-456, 2009.

REITER, R.J., TAN, D.X., FUENTES-BROTO, L. Melatonin: a multitasking molecule. Progress in Brain Research, v. 181, p. 127-151, 2010.

REITER, R.J., ROSALES-CORRAL, S.A., MANCHESTER, L.C., TAN, D.X. Peripheral reproductive organ health and melatonin: ready for prime time.International Journal of Molecular Sciences, v. 14, p. 7231-7272, $2013 a$.

REITER, R.J., TAN, D.X., ROSALES-CORRAL, S., MANCHESTER, L.C. The universal nature, unequal distribution and antioxidant functions of melatonin and its derivatives. Mini Reviews in Medicinal Chemistry, v. 13, p. 373-384, 2013b.

RESSMEYER, A.R., MAYO, J.C., ZELOSKO, V., SAINZ, R.M., TAN, D.X., POEGGELER, B., ANTOLIN, I., ZSIZSIK, B.K., REITER, R.J., HARDELAND, R. Antioxidant properties of the melatonin metabolite N1-acetyl-5methoxykynuramine (AMK); scavenging of free radicals and prevention of protein oxidation. Redox Report, v. 8, p. 205-213, 2003.

REVEL, F.G., SABOUREAU, M., MASSON-PEVET, M., PEVET, P., MIKKELSEN, J.D., SIMONNEAUX, V. Kisspeptin mediates the photoperiodic control of reproduction in hamsters. Current Biology v. 16, p. 1730-1735, 2006.

RICHTER, C. Biophvsical consequences of lipid peroxidation in membranes. Chemistry and Physics of Lipids, v. 44, i75-i89, 1987.

RICHTER, C. Reactive oxygen and DNA damage in mitochondria. Mutation Research, v. 275, p. 249-255, 1992.

RIZZO, A., ROSCINO, M.T., BINETTI, F., SCIORSCI, R.L. Roles of reactive oxygen species in female reproduction. Reproduction in Domestic Animals, v. 47, p. 344-352, 2012.

RODRIGUEZ, C., MAYO, J.C., SAINZ, R.M., ANTOLIN, I., HERRERA, F., MARTIN, V., REITER, R.J. Regulation of antioxidant enzymes: A significant role for melatonin. Journal of Pineal Research, v. 36, p. 1-9, 2004. 
RODRIGUEZ-OSORIO, N., KIM, I.J., WANG, H. Melatonin increases cleavage rate of porcine preimplantation embryos in vitro. Journal of Pineal Research, v. 43 , p. $283-288,2007$

SAINZ, R.M., MAYO, J.C., RODRIGUEZ, C., TAN, D.X., LOPEZ-BURILLO, S., REITER, R.J. Melatonin and cell death: differential actions on apoptosis in normal and cancer cells. Cellular and Molecular Life Sciences, v. 60, p. 1407-1426, 2003.

SAMPAIO, R.V., CONCEIÇÃO, S., MIRANDA, M.S., SAMPAIO, L. DE F., OHASHI, O. M. MT3 melatonin binding site, MT1 and MT2 melatonin receptors are present in oocyte, but only MT1 is present in bovine blastocyst produced in vitro.Reproductive Biology Endocrinology, 3; 10:103, 2012.

SÁNCHEZ-HIDALGO, M., LEE, M., DE LA LASTRA, C.A., GUERRERO, J.M., PACKHAM, G. Melatonin inhibits cell proliferation and induces caspase activation and apoptosis in human malignant lymphoid cell lines. Journal of Pineal Research, v. 53, p. 366-373, 2012.

SARIOZKAN, S., BUCAK, M.N., TUNCER, P.B., TAŞDEMIR, U., KINET, H., ULUTAŞ, P.A. Effects of different extenders and centrifugation/washing on postthaw microscopic-oxidative stress parameters and fertilizing ability of Angora buck sperm. Theriogenology, v. 73, p. 316-323, 2010.

SARKELA, T.M., BERTHIAUME, J., ELFERING, S., GYBINA, A.A., GIULIVI, $C$. The modulation of oxygen radical production by nitric oxide in mitochondria. The Journal of Biological Chemistry, v. 276, p. 6945-6949, 2001.

SCARPELLINI, F., MASTRONE, M., SBRACIA, M., SCARPELLINI, L. Serum lipoperoxide level variations in normal and luteal phase defect cycles. Gynecologic and Obstetric Investigation, v. 42, p. 28-30, 1996.

SHAIKH, A.Y., XU, J., WU, Y., HE, L., HSU, C.Y. Melatonin protects bovine cerebral endothelial cells from hyperoxia-induced DNA damage and death. Neuroscience Letters, v. 229, p. 193-197, 1997.

SHANG, E.H., ZHDANOVA, I.V. The circadian system is a target and modulator of prenatal cocaine effects. PLoS One, v. 2, e587, 2007.

SHI, J.M., TIAN, X.Z., ZHOU, G.B., WANG, L., GAO, C., ZHU, S.E., ZENG, S.M., TIAN, J.H.,LIU, G.S. Melatonin exists in porcine follicular fluid and improves in vitro maturation and parthenogenetic development of porcine oocytes. Journal of Pineal Research, v. 47, p. 318-323, 2009.

SLIWINSKI, T., ROZEJ, W., MORAWIEC-BAJDA, A., MORAWIEC, Z., REITER, R., BLASIAK, J. Protective action of melatonin against oxidative DNA damage: chemical inactivation versus base-excision repair. Mutation Research, v. 634, p. 220-227, 2007.

SMIRNOV, A.N. Nuclear melatonin receptors. Biochemistry, v. 66, p. 19-26, 2001. 
SOMFAI, T., OZAWA, M., NOGUCHI, J., KANEKO, H., KURIANI KARJA, N.W., FARHUDIN, M., DINNYÉS, A., NAGAI, T., KIKUCHI, K.Developmental competence of in vitro-fertilized porcine oocytes after in vitro maturation and solid surface vitrification: effect of cryopreservation on oocyte antioxidative system and cell cycle. Cryobiology, v. 55, p. 115-126, 2007.

SRIVASTAVA, V.K., DISSEN, G.A., OJEDA, S.R., HINEY, J.K., PINE, M.D., DEES, W.L. Effects of alcohol on intraovarian nitric oxide synthase and steroidogenic acute regulatory protein in the prepubertal female rhesus monkey. Journal of Studies on Alcohol and Drugs, v. 68, p. 182-191, 2007.

STADTMAN, E.R. Protein oxidation and aging. Science, v. 257, p. 1220-1224, 1992.

STEHLE, J.H., SAADE, A.,RAWASHDEH, O., ACKERMANN, K., JILG, A., SEBESTÉNY, T., MARONDE E. A survey of molecular details in the human pineal gland in the light of phylogeny, structure, function and chronobiological diseases. Journal of Pineal Research, v. 51, p. 17-43, 2011.

STURMEY, R.G., Reis, A., Leese, H.J., McEvoy, T.G. Role of fatty acids in energy provision during oocyte maturation and early embryo development. Reproduction in Domestic Animals, v. 44, p. 50-58, 2009.

SUGDEN, D. Melatonin biosynthesis in the mammalian pineal gland. Experientia, v. 45, p. 922-932, 1989.

SUGINO, N. Roles of reactive oxygen species in the corpus luteum. Animal Science Journal, v. 77, p. 556-565, 2006.

SUGINO, N., TAKIGUCHI, S., KASHIDA, S., TAKAYAMA, H., YAMAGATA, Y., NAKAMURA, Y., KATO, H. Suppression of intracellular superoxide dismutase activity by antisense oligonucleotides causes inhibition of progesterone production by rat luteal cells. Biology of Reproduction, v. 61, p. 1133-1138, 1999.

TAKETANI, T., TAMURA, H., TAKASAKI, A., LEE, L., KIZUKA, F., TAMURA, I., TANIGUCHI, K., MAEKAWA, R., ASADA, H., SHIMAMURA, K., REITER, R.J., SUGINO, N. Protective role of melatonin in progesterone production by human luteal cells. Journal of Pin-eal Research, v. 51, p. 207-213, 2011.

TAMURA, H., NAKAMURA, Y., TERRON, M.P., FLORES, L.J., MANCHESTER, L.C., TAN, D.X., SUGINO, N., REITER, R.J. Melatonin and pregnancy in the human. Reproductive Toxicology, v.25, p. 291-303, 2008a.

TAMURA, H., TAKASAKI, A., MIWA, I., TANIGUCHI, K., MAEKAWA, R., ASADA, H., TAKETANI, T., MATSUOKA, A., YAMAGATA, Y., SHIMAMURA, K., MORIOKA, H., ISHIKAWA, H., REITER, R.J., SUGINO, N. Oxidative stress impairs oocyte quality and melatonin protects oocytes from free radical damage and improves fertilization rate. Journal of Pineal Research, v. 44, p. 280-287, 2008b. 
TAMURA, H., TAKASAKI, A., TAKETANI, T., TANABE, M., KIZUKA, F., LEE, L., TAMURA, I., MAEKAWA, R., AASADA, H.,YAMAGATA, Y., SUGINO, N. The role of melatonin as an antioxidant in the follicle. Journal of Ovarian Research, v. 25, p. 5:5, 2012.

TAMURA, H., TAKASAKI, A., TAKETANI, T., TANABE, M., KIZUKA, F., LEE, L., TAMURA, I., MAEKAWA, R., AASADA, H., YAMAGATA, Y., SUGINO, N. Melatonin as a free radical scavenger in the ovarian follicle. Endocrine Journal, v. 60, p. 1-13, 2013.

TAMURA, H., NAKAMURA, Y., KORKMAZ, A., MANCHESTER, L.C., TAN, D.X., SUGINO, N., REITER, R.J. Melatonin and the ovary: Physiological and pathophysiological implication. Fertility and Sterility, v. 92, p. 328-343, 2009.

TAN, D.X., CHEN, L.D., POEGGELER, B., MANCHESTER, L.C., REITER, R.J. Melatonin: a potent endogenous hydroxyl radical scavenger. Endocrine Journal, v. 1, p. 57-60, 1993.

TAN, D.X., MANCHESTER, L.C., REITER, R.J., QI, W., KIM, S.J., ELSOKKARY, G.H. Ischemia/reperfusion-induced arrhythmias in the isolated rat heart: prevention by melatonin. Journal of Pineal Research, v. 25, p. 184191, 1998.

TAN, D.X., MANCHESTER, L.C., REITER, R.J., PLUMMER, B.F., LIMSON, J., WEINTRAUB, S.T., QI, W. Melatonin directly scavenges hydrogen peroxide: a potentially new metabolic pathway of melatonin biotransformation. Free Radical Biology and Medicine, v. 29, p. 1177-1185, 2000.

TAN, D.X., MANCHESTER, L.C., BURKHARDT, S., SAINZ, R.M., MAYO, J.C., KOHEN, R., SHOHAMI, E., HUO, Y.S., HARDELAND, R., REITER, R.J. N1-acetyl-N2-formyl-5-methoxykynuramine, a biogenic amine and melatonin metabolite, functions as a potent antioxidant. The FASEB Journal, v. 15, p. 2294-2296, 2001.

TAN, D.X., REITER, R.J., MANCHESTER, L.C., YAN, M.T., EL SAWI, M., SAINZ, R.M., MAYO, J.C., KOHEN, R., ALLEGRA, M., HARDELAND, R. Chemical and physical properties and potential mechanisms: melatonin as a broad-spectrum antioxidant and free radical scavenger. Current Topics in Medicinal Chemistry, v. 2, p. 181-197, 2002.

TAN, D.X., MANCHESTER, L.C., SAINZ, R.M., MAYO, J.C., ALVAREZ, F., REITER, R.J. Antioxidant strategies in protection against neurodegenerative disorders. Expert Opinion on Therapeutic Patents, v. 13, p. 1513-1543, 2003.

TAN, D.X., MANCHESTER, L.C., TERRON, M.P., FLORES, L.J., TAMURA, H., REITER, R.J. Melatonin as a naturally occurring co-substrate of quinone reductase-2, the putative MT3 melatonin membrane receptor: hypothesis and significance.Journal of Pineal Research, v. 43, p. 317-320, 2007. 
TAN, D.X, HARDELAND, R., MANCHESTER, L.C., ROSALES-CORRAL, S., COTO-MONTES, A., BOGA, J.A., REITER, R.J. Emergence of naturally occurring melatonin isomers and their proposed nomenclature. Journal of Pineal Research, v. 53, p. 113-121, 2012.

TAN, D.X., MANCHESTER, L.C., LIU, X., ROSALES-CORRAL, S.A., ACUNACASTROVIEJO, D., REITER, R.J. Mitochondria and chloroplasts as the original sites of melatonin synthesis: a hypothesis related to melatonin's primary function and evolution in eukaryotes. Journal of Pineal Research, v. 54, p. 127-138, 2013.

TANAKA, M., MIYAZAKI, T., TANIGAKI, S., KASAI, K., MINEGISHI, K., MIYAKOSHI, K., ISHIMOTO, H., YOSHIMURA, Y. Participation of reactive oxygen species in PGF2alpha-induced apoptosis in rat luteal cells. Journal of Reproduction and Fertility, v. 120, p. 239-245, 2000.

THUWANUT, P., CHATDARONG, K., BERGQVIST, A.S., SÖDERQUIST, L., THIANGTUM, K., TONGTHAINAN, D., AXNÉR, E. The effects of antioxidants on semen traits and in vitro fertilizing ability of sperm from the flat-headed cat (Prionailurusplaniceps).Theriogenology, v. 76, p. 115-125, 2011.

TRIPATHI, A., KHATUN, S., PANDEY, A.N., MISHRA, S.K., CHAUBE, R., SHRIVASTAVA, T.G., CHAUBE, S.K. Intracellular levels of hydrogen peroxide and nitric oxide in oocyte at various stages of meiotic cell cycle and apoptosis. Free Radical Research, v. 43, p. 287-294, 2009.

TSUTSUI, K., UBUKA, T., BENTLEY, G.E., KRIEGSFELD, L.J. Review: regulatory mechanisms of gonadotropin-inhibitory hormone $(\mathrm{GnIH})$ synthesis and release in photoperiodic animals. Frontiers in Neuroscience. v. 16, 7:60, 2013.

UCHIDA, K. 4-Hydroxy-2-nonenal: a product and mediator of oxidative stress. Progress in Lipid Research, v. 42, p. 318-343, 2003.

URATA, Y., HONMA, S., GOTO, S., TODOROKI, S., IIDA, T., CHO, S., HONMA, K., KONDO, T. Melatonin induces gammaglutamylcysteinesynthetase mediated by activator protein-1 in human vascular endothelial cells. Free Radical Biology and Medicine, v. 27, p. 838847, 1999.

VAN VOORHIS, B.J., DUNN, M.S., SNYDER, G.D., WEINER, C.P. Nitric oxide: an autocrine regulator of human granulosa-luteal cell steroidogenesis. Endocrinology, v. 135, p. 1799-806, 1994.

VARGAS, A., BUSTOS-OBREGON, E., HARTLEY, R. Effects of hypoxia on epididymal sperm parameters and protective role of ibuprofen and melatonin. Journal of Biological Research, v. 44, p. 161-167, 2011. 
VEGA, M., CARRASCO, I., CASTILLO, T., TRONCOSO, J.L., VIDELA, L.A., DEVOTO, L. Functional luteolysis in response to hydrogen peroxide in human luteal cells. Journal of Endocrinology, v. 147, p. 177-182, 1995.

VENEGAS, C., GARCíA, J.A., ESCAMES, G., ORTIZ, F., LÓPEZ, A., DOERRIER, C., GARCÍA-CORZO, L., LÓPEZ, L.C., REITER, R.J., ACUÑACASTROVIEJO, D. Extrapineal melatonin: analysis of its subcellular distribution and daily fluctuations. Journal of Pineal Research, v. 52, p. 217227, 2012.

VIJAYALAXMI, REITER, R.J., TAN, D.X., HERMAN, T.S., THOMAS, C.R. JR. Melatonin as a radioprotective agent: a review. International Journal of Radiation Oncology Biology Physics, v. 59, p. 639-653, 2004.

VINCENT, L., COHEN, W., DELAGRANGE, P., BOUTIN, J.A., NOSJEAN, O. Molecular and cellular pharmacological properties of 5methoxycarbonylamino-N-acetyltryptamine (MCA-NAT): a nonspecific MT3 ligand. Journal of Pineal Research, v. 48, p. 222-229, 2010.

VON GALL, C., GARABETTE, M.L., KELL, C.A., FRENZEL, S. Rhythmic gene expression in pituitary cells depends on temporally defined heterologous sensitization by the neurohormone melatonin. Nature NeuroScience, v. 5, p. 234-238, 2002.

VU, H.V., ACOSTA, T.J., YOSHIOKA, S., ABE, H., OKUDA, K. Roles of prostaglandin F2alpha and hydrogen peroxide in the regulation of Copper/Zinc superoxide dismutase in bovine corpus luteum and luteal endothelial cells. Reproductive Biology and Endocrinology, v. 26, 10:87, 2012.

WANG, F., TIAN, X., ZHANG, L., TAN, D., REITER, R.J., LIU, G. Melatonin promotes the in vitro development of pronuclear embryos and increases the efficiency of blastocyst implantation in murine.Journal of Pineal Research 55: 267-274; 2013.

WOO, M.M., TAI, C.J., KANG, S.K., NATHWANI, S.P., PANG, S.F., LEUNG, P.C. Direct action of melatonin in human granulosa-luteal cells. The Journal of Clinical Endocrinology and Metabolism, v. 86, p. 4789-4797, 2001.

YANG, H.W., HWANG, K.J., KWON, H.C., KIM, H.S., CHOI, K.W., OH, K.S. Detection of reactive oxygen species (ROS) and apoptosis in human fragmented embryos. Human Reproduction, v. 13, p. 998-1002, 1998.

YONEI, Y., HATTORI, A., TSUTSUI, K., OKAWA, M., ISHIZUKA, B. Effects of Melatonin: Basics Studies and Clinical Applications. Anti-Aging Medicine, v. 7, p. 85-91, 2010.

ZAMBERLAM, G., PORTELA, V., DE OLIVEIRA, J.F., GONÇALVES, P.B., PRICE, C.A. Regulation of inducible nitric oxide synthase expression in bovine ovarian granulosa cells. Molecular and Cellular Endocrinology, v. 335, p. 189-194, 2011. 
ZHANG, M., OUYANG, H., XIA, G. The signal pathway of gonadotropinsinduced mammalian oocyte meiotic resumption. Molecular Human Reproduction, v. 15, p. 399- 409, 2009.

ZHANG, X., LI, X.H., MA, X., WANG, Z.H., LU, S., GUO, Y.L. Redox-induced apoptosis of human oocytes in resting follicles in vitro. Journal of the Society for Gynecologic Investigation, v. 13, p. 451-458, 2006. 


\section{CAPÍTULO II}

O efeito da melatonina em oócitos

suínos maturados in vitro 


\section{RESUMO}

O objetivo deste estudo foi avaliar o efeito da melatonina sobre a maturação de oócitos suínos cultivados in vitro. No experimento I, os oócitos submetidos à maturação in vitro (MIV) em meio TCM199 contendo melatonina $\left(0,10^{-3} \mathrm{M}, 10^{-}\right.$ ${ }^{6} \mathrm{M}$ e $10^{-9} \mathrm{M}$ ) e mantidos em três tempos de maturação (36, 40 ou $44 \mathrm{~h}$ ), foram avaliados quanto à maturação nuclear (taxa de MII) e distribuição dos grânulos corticais (GC periféricos), como indicativo de maturação citoplasmática. No experimento II, os oócitos submetidos à MIV em meio TCM199 contendo melatonina $\left(0,10^{-6} \mathrm{M}\right.$ e $\left.10^{-9} \mathrm{M}\right)$ e mantidos por $44 \mathrm{~h}$, foram avaliados quanto aos níveis de níveis intracelulares de espécies reativas de oxigênio (ROS). No experimento I, a suplementação da melatonina retardou a maturação nuclear no tempo de $36 \mathrm{~h}$ de MIV, independentemente da concentração utilizada em comparação com o controle $(1,7 \% \times 15 \%, \mathrm{P}<0,05)$; às $40 \mathrm{~h}$, por sua vez, somente o grupo tratado com $10^{-6} \mathrm{M}$ de melatonina (33\%) foi similar ao controle $(25 \%, P>0,05)$, e os demais grupos foram superiores $(40 \%, P<0,05)$; e às $44 \mathrm{~h}$, todos os grupos foram similares (38 a 45\%, P>0,05). Com relação à distribuição dos GC, a suplementação de melatonina não influenciou às 36 horas de MIV (3-8\%, P>0,05). No entanto, no tempo de $40 \mathrm{~h}$ de maturação, $10^{-9} \mathrm{M}$ de melatonina levou a uma maior proporção de oócitos com distribuição periférica em relação ao controle $(28 \% \times 7 \%, \mathrm{P}<0,05)$. Às $44 \mathrm{~h}$, os meios contendo $10^{-3} \mathrm{e}$ $10^{-9} \mathrm{M}$ de melatonina foram superiores ao controle $(28 \% \times 12 \%, \mathrm{P}<0,05)$ em relação à proporção de oócitos com $\mathrm{GC}$ em distribuição periférica. No experimento II, a suplementação da melatonina $\left(10^{-6}\right.$ e $\left.10^{-9} \mathrm{M}\right)$ contribuiu para reduzir os níveis intracelulares de ROS $(P<0,01)$, no entanto, a eficácia da melatonina foi mais expressiva $(P<0,05)$ na concentração mais baixa $(12,83 \pm$ 6,$5 ; 17,76 \pm 7,5$ e $23,47 \pm 12,2$ para $10^{-9} ; 10^{-6}$ e $0 \mathrm{M}$; respectivamente). Deste modo, a suplementação do meio de maturação com melatonina estimula a progressão da meiose, a migração de grânulos corticais e reduz os níveis intracelulares de ROS em oócitos de suínos maturados in vitro, indicando um efeito benéfico para oócitos dessa espécie mantidos em condições de cultivo in vitro.

Palavras-chave: ovário, espécies reativas, antioxidante 


\subsection{INTRODUÇÃO}

Oócitos de mamíferos estão sujeitos a danos devido às ações de espécies reativas de oxigênio (ROS), particularmente, durante a maturação in vitro (SOMFAl et al., 2007; ALI et al., 2003), o que resulta em baixa viabilidade oocitária e, consequentemente, baixas taxas de desenvolvimento embrionário (KHALIL et al., 2013). As ROS podem alterar a maioria das moléculas celulares, causando dano mitocondrial, depleção de ATP e apoptose das células embrionárias (GUERIN et al., 2001).

Na espécie suína, a maturação in vitro (MIV) de oócitos tem apresentado limitações adicionais, àquelas apresentadas em gametas femininos de outras espécies. Os oócitos suínos são altamente vulneráveis aos radicais livres e ao estresse oxidativo devido, ao menos em parte, aos seus níveis mais elevados de lipídios citoplasmáticos (GADJA, 2009). Embora os lipídios sejam componentes estruturais e fonte de energia fundamental para 0 desenvolvimento normal do oócito, níveis elevados de lipídios citoplasmáticos comprometem o sucesso das técnicas de reprodução assistida (STURMEY et al., 2009).

A melatonina é um antioxidante muito eficaz e protege as células contra 0 estresse oxidativo (REITER, 2000; TAN et al., 2002; HARDELAND et al., 2011). Além disso, seus metabólitos são igualmente eficazes ou até superiores à molécula progenitora na neutralização das ROS e das espécies reativas de nitrogênio - RNS (TAN et al., 2002; GALANO et al., 2013). A capacidade da melatonina em neutralizar as ROS e RNS, reduzir as concentrações de peróxidos lipídicos e lesões do DNA a torna uma alternativa para promover melhorias na viabilidade das células germinativas e embrionárias (NAKANO et al., 2012; VARGAS et al., 2011; WANG et al., 2013).

Referente a influência da melatonina na maturação, trabalhos realizados com suínos demonstram que a melatonina melhora as taxas de maturação in vitro de oócitos (CHOl et al., 2008; KANG et al., 2009; SHI et al., 2009), bem como qualidade do oócito (RODRIGUEZ- OSORIO et al., 2007). A suplementação com melatonina aumenta a porcentagem de oócitos que atingem a maturação nuclear, além de promover uma redução substancial das 
ROS no grupo de oócitos tratados (KANG et al., 2009). No entanto, não há estudos utilizando melatonina em meio de maturação definido, sem adição de outros fatores que contém melatonina ou de fatores que estimulam a maturação como hormônios durante a MIV de oócitos suínos.

A progressão meiótica e o padrão de distribuição dos grânulos corticais no oócito são indicadores de desenvolvimento oocitário e maturação citoplasmática, respectivamente (DOMINKO; FIRST, 1997; SIRARD, 2001; CARNEIRO et al., 2002). Assim, considerando que melatonina é uma molécula que pode melhorar a qualidade do oócito, esse estudo teve como objetivo avaliar o efeito da adição de melatonina ao meio de maturação oocitária e os níveis intracelulares de ROS em oócitos suínos maturados in vitro.

\subsection{MATERIAL E MÉTODOS}

\subsubsection{Local do experimento}

O estudo, dividido em dois experimentos sequenciais, foi realizado no Laboratório de Histologia Animal do Departamento de Medicina Veterinária na Faculdade de Zootecnia e Engenharia de Alimentos (FZEA) da Universidade do Estado de São Paulo - USP, Campus de Pirassununga - São Paulo.

\subsubsection{Obtenção e seleção dos complexos cumulus-oócitos}

Foram utilizados oócitos oriundos de ovários suínos coletados postmortem em abatedouros comerciais. Os ovários foram acondicionados em garrafas térmicas, mantidos a temperatura de $30-33^{\circ} \mathrm{C}$ e transportados para $\mathrm{o}$ laboratório. Antes da aspiração, os ovários foram lavados com solução salina a temperatura de $33^{\circ} \mathrm{C}$.

O líquido de folículos de 3 a $8 \mathrm{~mm}$ foi aspirado com seringa descartável com agulha $20 \mathrm{G}$ e depositado em tubos cônicos de $50 \mathrm{ml}$, mantidos em banhomaria a $33^{\circ} \mathrm{C}$. Terminada a aspiração, os tubos foram mantidos em repouso por 15 minutos para a sedimentação. Os complexos cumulus-oócitos (CCOs) coletados foram depositados em meio TCM199 contendo Hepes sódico (10mM), Hepes ácido (10mM), bicarbonato de sódio (250mM), PVA $(0,1 \mu \mathrm{l} / \mathrm{ml})$, 
piruvato de sódio $(2,2 \mu \mathrm{g} / \mathrm{ml})$ e amicacina $(16,67 \mu \mathrm{g} / \mu \mathrm{l})$. Os CCOs foram lavados mais duas vezes no mesmo meio e selecionados àqueles que apresentaram ao menos três camadas de células do cumulus e citoplasma homogêneo (LONERGAN et al., 1994).

\subsubsection{Maturação de oócitos}

Os CCOs selecionados foram lavados uma vez no mesmo meio destinado à maturação. Posteriormente, foram distribuídos aleatoriamente de acordo com os tratamentos em placa de quatro poços (20 a 25 oócitos por poço) em meio de maturação in vitro (MIV) constituído de TCM199 contendo bicarbonato de sódio $(250 \mathrm{mM})$, PVA $(0,1 \mu \mathrm{l} / \mathrm{ml})$, piruvato de sódio $(2,2 \mu \mathrm{g} / \mathrm{ml})$ e amicacina $(16,67 \mu \mathrm{g} / \mu \mathrm{l})$, suplementado $\left(10^{-9}, 10^{-6}\right.$ e $\left.10^{-3} \mathrm{M}\right)$ ou não (controle) com melatonina. No meio controle houve adição de gonadotrofinas $(1 \mu \mathrm{g} / \mathrm{mL}$ de FSH e $5 \mu \mathrm{g} / \mathrm{mL}$ de LH). As placas de maturação foram mantidas em incubadora a $38,5^{\circ} \mathrm{C}$ e $5 \%$ de $\mathrm{CO}_{2}$ em ar e alta umidade por 36,40 ou 44 horas.

\subsubsection{Avaliação da maturação oocitária}

Após a maturação, as células do cumulus foram removidas com hialuronidase $0,2 \%$ em PBS livre de $\mathrm{Ca}^{2+}$ e $\mathrm{Mg}^{2+}$ (30 segundos) e após sucessivas pipetagens os oócitos desnudos foram lavados em PBS e fixados com formaldeído (3\%) por $30 \mathrm{~min}$ à temperatura ambiente. Para a permeabilização, os oócitos foram mantidos por 15 min à $38^{\circ} \mathrm{C}$ em solução de bloqueio (PBS com $1 \mathrm{mg} / \mathrm{mL}$ de albumina sérica bovina, $100 \mathrm{mM}$ de glicina e 0,2\% de azida de sódio) acrescida de Triton X-100 (0,1\%).

Posteriormente, foram incubados em $10 \mathrm{mg} / \mathrm{ml}$ de aglutinina de lecitina de Arachis hypogaea conjugada ao isotiocianato de fluoresceína (FITC-PNA). Em seguida, os oócitos foram lavados três vezes em meio de lavagem, corados com $10 \mu \mathrm{g} / \mathrm{ml}$ de Hoechst 33342 em meio TCM199 por 15 minutos, lavados novamente em PBS, montados entre lâmina e lamínula e visualizados em microscópio de epifluorescência (excitação 330-385 nm e emissão 420-490 nm para o Hoechst e excitação 460-490 nm e emissão 515 nm para o FITC). 
Os oócitos foram classificados quanto à maturação nuclear pelo estádio de progressão meiótica (CHERR et al., 1988; AVELINO, 2004), sendo considerados maturos aqueles que alcançaram o estádio de metáfase II - MII (Figura 6). Quanto à maturação citoplasmática, os oócitos foram classificados em função da distribuição dos grânulos corticais - GC (Figura 7), sendo considerados: i) imaturos, aqueles com GC dispostos em aglomerados ou grumos distribuídos por todo o citoplasma; ii) parcialmente maturos ou em transição, os oócitos com GC migrando para a periferia; e iii) maturos, aqueles oócitos com GC dispostos na periferia de forma homogênea (HOSOE e SHIOYA, 1996).

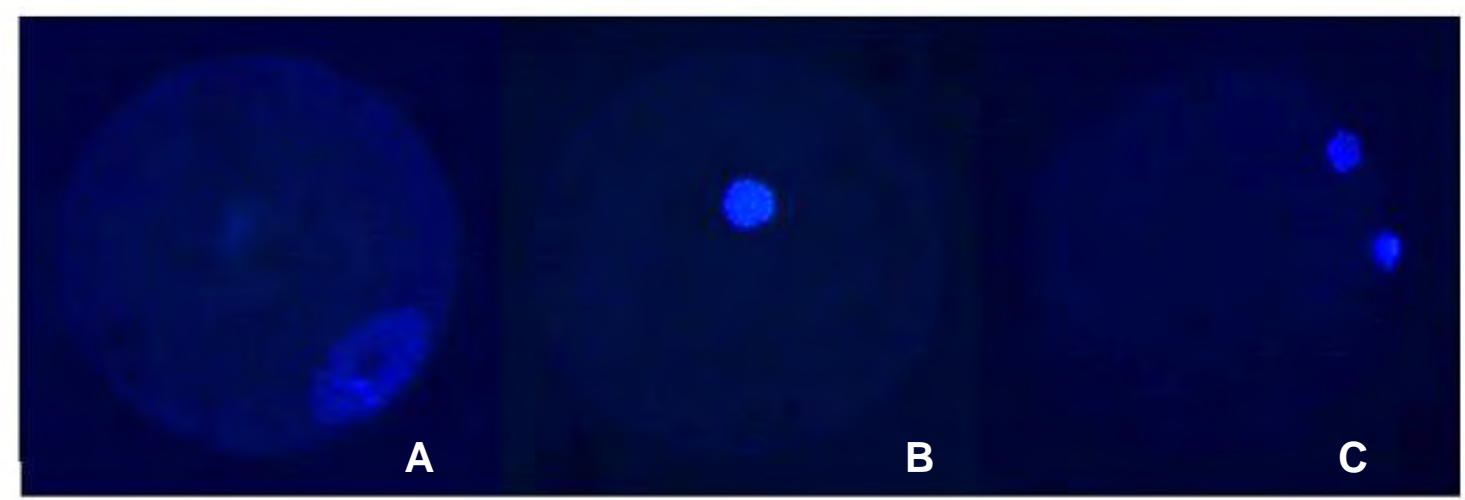

Figura 6. - Aspecto morfológico da progressão nuclear em oócitos suínos maturados in vitro, corados com Hoechst 33342 e avaliados sob microscopia de epifluorescência. (A) Oócito imaturo; (B) Oócito em metáfase I (MI), (C) Oócito maturo em metáfase II (MII) com presença do primeiro corpúsculo polar.

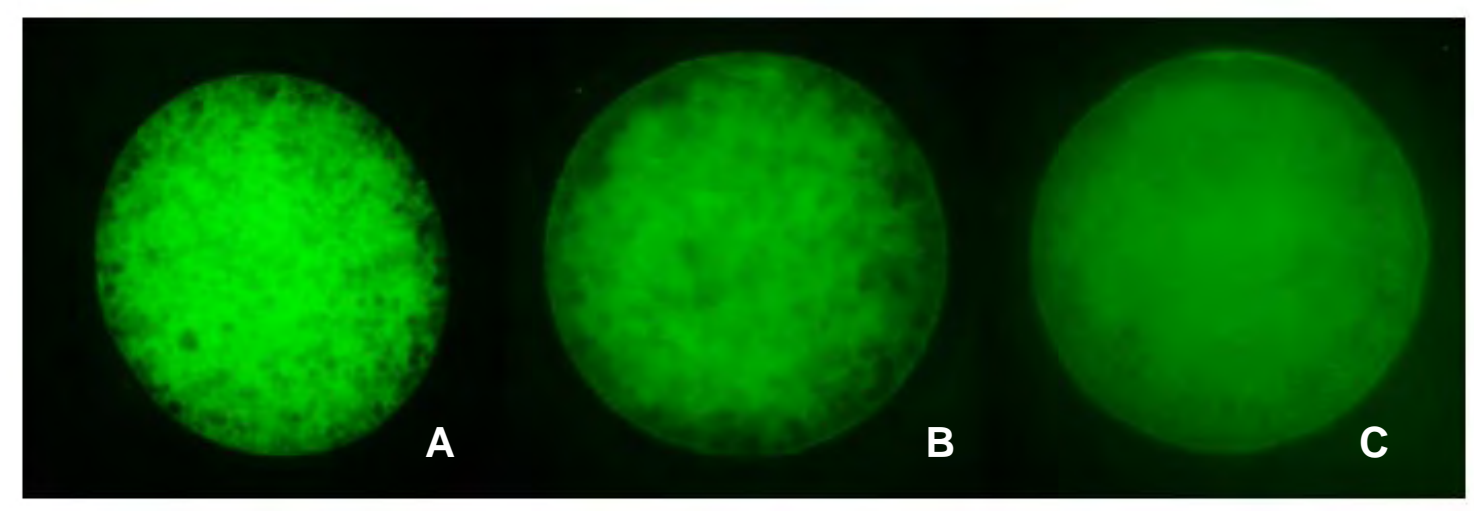

Figura 7. Aspecto morfológico da distribuição dos grânulos corticais (GC) em oócitos suínos maturados in vitro por $44 \mathrm{~h}$, corados com com FITC-PNA, e avaliados sob microscopia de epifluorescência. (a) Oócito imaturo - apresentando GC dispostos em aglomerados no 
citoplasma; (b) Oócito em transição imaturo/maturo - apresentando GC dispostos no citoplasma e na periferia; (c) Oócito maturo - apresentando GC dispostos na periferia.

2.2.5. Determinação dos níveis intracelulares das espécies reativas de oxigênio - ROS

Para detecção dos níveis intracelulares de ROS nos oócitos maturados, as células do cumulus foram removidas e os oócitos permeabilizados como anteriormente descrito. Posteriormente, foram incubados por $10 \mathrm{~min}$ em $10 \mu \mathrm{M}$ do corante intracelular 2,7-diclorofluoresceína-diacetato (DCF-DA, SigmaAldrich). Em seguida, os oócitos foram lavados três vezes em PBS, montados entre lâmina e lamínula e visualizados e fotografados em microscópio de epifluorescência (excitação 460-490 nm e emissão $515 \mathrm{~nm}$ ). As imagens foram então analisadas pelo software Image J (NIH, EUA) em função da intensidade da fluorescência (IF) (Figura 8). Os valores de ROS foram obtidos por meio da equação (Fu et al., 2011):

$$
\text { Intensidade (IF) }=\frac{\text { Eintensidade de fluorescência da área de cada oócito }}{n . \text { amostras }}
$$

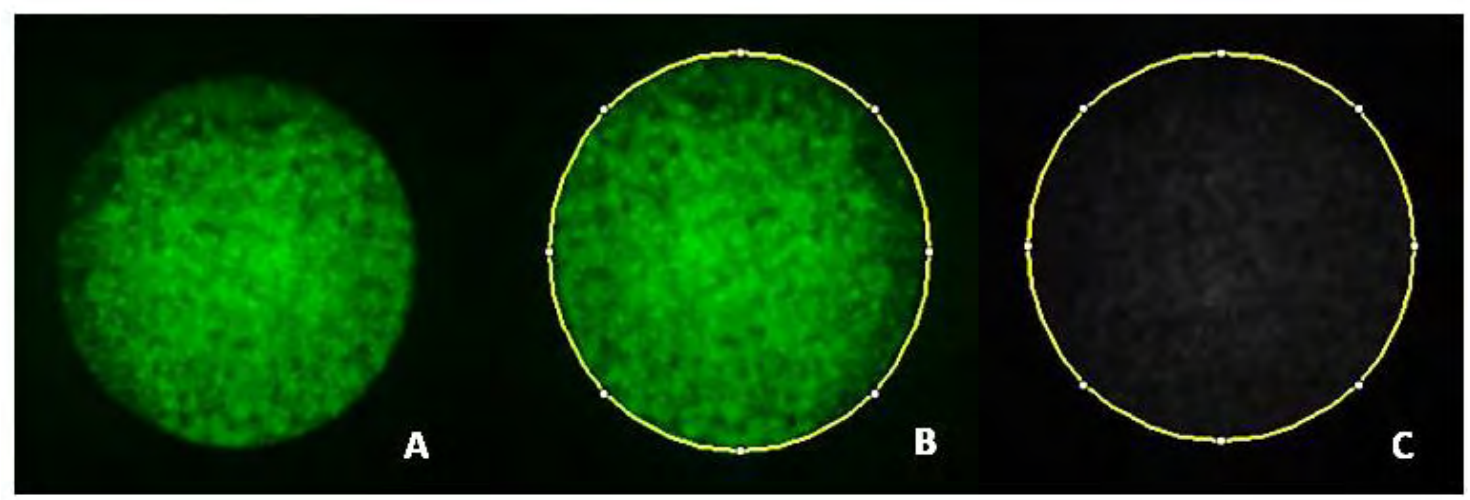

Figura 8. Processamento da imagem origina de oócito suíno maturado por 44 horas para quantificação de radicais livres com DCF-DA (A) mediante o uso do programa ImageJ. Depois de ajustar a escala e passar a imagem para 8 bits (B), a área de fluorescência é determinada (C). 


\subsubsection{Delineamento dos experimentos e análise dos dados}

No experimento I foi avaliado o efeito da melatonina sobre a maturação nuclear e citoplasmática de oócitos suínos maturados in vitro. Os oócitos foram submetidos à maturação em meio TCM199 com ou sem melatonina e, posteriormente, avaliados quanto à progressão meiótica e distribuição dos GC. O delineamento em blocos casualizados foi em esquema fatorial $3 \times 4 \mathrm{com}$ 3 repetições, sendo três tempos de maturação ( 36,40 ou $44 \mathrm{~h}$ ) e quatro concentrações de melatonina (sem melatonina, $10^{-9} \mathrm{M}, 10^{-6} \mathrm{M}$ e $10^{-3} \mathrm{M}$ de melatonina). As taxas de maturação nuclear e citoplasmática obtidas nos quatro meios de maturação (sem melatonina, com $10^{-9} \mathrm{M}$ de melatonina, $10^{-6}$ $\mathrm{M}$ de melatonina e com $10^{-3} \mathrm{M}$ de melatonina), bem como, nos três tempos de maturação (36, 40 ou $44 \mathrm{~h}$ ) foram comparadas pelo teste Qui-quadrado $\left(\chi^{2}\right)$.

No experimento II foi avaliado o efeito da melatonina sobre os níveis intracelulares de ROS em oócitos suínos maturados in vitro. Os oócitos foram submetidos à maturação em meio TCM199 por 44 horas com e sem melatonina; posteriormente, os oócitos foram avaliados quanto aos níveis intracelulares de ROS. O delineamento em blocos casualizados usando 4 tratamentos (sem melatonina, com $10^{-6} \mathrm{M}$ de melatonina, com $10^{-9} \mathrm{M}$ de melatonina e com $1 \mathrm{mM} \mathrm{H}_{2} \mathrm{O}_{2}$, controle positivo / indução do stress oxidativo) com 3 repetições. Os valores de ROS intracelulares foram submetidos à análise de variância (ANOVA) e as diferenças entre as médias obtidas nos três meios de maturação (sem melatonina, com $10^{-6} \mathrm{M}$ de melatonina e com $10^{-9} \mathrm{M}$ de melatonina) foram comparados pelo teste de Tukey, utilizando o programa estatístico Prisma ${ }^{\circledR}$. As diferenças foram consideradas significativas com $\mathrm{P}<0,05$.

\subsection{RESULTADOS}

Após o tratamento com melatonina nas diferentes concentrações, verificamos que após $36 \mathrm{~h}$ de maturação, apenas o grupo $10^{-3} \mathrm{M}(2,0 \%)$ foi inferior ao controle $(15 \%, P<0,05)$, sugerindo que concentrações elevadas de melatonina resultariam em progressão meiótica mais lenta. Às $40 \mathrm{~h}$, por sua vez, somente o grupo tratado com $10^{-6} \mathrm{M}$ de melatonina (33\%) foi similar ao 
controle $(25 \%, P>0,05)$, e os demais grupos foram superiores $(40 \%, P<0,05)$, indicando que a partir desse horário um estímulo à progressão da meiose na concentração mais alta e mais baixa. Às $44 \mathrm{~h}$, todos os grupos foram similares (38 a 45\%, P>0,05), então, embora com pequena variação na cinética, todos os grupos apresentaram índices similares de maturação. A taxa mais baixa foi obtida com a concentração de $10^{-3} \mathrm{M}$ no tempo de $36 \mathrm{~h}(1,7 \%)$ e a taxa mais elevada com a concentração de $10^{-6} \mathrm{M}(45 \%)$ no tempo de $44 \mathrm{~h}$ de maturação (Tabela 1). Conforme esperado, o tempo de maturação interferiu na quantidade de oócitos que atingiram metáfase II. As taxas de maturação nuclear nos tempos de $36 \mathrm{~h}$ foram menores que nos tempos de 40 ou $44 \mathrm{~h}(\mathrm{P}<0,05)$.

Tabela 1. Taxa de maturação nuclear (TMN) de oócitos suínos maturados in vitro por 36, 40 e 44 horas em meio suplementado com $10^{-9}, 10^{-6}$ ou $10^{-3} \mathrm{M}$ de melatonina. $\mathrm{O}$ controle foi maturado sem adição de melatonina

\begin{tabular}{|c|c|c|c|c|c|c|}
\hline \multirow{3}{*}{$\begin{array}{c}\text { Melatonina } \\
\text { (M) }\end{array}$} & \multicolumn{6}{|c|}{ Tempo (h) } \\
\hline & \multicolumn{2}{|c|}{36} & \multicolumn{2}{|r|}{40} & \multicolumn{2}{|c|}{44} \\
\hline & $\mathrm{n}$ & $\%$ & $\mathrm{n}$ & $\%$ & $\mathrm{n}$ & $\%$ \\
\hline 0 (controle) & 60 & $15,0^{\mathrm{Aa}}$ & 60 & $25,0^{A a b}$ & 60 & $41,7^{\mathrm{Ab}}$ \\
\hline $10^{-9}$ & 60 & $6,7^{\mathrm{Aba}}$ & 60 & $40,0^{\mathrm{Bb}}$ & 60 & $43,3^{A b}$ \\
\hline $10^{-6}$ & 60 & $8,3^{\mathrm{Aba}}$ & 60 & $33,3 \mathrm{ABb}$ & 60 & $45,0^{A b}$ \\
\hline $10^{-3}$ & 60 & $1,7^{\mathrm{Ba}}$ & 60 & $40,0^{\mathrm{Bb}}$ & 60 & $38,3^{A b}$ \\
\hline
\end{tabular}

Valores seguidos de letras diferentes, maiúsculas na coluna e minúsculas na linha, diferem pelo teste $\chi^{2}(P<0,05)$.

Em relação ao efeito da melatonina sobre a maturação citoplasmática, às 36 horas não houve influencia da suplementação de melatonina nas taxas de maturação citoplasmática (\% oócitos com maturação citoplasmática indicada por presença dos GC na periferia); sendo todos os grupos similares ao controle (3-8\% aproximandamente, $P>0,05$, Tabela 2). Já nos tempos de 40 e 44 horas houve efeitos positivos da melatonina. Após 40 horas, o grupo tratado com 10${ }^{9} \mathrm{M}$ de melatonina apresentou taxa de maturação citoplasmática superior ao controle (28 e 7\%, aproximadamente, $\mathrm{P}<0,05$ ). As outras concentrações foram intermediárias (12 a 17\%, aproximadamente), sendo similares ao controle e à menor concentração de melatonina $(P>0,05)$. No tempo de 44 horas, a suplementação com melatonina nas concentrações de $10^{-9}$ e $10^{-3} \mathrm{M}$ 
apresentaram taxas de maturação citoplasmática superiores ao grupo controle (28 vs $12 \%$, respectivamente, $P<0,05)$. A concentração intermediária $\left(10^{-6} \mathrm{M}\right)$ teve valores entre o controle e os demais grupos de melatonina (18\%, $\mathrm{P}>0,05)$.

De forma semelhante à maturação nuclear, o tempo de cultivo interferiu na migração de grânulos corticais dos oócitos apenas quando a concentração de melatonina foi $10^{-9}$ e $10^{-3} \mathrm{M}$. No controle e no grupo com $10^{-6} \mathrm{M}$ não houve aumento de migração com o tempo $(P>0,05)$, enquanto que com $10^{-3} \mathrm{M}$ houve aumento progressivo atingindo o máximo com 44 h (3 a 12 a 28\%, $\mathrm{P}<0,05)$. Com $10^{-9} \mathrm{M}$ o pico já foi atingido com $40 \mathrm{~h}(28 \%, \mathrm{P}<0,05)$, mantendo a mesma proporção às $44 \mathrm{~h}(28 \%, \mathrm{P}>0,05)$.

Tabela 2. Taxa de maturação citoplasmática (TMC) de oócitos suínos maturados in vitro por 36,40 e 44 horas em meio suplementado com $10^{-9}, 10^{-6}$ ou $10^{-3} \mathrm{M}$ de melatonina. O controle foi maturado sem adição de melatonina.

\begin{tabular}{|c|c|c|c|c|c|c|}
\hline Melatonina & \multicolumn{6}{|c|}{ Tempo (h) } \\
\hline \multirow[t]{2}{*}{ (M) } & & 36 & & 40 & & 44 \\
\hline & $n$ & TMC (\%) & $n$ & TMC (\%) & $\mathrm{n}$ & TMC (\%) \\
\hline 0 (controle) & 60 & $8,33^{\mathrm{Aa}}$ & 60 & $6,67^{\mathrm{Aa}}$ & 60 & $11,67^{\mathrm{Aa}}$ \\
\hline $10^{-9}$ & 60 & $6,67^{\mathrm{Aa}}$ & 60 & $28,33^{\mathrm{Bb}}$ & 60 & $28,33^{\mathrm{Bb}}$ \\
\hline $10^{-6}$ & 60 & $8,33^{\mathrm{Aa}}$ & 60 & $16,67^{\text {Aba }}$ & 60 & $18,33^{\mathrm{ABa}}$ \\
\hline $10^{-3}$ & 60 & $3,33^{\mathrm{Aa}}$ & 60 & $11,67^{\mathrm{ABb}}$ & 60 & $28,33^{\mathrm{Bc}}$ \\
\hline
\end{tabular}

Valores seguidos de letras diferentes, maiúsculas na coluna e minúsculas na linha, diferem pelo teste $\chi^{2}$ $(P<0,05)$.

Referente aos níveis intracelulares de ROS, a suplementação com melatonina contribuiu para redução dos mesmos $(P<0,01)$, independente da concentração utilizada (Tabela 3). Conforme esperado, os oócitos maturados em meio contendo $\mathrm{H}_{2} \mathrm{O}_{2}$ apresentaram níveis intracelulares de $\mathrm{ROS}$ superiores aos demais grupos $(43,8 \mathrm{IF} ; \mathrm{P}<0,05)$, compatíveis com a indução do estresse oxidativo.

O valor médio dos níveis intracelulares de ROS nos grupos tratados com melatonina (12,8 e 17,8 IF para $10^{-9}$ ou $10^{-6} \mathrm{M}$, respectivamente) foram inferiores aos encontrados em oócitos maturados em meio sem melatonina (23,5 IF; $P<0,05)$. A concentração de melatonina teve influência sobre os níveis 
intracelulares de ROS, sendo que o grupo tratado com a concentração de $10^{-9}$ $M$ apresentou valores inferiores à concentração $10^{-6} M(P<0,05)$.

Tabela 3. Níveis de ROS (média $\pm d p$ )em oócitos suínos maturados in vitro por 44 horas, em meio TCM199 (T0), TCM199 acrescido de diferentes concentrações de melatonina ( $10^{9}$ e 10 $\left.{ }_{6}^{6} \mathrm{M}\right)$, e TCM199 acrescido $1 \mathrm{mM}$ de $\mathrm{H}_{2} \mathrm{O}_{2}$ durante $10 \mathrm{~min}\left(\mathrm{H}_{2} \mathrm{O}_{2}\right)$.

\begin{tabular}{lcc|}
\hline Tratamento & $\begin{array}{c}\text { 44 horas } \\
\text { Níveis de } \mathbf{R O S}^{*}\end{array}$ \\
\hline $\mathbf{H}_{\mathbf{2}} \mathbf{O}_{\mathbf{2}} \mathbf{( 1 \mathbf { ~ m M } )}$ & 75 & $43,8 \pm 14,9^{\mathbf{a}}$ \\
$\mathbf{0}$ (controle) & 75 & $23,5 \pm 12,2_{\mathrm{b}}$ \\
$\mathbf{1 0}^{-9} \mathbf{M}$ & 75 & $12,8 \pm 6,5^{\mathrm{d}}$ \\
$\mathbf{1 0}^{-6} \mathbf{M}$ & 75 & $17,8 \pm 7,5^{\mathrm{c}}$ \\
\hline${ }^{*}$ Intensidade de fluorescência (IF) por $\mu \mathrm{m}^{2}$ & \\
Valores seguidos de letras diferentes, maiúsculas na coluna e minúsculas na linha, diferem pelo teste \\
Tukey $(\mathrm{P}<0,05)$.
\end{tabular}

\subsection{DISCUSSÃO}

No presente estudo foi evidenciada a ação da melatonina na progressão meiótica com pequena variação na cinética da maturação (menor maturação às $36 \mathrm{~h}$ para $10^{-3} \mathrm{M}$ de melatonina e ligeiro aumento às $40 \mathrm{~h}$ para $10^{-9} \mathrm{e} 10^{-3} \mathrm{M}$ de melatonina). Os resultados encontrados no presente estudo, corroboram com os achados prévios, também em suínos, onde relatou-se melhoria na taxa de maturação in vitro (CHOI et al., 2008; KANG et al., 2009; SHI et al., 2009) e na da qualidade do oócito após adição da melatonina ao meio de cultivo, por meio da taxa de clivagem (RODRIGUEZ- OSORIO et al., 2007). De acordo com Galano et al. (2011;2013), esses achados estão, provavelmente, relacionados à capacidade da melatonina e de seus metabólitos em neutralizar os radicais livres.

De forma semelhante, El-Raey et al. (2011), os quais, maturando in vitro oócitos bovinos suplementados com melatonina na concentração de $10^{-9} \mathrm{M}$, detectaram a influência da melatonina sobre a transição nuclear da fase de $\mathrm{Ml}$ para MII, na expansão das células do cumulus e na dispersão das mitocôndrias no citoplasma, proporcionando aumento da taxa de maturação nuclear.

A influência da melatonina na promoção da maturação do oócito já foi documentada nas espécies suína (RODRIGUEZ- OSORIO et al., 2007), 
bubalina (MANJUNATHA et al., 2009), ovina (CASAO et al., 2010) e bovina (EL-RAEY et al., 2011). No entanto, o presente estudo foi o primeiro a utilizar a melatonina em meio de maturação definido, sem adição de outros fatores que contém melatonina como SFB ou FF (KANE, 1985; COELHO et al., 2012; TIAN et al., 2014) ou de fatores que estimulam a maturação como hormônios (FAHIMINIYA; GERARD, 2010). Assim, foi possível evidenciar o efeito exclusivo da adição da indolamina durante a MIV de oócitos suínos.

A importância da utilização da melatonina pura em meio definido se baseia no fato de que utilização de forma associada às gonadotrofinas no meio, poderia alterar o efeito da melatonina e até mesmo mascarar ação da mesma. Assim, nosso estudo mostrou que as concentrações usadas de melatonina foram capazes de estimular a progressão da meiose em proporções similares às obtidos como o uso de gonadotrofinas (controle acrescido de FSH e hCG, sem melatonina).

Em búfalos, Manjunatha et al. (2009) reportaram que a suplementação da melatonina ao meio de maturação melhora significativamente a taxa de maturação nuclear oocitária, provavelmente em consequência da redução do estresse oxidativo, da concentração de peróxido de lipídios e dos danos ao DNA, devido ao efeito protetor e antioxidante da melatonina.

Além disso, estudos anteriores, realizados com peixes, sugerem que a melatonina influencia a ação do fator promotor da maturação (MPF), que age durante a quebra da vesícula germinativa sobre a ruptura do envelope nuclear do oócito (TOKUMOTO et al., 2004; CHATTORAJ et al., 2005). Este poderia ser um mecanismo a explicar como a melatonina poderia estimular a progressão meiótica sem a presença de hormônios.

Estudos tem sugerido que a melatonina influencia o ciclo mitótico e meiótico por meio de genes associados ao ciclo celular (ASKJAER et al., 2002, FUJIMOTO et al., 2011; TORRES et al., 2011), entretanto não havia comprovação. A suplementação com melatonina no meio de maturação estimula genes associados à proliferação celular, formação do fuso mitótico e da carioteca, bem como, movimentação dos centrômeros na formação do fuso mitótico (CRUZ, 2015; dados não publicados Capítulos 4 e 5).

O processo de maturação citoplasmática envolve alterações estruturais e biológicas a fim de preparar o gameta feminino para a fecundação. Durante 
esse processo, há uma redistribuição das organelas citoplasmáticas, dentre elas, os grânulos corticais, as mitocôndrias, o complexo de Golgi e o retículo endoplasmático (DULCIBELLA et al., 1990). Em oócitos das espécies domésticas, a migração dos grânulos corticais é considerada indício de maturação citoplasmática do oócito (DAMIANI et al., 1996; CARNEIRO et al., 2002).

Nossos resultados mostraram que a suplementação com $10^{-9} \mathrm{M}$ de melatonina resulta em melhoria na taxa de maturação citoplasmática após 40 e 44 horas. O efeito da melatonina sobre a maturação citoplasmática, verificada no presente estudo, corrobora com os achados de Kang et al. (2009) e El-Raey et al. (2011). De acordo com Kang et al. (2009), a suplementação do meio de cultivo com melatonina $\left(10^{-9} \mathrm{M}\right)$ durante a MIV aumenta a porcentagem de oócitos que alcançam a maturação citoplasmática. Além disso, El Raey et al. (2011), relataram que a melatonina influencia também na distribuição mitocondrial, ainda que não haja indícios de mudanças no metabolismo das mitocôndrias durante a MIV de oócitos bovinos. É sabido que tanto a atividade metabólica como a reorganização mitocondrial são características fundamentais para a maturação citoplasmática e competência oocitária (HYTTEL et al, 1986, 1997; VAN BLERKOM 2011).

A despeito das taxas de maturação terem sido inferiores àquelas normalmente descritas em estudos anteriores (KANG et al., 2009; SHI et al., 2009), foi observado que além da melatonina proporcionar taxas de maturação nuclear similares àquelas obtidas com o uso de gonadotrofinas, a maturação citoplasmática também foi favorecida pela melatonina nos tempos de 40 e $44 \mathrm{~h}$ de MIV, em especial com a concentração mais baixa $\left(10^{-9} \mathrm{M}\right)$ que foi superior às gonadotrofinas. As taxas de maturação mais baixas em todos os grupos podem ser em consequência de muitas variáveis como, por exemplo, qualidade dos oócitos, idade dos animais, categoria reprodutiva (porcas ou marrãs), época do ano, tempo decorrente entre o abate e a maturação ou mesmo devido ao meio utilizado.

Em relação à influência da melatonina sobre a níveis intracelulares de ROS, a melatonina potencialmente protege o oócito contra o dano oxidativo na medida em que reduziu os níveis intracelulares de ROS no oócito e provavelmente nas células do cumulus. A diminuição substancial de ROS 
intracelular, encontrada no presente estudo, pode ser atribuída à conhecida capacidade antioxidante da melatonina e possivelmente de seus metabólitos mais conhecidos AFMK (N1-acetil-N2-formil-5-metoxiquinuramina) e o AMK (Nacetil-5-metoxiquinuramina) os quais são formadas durante a desintoxicação das espécies reativas pela melatonina (LEON et al., 2004; GALANO et al., 2013).

Além da ação antioxidante direta da melatonina e de seus metabólitos, sabe-se que a melatonina também possui propriedades antioxidantes indiretas, via estímulo a enzimas anti-oxidantes e inibição de pró-oxidantes (REITER et al., 2002; RODRIGUEZ et al., 2004). Assim, considerando que essa ação indireta sobre a diminuição da produção de ROS, provavelmente, ocorre simultânea à ação direta, pode-se sugerir que a suplementação de melatonina ao meio de maturação, na medida em que efetivamente reduz os níveis intracelulares de ROS, proporciona 0 ambiente adequado para 0 desenvolvimento de oócitos suínos durante a MIV.

Dessa forma, a melatonina é capaz de estimular a progressão da meiose e a migração de grânulos corticais em níveis similares ao uso de gonadotrofinas ( $F S H$ e LH) além de proporcionar o ambiente adequado para o cultivo in vitro de oócitos suínos, controlando os níveis intracelulares de ROS durante a maturação.

\section{REFERÊNCIAS}

ALI, A.A., BILODEAU, J.F., SIRARD, M.A. An antioxidant requirement for bovine oocytes varies during in vitromaturation, fertilization and development. Theriogenology, v. 59, p. 939-949, 2003.

ASKJAER P, GALY V, HANNAK E, MATTAJ IW. Ran GTPase cycle and importins alpha and beta are essential for spindle formation and nuclear envelope assembly in living Caenorhabditis elegans embryos. Molecular Biology of the Cell.v. 13, n. 12, p.4355-70, 2002.

AVELINO K.B. 2004. Estimulação e inibição da síntese de glutationa em oócitos bovinos: efeitos sobre a maturação e desenvolvimento embrionário in vitro. Tese de Doutorado em Medicina Veterinária, Reprodução Animal, Universidade Estadual Paulista, Jaboticabal, SP. 92p.

CASAO, A., ABECIA, J.A., CEBRIAN PEREZ, J.A., MUIÑO-BLANCO, T., VÁZQUEZ, M.I., FORCADA, F. The effects of melatonin on in vitro oocyte 
competence and embryo development in sheep. Spanish Journal of Agricultural Research, v. 8, p. 35-41, 2010.

ÇELIK, O., NAZIROĞLU, M. Melatonin modulates apoptosis and TRPM2 channels in transfected cells activated by oxidative stress. Physiology and Behavior, v. 107, p. 458-465, 2012.

CHATTORAJ A, BHATTACHARYYA S, BASU D, BHATTACHARYA $S$, BHATTACHARYA S, MAITRA SK. Melatonin accelerates maturation inducing hormone $(\mathrm{MIH})$ : induced oocyte maturation in carps. General and Comparative Endocrinology. v. 140, p. 145-155, 2005.

CHERR G.N., DROBNIS E.Z. Katz D.F. Localization of cortical granule constituents before and after exocytosis in the hamster egg. Journal of Experimental Zoology, v. 246, p. 81-93, 1988.

CHOI, J., PARK, S.M., LEE, M., KIM, J.H., JEONG, Y.I., LEE, J.Y., PARK, S.W., KIM, H.S., HOSSEIN, M.S., JEONG, Y.W., KIM, S., HYUN, S.H., HWANG, W.S. Anti-apoptotic effect of melatonin on porcine parthenogenic embryos. Molecular Human Reproduction, v. 75, p. 1127-1135, 2008.

EL-RAEY, M., GESHI, M., SOMFAI, T., KANEDA, M., HIRAKO, M., ABDELGHAFFAR, A.E., SOSA, G.A., ABAU EL-ROOS, M.E.A., NAGAI, T. Evidence of melatonin synthesis in the cumulus oocyte complexes and its role in enhancing oocyte maturation in vitro in cattle. Molecular Reproduction and Development, v.78, p. 250-262, 2011.

FUJIMOTO, V.Y., BLOOM, M.S., HUDDLESTON, H.G., SHELLEY, W.B., OCQUE, A.J., BROWNE, R.W. Correlations of follicular fluid oxidative stress biomarkers and enzyme activities with embryo morphology parameters during in vitro fertilization. Fertility and Sterility, v. 96, p. 1357-1361, 2011.

FU, X.W., WU, G.Q., LI, J.J., HOU, Y.P., ZHOU,G.B., WANG,Y.P., ZHU,S.E. Positive effects of Forskolin (stimulator of lipolysis) treatment on cryosurvival of in vitro matured porcine oocytes. Theriogenology. v.75,p. 268-275, 2011.

GADJA, B. Factors and methods of pig oocyte and embryo quality improvement and their application in reproductive biotechnology. Reproductive Biology, v. 9, p. 97-112, 2009.

GALANO, A., TAN, D.X., REITER, R.J. On the free radical scavenging activities of melatonin's metabolites, AFMK and AMK. Journal of Pineal Research, v. 54, p. 245-257, 2013.

GALANO, A., TAN, D.X.,REITER, R.J. Melatonin as anatural ally against oxidative stress: a physicochemical examination. Journal of Pineal Research, v. 51, p. 1-16, 2011.

GILCHRIST RB, RITTER LJ, ARMSTRONG DT. Oocyte-somatic cell interactions during follicle development in mammals. Animal Reproduction Science.v. 82, p. 431-446, 2004. 
GUENTHER, A.L., SCHMIDT, S.I., LAATSCH, H., FOTSO, S., NESS, H., RESSMEYER, A.R. Reactions of the melatonin metabolite AMK (N1-acetyl-5methoxykynuramine) with reactive nitrogen species: formation of novel compounds, acetamidomethyl-6-methoxycinnolinone and 3-nitro-AMK. Journal of Pineal Research, v. 39, p. 251-260, 2005.

GUERIN P, EL MOUATASSIM S, MENEZO Y. Oxidative stress and protection against reactive oxygen species in the pre-implantation embryo and its surroundings. Human Reproduction Update, v. 7, p. 175-189,2001.

HARDELAND, R., CARDINALI, D.P., SRINIVASAN, V., SPENCE, D.W., BROWN, G.M., PANDI-PERUMAL, S.R. Melatonin-a pleiotropic, orchestrating regulator molecule. Progress in Neurobiology, v. 93, p. 350-384, 2011.

HOSOE M, SHIOYA Y. Distribution of cortical granules in bovine oocytes classified by cumulus complex. Zygote, v.5, p.371-376, 1997.

HYTTEL P, FAIR T, CALLENSEN H, GREVE T. Oocyte growth, capacitation and final maturation in cattle. Theriogenology, v.47, p.23-32, 1997.

HYTTEL P, XU KP, SMITH S, GREVE T. Ultrastructure of in vitro oocyte maturation in cattle. Journal of reproduction and fertility, v.78, p.615-625, 1986.

KANE, M. T. A low molecular weight extract of bovine serum albumin stimulates rabbit blastocyst cell division and expansion in vitro. Journal of Reproduction and Fertility, Cambridge, v. 73, p. 147-150, 1985.

KHALIL, W.A.,MAREI, W.F.,KHALID, M.Protective effects of antioxidants on linoleic acid-treated bovine oocytes during maturation and subsequent embryo development. Theriogenology, v.15, p. 161-168, 2013.

LEON, J., ACUÑA-CASTROVIEJO, D., SAINZ, R.M., MAYO, J.C., TAN, D.X., REITER, R.J. Melatonin and mitochondrial function. Life Sciences, v. 75, p. 765-790, 2004.

LONERGAN, P.; MONAGHAN, P.; RIZOS, D.Effect of follicle size on bovine oocyte quality and development competence following maturation, fertilization and culturein vitro.Molecule Reproduction Development, v. 37, p. 48 -53, 1994.

MANJUNATHA, B.M., DEVARAJ, M., GUPTA, P.S.P., RAVINDRA, J.P., NANDI, S. Effect of taurine and melatonin in the culture medium on buffalo in vitro embryo development. Reproduction in Domestic Animals, v. 44, p. $12-$ 16, 2009.

MANNA PR, STOCCO DM. The role of specific mitogen-activated protein kinase signaling cascades in the regulation of steroidogenesis. Journal of Signal Transduction. v. 2011:821615, 2011. 
MEHLMANN LM, JONES TL, JAFFE LA. Meiotic arrest in the mouse follicle maintained by a Gs protein in the oocyte. Science.v. 297(5585), p. 13431345, 2002.

NAKANO, M.,KATO, Y., TSUNODA, Y. Effect of melatonin treatment on the developmental potential of parthenogenetic and somatic cell nucleartransferred porcine oocytes in vitro. Zygote, v. 20, p. 199-207, 2012.

REITER, R.J. Melatonin: Lowering the high price of free radicals. News in Physiological Sciences, v.15, p. 246-250, 2000.

REITER, R.J., TAN, D.X., MANCHESTER, L.C., EL-SAWI, M.R. Melatonin reduces oxidant damage and promotes mitochondrial respiration: implications for aging. Annals of the New YorkAcademy of Sciences, v. 959, p. 238250, 2002.

REITER, R.J., TAN, D.X., MANCHESTER, L.C., PAREDES, S.D., MAYO, J.C., SAINZ, R.M. Melatonin and reproduction revisited. Biology of Reproduction, v.81, p. 445-456, 2009.

RESSMEYER, A.R., MAYO, J.C., ZELOSKO, V., SAINZ, R.M., TAN, D.X., POEGGELER, B., ANTOLIN, I., ZSIZSIK, B.K., REITER, R.J., HARDELAND, R. Antioxidant properties of the melatonin metabolite N1-acetyl-5methoxykynuramine (AMK); scavenging of free radicals and prevention of protein oxidation. Redox Report, v. 8, p. 205-213, 2003.

RODRIGUEZ, C., MAYO, J.C., SAINZ, R.M., ANTOLIN, I., HERRERA, F., MARTIN, V., REITER, R.J. Regulation of antioxidant enzymes: A significant role for melatonin. Journal of Pineal Research, v. 36, p. 1-9, 2004.

RODRIGUEZ-OSORIO, N., KIM, I.J., WANG, H. Melatonin increases cleavage rate of porcine preimplantation embryos in vitro. Journal of Pineal Research, v. 43 , p. $283-288,2007$

SHI, J.M., TIAN, X.Z., ZHOU, G.B., WANG, L., GAO, C., ZHU, S.E., ZENG, S.M., TIAN, J.H.,LIU, G.S. Melatonin exists in porcine follicular fluid and improves in vitro maturation and parthenogenetic development of porcine oocytes. Journal of Pineal Research, v. 47, p. 318-323, 2009.

SOMFAI, T., OZAWA, M., NOGUCHI, J., KANEKO, H., KURIANI KARJA, N.W., FARHUDIN, M., DINNYÉS, A., NAGAI, T., KIKUCHI, K.Developmental competence of in vitro-fertilized porcine oocytes after in vitro maturation and solid surface vitrification: effect of cryopreservation on oocyte antioxidative system and cell cycle. Cryobiology, v. 55, p. 115-126, 2007.

SUTTON-MCDOWALL ML, GILCHRIST RB, THOMPSON JG. The pivotal role of glucose metabolism in determining oocyte developmental competence. Reproduction. v. 139, n. 4, p. 685-95, 2010.

TAKADA L, JUNIOR AM, MINGOTI GZ, BALIEIRO JC, CIPOLLA-NETO J, COELHO LA. Effect of melatonin on DNA damage of bovine cumulus cells 
during in vitro maturation (IVM) and on in vitro embryo development. Research in Veterinary Science, v. 92, n. 1, p. 124-7., 2012.

TAMURA, H., NAKAMURA, Y., KORKMAZ, A., MANCHESTER, L.C., TAN, D.X., SUGINO, N., REITER, R.J. Melatonin and the ovary: Physiological and pathophysiological implication. Fertility and Sterility, v. 92, p. 328-343, 2009.

TAN, D.X., CHEN, L.D., POEGGELER, B., MANCHESTER, L.C., REITER, R.J. Melatonin: a potent endogenous hydroxyl radical scavenger. Endocrine Journal, v. 1, p. 57-60, 1993.

TAN, D.X., MANCHESTER, L.C., BURKHARDT, S., SAINZ, R.M., MAYO, J.C., KOHEN, R., SHOHAMI, E., HUO, Y.S., HARDELAND, R., REITER, R.J. N1-acetyl-N2-formyl-5-methoxykynuramine, a biogenic amine and melatonin metabolite, functions as a potent antioxidant. The FASEB Journal, v. 15, p. 2294-2296, 2001.

TAN, D.X., REITER, R.J., MANCHESTER, L.C., YAN, M.T., EL SAWI, M., SAINZ, R.M., MAYO, J.C., KOHEN, R., ALLEGRA, M., HARDELAND, R. Chemical and physical properties and potential mechanisms: melatonin as a broad-spectrum antioxidant and free radical scavenger. Current Topics in Medicinal Chemistry, v. 2, p. 181-197, 2002.

TOKUMOTO T, TOKUMOTO M, HORIGUCHI R, ISHIKAWA K, NAGAHAMA $Y$. Diethylstilbestrol induces fish oocyte maturation. Proceedings of the National Academy of Sciences. v. 9, n. 101, p. 3686-3690, 2004.

TORRES JZ, SUMMERS MK, PETERSON D, BRAUER MJ, LEE J, SENESE $S$, GHOLKAR AA, LO YC, LEI X, JUNG K, BELMONT L, JACKSON PK. The STARD9/Kif16a kinesin associates with mitotic microtubules and regulates spindle pole assembly. Cell, v. 147, n. 6, p.1309-23, 2011.

VAN BLERKOM J. Mitochondrial function in the human oocyte and embryo and their role in developmental competence. Mitochondrion. v. 11, n. 5, p. 797-813, 2011.

VARGAS, A., BUSTOS-OBREGON, E., HARTLEY, R. Effects of hypoxia on epididymal sperm parameters and protective role of ibuprofen and melatonin. Journal of Biological Research, v. 44, p. 161-167, 2011.

WANG, F., TIAN, X., ZHANG, L., TAN, D., REITER, R.J., LIU, G. Melatonin promotes the in vitro development of pronuclear embryos and increases the efficiency of blastocyst implantation in murine.Journal of Pineal Research 55: 267-274; 2013. 


\section{CAPÍTULO III}

O efeito da melatonina na expressão dos genes antioxidantes envolvidos em funções de proteção celular em meio definido e indefinido 


\section{RESUMO}

Este estudo avaliou o efeito da melatonina na expressão de genes antioxidantes envolvidos na proteção celular de oócitos suínos maturados in vitro. Os oócitos e as células do cumulus foram submetidos à maturação em meio definido (PVA) e indefinido ( $p F F)$ contendo ou não melatonina $\left(10^{-9} \mathrm{M}\right)$ e avaliados quanto à progressão meiótica e expressão dos genes antioxidantes SOD1; SOD2; Catalase e GPX. A suplementação com melatonina não interferiu na taxa de maturação nuclear. A melatonina influenciou positivamente na expressão dos genes SOD1 e Catalase, em oócitos maturados em meio pFF $(P<0,05)$; a melatonina também influenciou na expressão dos genes SOD1 e Catalase, em células do cumulus. A adição da melatonina ao meio PVA não interferiu na a expressão do gene GPX, entretanto aumentou a expressão do SOD2 e Catalase nas células oocitárias e do cumulus. Deste modo, a adição da melatonina ao meio de maturação influencia positivamente na expressão dos genes antioxidantes e, portanto, contribui para a proteção de oócitos suínos e células do cumulus contra o estresse oxidativo.

Palavras-chave: oócito, células do cumulus, expressão gênica

\subsection{INTRODUÇÃO}

Em oócitos e células do cumulus, tal como em outras células, os derivados tóxicos de oxigênio e nitrogênio são importantes mediadores de sinalização intracelular responsáveis por várias funções durante os processos fisiológicos normais (NASR-ESFAHANI; JOHNSON, 1991). As ROS aumentam o potencial de desenvolvimento durante a maturação dos oócitos (MORADO et al., 2009), em especial na retomada da meiose de oócitos pré-ovulatórios mamíferos (TRIPATHI et al., 2009).

Os oócitos, entretanto, são particularmente vulneráveis ao estresse oxidativo (ALI et al., 2003; SOMFAl et al., 2007; KHALIL et al., 2013), devido à composição da membrana plasmática, à presença de altos níveis de lipídios e exposição às mudanças no microambiente, especialmente durante o uso de técnicas artificiais de reprodução (TAMURA et al., 2009). 
A melatonina apresenta propriedades antioxidantes e anti-apoptóticas e atua reduzindo a formação de ROS e espécies reativas de nitrogênio (RNS) (HARDELAND et al., 2011), contribuindo na busca de melhorias nos índices de maturação in vitro oocitária e produção in vitro de embriões.

Os efeitos citoprotetores da melatonina e dos seus derivados estão relacionados com as propriedades antioxidantes diretas (TAN et al., 1993, GALANDO et al., 2013) e indiretas (BARLOW; WALDEN et al., 1995; FISCHER et al., 2013). As atividades diretas da melatonina e os seus metabólitos envolvem a neutralização das ROS e RNS (TAN et al., 1993; CHEN et al., 2013), enquanto que indiretamente, a melatonina estimula enzimas antioxidantes e inibe enzimas pró-oxidativas (REITER et al., 2002; RODRIGUEZ et al., 2004).

O aumento na atividade de SOD (LIU; NG, 2000) parece ser essencial para a manutenção do oócito e das células da granulosa (TAMURA et al., 2012). A melatonina também aumenta a síntese do GSH (URATA et al., 1999), assim como impede a indução da via mitocondrial intrínseca da apoptose através da indução de expressão de Bcl2 e redução da atividade de caspase3, o que contribui para a proteção das células contra o estresse oxidativo e ainda regula a proliferação celular (MOLPECERES et al., 2007). Embora estudos tenham sugerido a habilidade da melatonina em modular a expressão de genes antioxidantes em oócitos e células do cumulus, não há relatos sobre o efeito da melatonina na expressão de genes antioxidantes em oócitos e células do cumulus na espécie suína.

O meio de maturação contendo fluido folicular suíno (pFF) contribui para proteção dos oócitos contra o estresse oxidativo, devido a sua alta concentração de superóxido dismutase, o que favorece a maturação citoplasmática e melhora a competência oocitária (TATEMOTO et al. 2004). Em adição, o pFF contém substâncias que melhoram a expansão das células do cumulus, a progressão meiótica e a fecundação (YOSHIBA et al., 1992). Por outro lado, a utilização do fluido folicular dificulta a padronização da técnica e prejudica a identificação tanto das substâncias essenciais para maturação, quanto dos efeitos das substâncias em análise.

De acordo com Lalantha et al. (1998), a utilização do meio definido (PVA) é capaz de promover maturação nuclear e desenvolvimento embrionário 
subsequente satisfatório, na espécie suína. Na espécie bovina, de forma semelhante, Uto e Yamahama (1996), obtiveram taxas equivalentes de maturação em oócitos bovinos submetidos a meio definido comparado às condições de maturação em meio indefinido. Assim, a utilização de macromoléculas sintéticas, como o álcool polivinílico (PVA), no presente estudo, visou à obtenção de meios de cultura definidos, e dessa forma possibilitou a avaliação da influência do meio sobre o efeito da melatonina.

Desta forma, o objetivo deste estudo foi avaliar o efeito da melatonina e da suplementeção de macromoléculas (meio definido e indefinido) durante a maturação in vitro (MIV) na proteção celular considerando-se a expressão de genes antioxidantes (SOD1, SOD2, Catalase e GPX) em oócitos suínos e suas respectivas células do cumulus.

\subsection{MATERIAL E MÉTODOS}

\subsubsection{Local do experimento}

O estudo, dividido em dois experimentos sequenciais, foi realizado no Laboratório de Reprodução Animal e no Laboratório de Genética da EMBRAPA Suínos e Aves, Unidade de Concórdia - Santa Catarina.

\subsubsection{Obtenção e seleção dos complexos cumulus-oócitos}

Foram utilizados 500 oócitos oriundos de ovários suínos coletados postmortem em abatedouros comerciais. Os ovários foram acondicionados em garrafas térmicas, mantidos à temperatura de $30-33^{\circ} \mathrm{C}$ e transportados para $\mathrm{o}$ laboratório. Antes da aspiração, os ovários foram lavados com solução salina à temperatura de $33^{\circ} \mathrm{C}$.

O líquido de folículos de 3 a $8 \mathrm{~mm}$ foi aspirado com seringa descartável com agulha 20G e depositado em tubos cônicos de $50 \mathrm{ml}$, mantidos em banhomaria a $33^{\circ} \mathrm{C}$. Terminada a aspiração, os tubos foram mantidos em repouso por 15 minutos para a sedimentação. Os complexos cumulus-oócitos (CCOs) coletados foram depositados em meio de lavagem TCM199 contendo Hepes sódico $(10 \mathrm{mM})$, Hepes ácido $(10 \mathrm{mM})$, bicarbonato de sódio $(250 \mathrm{mM})$, PVA 
$(0,1 \mu \mathrm{l} / \mathrm{ml})$, piruvato de sódio $(2,2 \mu \mathrm{g} / \mathrm{ml})$ e amicacina $(16,67 \mu \mathrm{g} / \mu \mathrm{l})$. Os CCOs foram lavados mais duas vezes no mesmo meio e selecionados àqueles que apresentaram ao menos três camadas de células do cumulus e citoplasma homogêneo (LONERGAN et al., 1994).

\subsubsection{Maturação de oócitos}

Os CCOs selecionados foram lavados uma vez em meio de lavagem (Tabela 4). Posteriormente, foram distribuídos aleatoriamente, de acordo com os tratamentos:

- Grupo PVA: os oócitos foram lavados em meio de maturação TCM199 suplementado com 0,1\% de PVA (Tabela 5). Em seguida, grupos de 20 a 25 oócitos foram transferidos para microgotas de $100 \mu \mathrm{L}$ de meio de maturação sob óleo mineral em placa de Petri de $35 \mathrm{~mm}$. Os oócitos foram maturados em estufa úmida a $38,5^{\circ} \mathrm{C}$ em atmosfera contendo baixa tensão de oxigênio ( $5 \%$ de $\mathrm{O}_{2}, 5 \%$ de $\mathrm{CO}_{2}$ e $90 \%$ de $\left.\mathrm{N}_{2}\right)$.

- Grupo PVA + MEL: os oócitos foram lavados em meio de maturação TCM199 suplementado com 0,1\% de PVA (Tabela 5), acrescido com 10${ }^{9} \mathrm{M}$ de melatonina. Em seguida, grupos de 20 a 25 oócitos foram transferidos para microgotas de $100 \mu \mathrm{L}$ de meio de maturação sob óleo mineral em placa de Petri de $35 \mathrm{~mm}$. Os oócitos foram maturados em estufa úmida a $38,5^{\circ} \mathrm{C}$ em atmosfera contendo baixa tensão de oxigênio ( $5 \%$ de $\mathrm{O}_{2}, 5 \%$ de $\mathrm{CO}_{2}$ e $90 \%$ de $\mathrm{N}_{2}$ ).

- Grupo PFF: os oócitos foram lavados em meio de maturação TCM199 suplementado com 10\% de PFF (Tabela 5). Em seguida, grupos de 20 a 25 oócitos foram transferidos para microgotas de $100 \mu \mathrm{L}$ de meio de maturação sob óleo mineral em placa de Petri de $35 \mathrm{~mm}$. Os oócitos foram maturados em estufa úmida a $38,5^{\circ} \mathrm{C}$ em atmosfera contendo baixa tensão de oxigênio ( $5 \%$ de $\mathrm{O}_{2}, 5 \%$ de $\mathrm{CO}_{2}$ e $90 \%$ de $\mathrm{N}_{2}$ ).

- Grupo PFF + MEL: os oócitos foram lavados em meio de maturação TCM199 suplementado com 10\% de PFF (Tabela 5), acrescido com 10${ }^{9} \mathrm{M}$ de melatonina. Em seguida, grupos de 20 a 25 oócitos foram transferidos para microgotas de $100 \mu \mathrm{L}$ de meio de maturação sob óleo mineral em placa de Petri de $35 \mathrm{~mm}$. Os oócitos foram maturados em 
estufa úmida a $38,5^{\circ} \mathrm{C}$ em atmosfera contendo baixa tensão de oxigênio ( $5 \%$ de $\mathrm{O}_{2}, 5 \%$ de $\mathrm{CO}_{2}$ e $90 \%$ de $\mathrm{N}_{2}$ ).

Depois de decorridas 22 horas de maturação, os oócitos foram transferidos para microgotas dos respectivas atmosferas e meios de maturação sem hormônios, com ou sem adição de $10^{-9} \mathrm{M}$ de melatonina, de acordo com o tratamento, nos quais permaneceram por mais 22 horas.

Tabela 4. Componentes e concetração utilizados no meio de lavagem.

\begin{tabular}{|c|c|c|}
\hline Componente & Marca/ n de catálogo & Concentração \\
\hline $\mathrm{NaCl}$ & Sigma s-5886 & $113,7 \mathrm{mM}$ \\
\hline $\mathrm{NaHCO}_{3}$ & Sigma s-5761 & $2 \mathrm{mM}$ \\
\hline Na Lactate & Sigma I-4388 & $12,95 \mathrm{mM}$ \\
\hline Na Pyruvate & Sigma p-4562 & $0,2 \mathrm{mM}$ \\
\hline $\mathrm{NaH}_{2} \mathrm{PO}_{4}$ & Sigma s-5136 & $0,34 \mathrm{mM}$ \\
\hline KCL & Sigma p-5405 & $3,22 \mathrm{mM}$ \\
\hline $\mathrm{CaCl}_{2} 2 \mathrm{H}_{2} \mathrm{O}$ & Sigma c-7902 & $2,04 \mathrm{mM}$ \\
\hline $\mathrm{MgCl}_{2} 6 \mathrm{H}_{2} \mathrm{O}$ & Sigma m-2393 & $0,5 \mathrm{mM}$ \\
\hline Hepes & Sigma h-0891 & $10 \mathrm{mM}$ \\
\hline BSA V & Sigma a-8022 & $3 \mathrm{mM}$ \\
\hline SFB & Nutricell & $10 \%$ \\
\hline Phenol Red & Sigma p-4633 & $0,027 \mathrm{mM}$ \\
\hline
\end{tabular}

Tabela 5. Componentes e concetração utilizados no meio de maturação

\begin{tabular}{|c|c|c|c|}
\hline \multirow{2}{*}{ COMPONENTES } & \multirow{2}{*}{$\begin{array}{l}\text { MARCA/ No DE } \\
\text { CATÁLOGO }\end{array}$} & \multicolumn{2}{|c|}{ CONCENTRAÇÃO } \\
\hline & & TCM 199 + PFF & TCM199 + PVA \\
\hline Piruvato de Sódio & Sigma p-4562 & $0,91 \mathrm{mM}$ & $0,91 \mathrm{mM}$ \\
\hline Cisteina & Sigma c-7352 & $0,57 \mathrm{mM}$ & $0,57 \mathrm{mM}$ \\
\hline Cisteamina & Sigma m-9768 & $50 \mu \mathrm{M}$ & $50 \mu \mathrm{M}$ \\
\hline D-Glicose & Sigma g-6152 & $3,05 \mathrm{mM}$ & $3,05 \mathrm{mM}$ \\
\hline EGF & Sigma e-4127 & $50 U i / m L$ & $50 U i / m L$ \\
\hline HCG & Intervet & $10 U i / m L$ & $10 U i / m L$ \\
\hline ECG & Intervet & $10 U i / m L$ & $10 \mathrm{Ui} / \mathrm{mL}$ \\
\hline Gentamicina & Sigma g-1264 & $50 U i / m L$ & $50 U i / m L$ \\
\hline Álcool polivinílico & Sigma p-8136 & - & $0,10 \%$ \\
\hline Fluído Folicular Suíno & - & $10 \%$ & - \\
\hline
\end{tabular}




\subsubsection{Avaliação da maturação oocitária}

Após a MIV foi realizada a remoção das células do cumulus por meio de sucessivas pipetagens em meio de lavagem a temperatura ambiente. Em seguida, os oócitos desnudos foram lavados três vezes no mesmo meio, corados com $10 \mu \mathrm{g} / \mathrm{ml}$ de Hoechst 33342 em glicerol por 15 minutos, montados entre lâmina e lamínula e visualizados em microscópio de epifluorescência (excitação 330-385nm e emissão 420-490nm). Os oócitos foram classificados quanto à maturação nuclear pelo estádio de progressão meiótica (CHERR et al., 1988; AVELINO, 2004), sendo considerados maturos aqueles que alcançaram o estádio de metáfase II (MII).

\subsubsection{Reação em cadeia de polimerase em tempo real (rt-qPCR)}

Os oócitos e as células do cumulus foram separados por meio de sucessivas pipetagens em meio de lavagem. Os oócitos e as células do cumulus foram lavados três vezes em meio PBS, transferidos para microtubos com $1 \mu \mathrm{L}$ dessa solução e mergulhados no nitrogênio líquido. Todas as amostras foram armazenadas a $-80^{\circ} \mathrm{C}$ até serem submetidas à extração de RNA com o Kit RNA PicoPure ${ }^{\circledR}$, de acordo com as instruções do fabricante.

O RNA extraído foi armazenado à $-80^{\circ} \mathrm{C}$ até o uso. Para a transcrição reversa síntese de RNA complementar foi utilizando o kit SuperScript@ III FirstStrand, seguindo as recomendações do fabricante. A cada amostra de RNA foi adicionado o $1 \mathrm{ul}$ de primer oligoDT (50 uM), 1ul de annealing buffer e 10uL q.s.p. de água ultrapura tratada com DEPC. $\mathrm{O}$ mix foi incubado à $65 \stackrel{\circ}{\circ}$ por 5 minutos e resfriado em gelo por 1 minuto. Foi então adicionado 10 ul de $2 x$ FirstStrand Reaction + 2ul da enzima SuperScript $\Theta$ III/ RNaseOUT Enzime Mix. A amostra retornou ao termociclador à $50 \stackrel{\circ}{\circ} \mathrm{C}$ por 50 minutos, seguindo de aquecimento à $85^{\circ} \mathrm{C}$ por 5 min e posterior resfriamento à $4{ }^{\circ} \mathrm{C}$ para estocagem à $-20^{\circ} \mathrm{C}$.

As amplificações foram realizadas utilizando o QuantStudio ${ }^{\text {TM }} 6$ Flex RealTime PCR System $\AA$. Nas reações para verificar a expressão relativa dos genes alvos e endógenos, foi utilizado para cada gene um mix contendo $10 \mathrm{uL}$ de 
Power SYBR Green® PCR Master Mix 1x (Applied Byosystems), 2 ul de cada par de primer e 7 ul de água ultrapura Milli-Q. Os primers foram sintetizados para os genes das enzimas antioxidantes superóxido dismutases (SOD1 e SOD2), Catalase, glutationa peroxidase (GPX), a partir de seqüências conhecidas do GenBank (Tabela 6). Como controle da reação foram incluídos primers para os genes constitutivos GAPDH, Ubiquitina e Histona H3. A análise da expressão dos genes (SOD1, SOD2, Catalase e GPX) foi feita pelo método $2 \Delta \Delta \mathrm{Ct}$.

Tabela 6. Sequências dos oligonucleotideos iniciadores para os genes das enzimas antioxidantes superóxido dismutases (SOD1 e SOD2), Catalase e glutationa peroxidase $(G P X)$ e bem como para os genes constitutivos GAPDH, Ubiquitina, Histona H3.

\begin{tabular}{cccc}
\hline Gene & & Sequência de Primers & Tamanho $(\mathrm{pb})$ \\
\hline \multirow{2}{*}{ SOD1 } & Sense & CTGTACCAGTGCAGGTCCTC & 106 \\
& AntiSense & TTTGCCAGCAGTCACATTGC & \\
SOD2 & Sense & TGTTGGAAGCCATCAAACGC & 144 \\
& AntiSense & AACAAGCGGCAATCTGCAAG & \\
Cat & Sense & CTGAGTGGCTGAGTCCGAAG & 122 \\
& AntiSense & ATATCAGGTTTCTGCGCGGC & \\
GPX & Sense & CCAGCCATAGGCTCTCCAAG & \multirow{2}{*}{89} \\
& AntiSense & AGGAAAATGAGAGGGCTGC & \\
GAPDH & Sense & TCCTGGGCTACACTGAGGAC & 123 \\
& AntiSense & ACCAGGAAAGAGCTTGACG & \\
Ubiquitina & Sense & ACCAGCAGCGTCTGATTTT & 92 \\
& AntiSense & CAAGTGCAGGGTGGACTCT & \\
& Sense & GTAAGCACCGAGGAAGCAACT & \\
HistonaH3 & AntiSense & GGCCTGTAACGATGAGGTTTCT & 91 \\
& AntiSense & CCTTATCGAGGCCATCTGAA & \\
\hline
\end{tabular}

3.2.7. Delineamento e análise dos dados

Nos Experimentos I e II foram avaliados o efeito da melatonina e de diferentes suplementações de macromoléculas sobre a maturação nuclear de oócitos suínos maturados in vitro e o efeito da melatonina sobre a expressão dos genes antioxidantes (oócitos e células do cumulus), respectivamente. Os oócitos foram submetidos à maturação em meio de maturação definido 
$\left(0,1 \mu \mathrm{l} / \mathrm{ml}\right.$ PVA) e indefinido $\left(0,1 \mu \mathrm{l} / \mathrm{ml}\right.$ fluido folicular suíno) contendo ou não $10^{-}$ ${ }^{9} \mathrm{M}$ de melatonina e avaliados quanto à progressão meiótica (Experimento I) e expressão dos genes antioxidantes Catalase, SOD1, SOD2 e GPX (Experimento II). $O$ delineamento foi interiamente casualisado com quatro tratamentos (pFF, pFF + MEL, PVA e PVA +MEL) em 5 repetições.

Para as comparações entre taxas de maturação nuclear foi utilizado o teste de Qui-quadrado $\left(\chi^{2}\right)$. Para as diferenças na expressão gênica os dados foram submetidos à análise de variância (ANOVA), e comparados pelo teste de Tukey utilizando o programa estatístico Prisma ${ }^{\circledR}$. As diferenças foram consideradas significativas com $\mathrm{P}<0,05$.

\subsection{RESULTADOS}

A suplementação do meio de maturação com melatonina independente do meio de cultivo (definido ou indefinido) não influenciou a taxa de maturação nuclerar que variou de 88 a 97\% (Figura 9, P>0,05). Não houve efeito de meio de cultivo, nem da presença da melatonina, assim como, não houve interação meio-melatonina $(P>0,05)$.
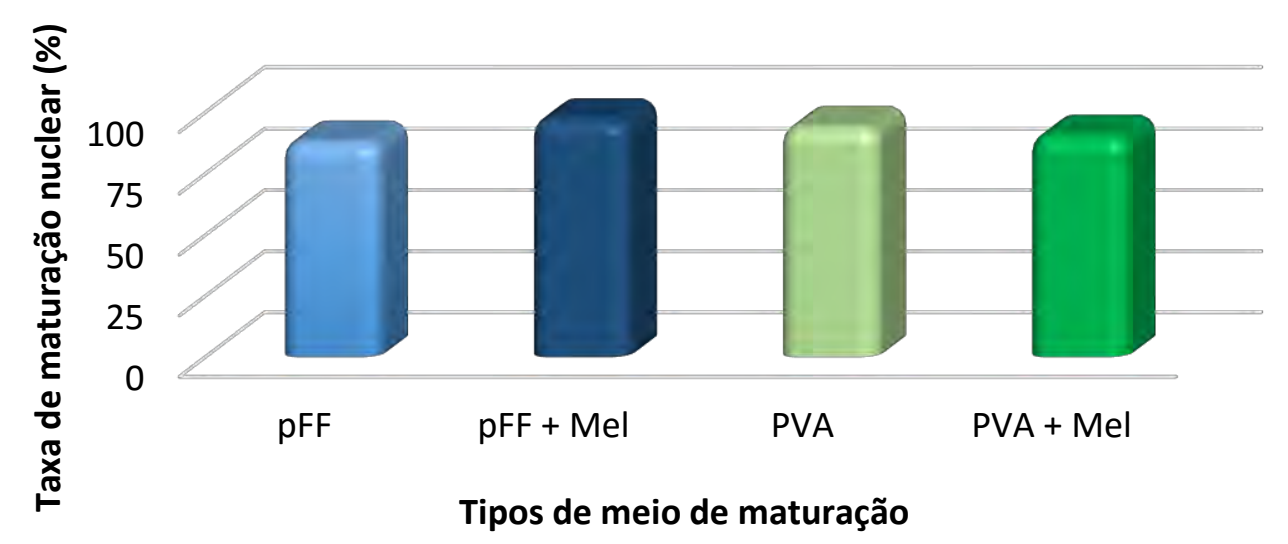

Figura 9. Taxa de maturação de oócitos suínos maturados in vitro, em meio TCM199 suplementado com pFF (fluido folicular) ou PVA com ou sem a adição de $10^{-9} \mathrm{M}$ de melatonina (Mel). 
A melatonina influenciou $(\mathrm{P}<0,05)$ a expressão dos genes Catalase e SOD1 nos oócitos maturados in vitro (Figura 10). Entretanto, a influência sobre a expressão do gene Catalase variou em função do meio de maturação utilizado; quando os oócitos foram maturados em meio indefinido (pFF) a adição de melatonina aumentou a expressão da Catalase e da SOD1, mas quando os oócitos foram maturados em meio defindo (PVA) a melatonina reduziu a expressão da Catalase. $O$ tipo de meio de cultivo também mostrou efeito sobre SOD2 e GPX, sendo que no meio definido (PVA) resultou em redução de transcritos para SOD2 e GPX e incremento da SOD1 $(\mathrm{P}<0,05)$.

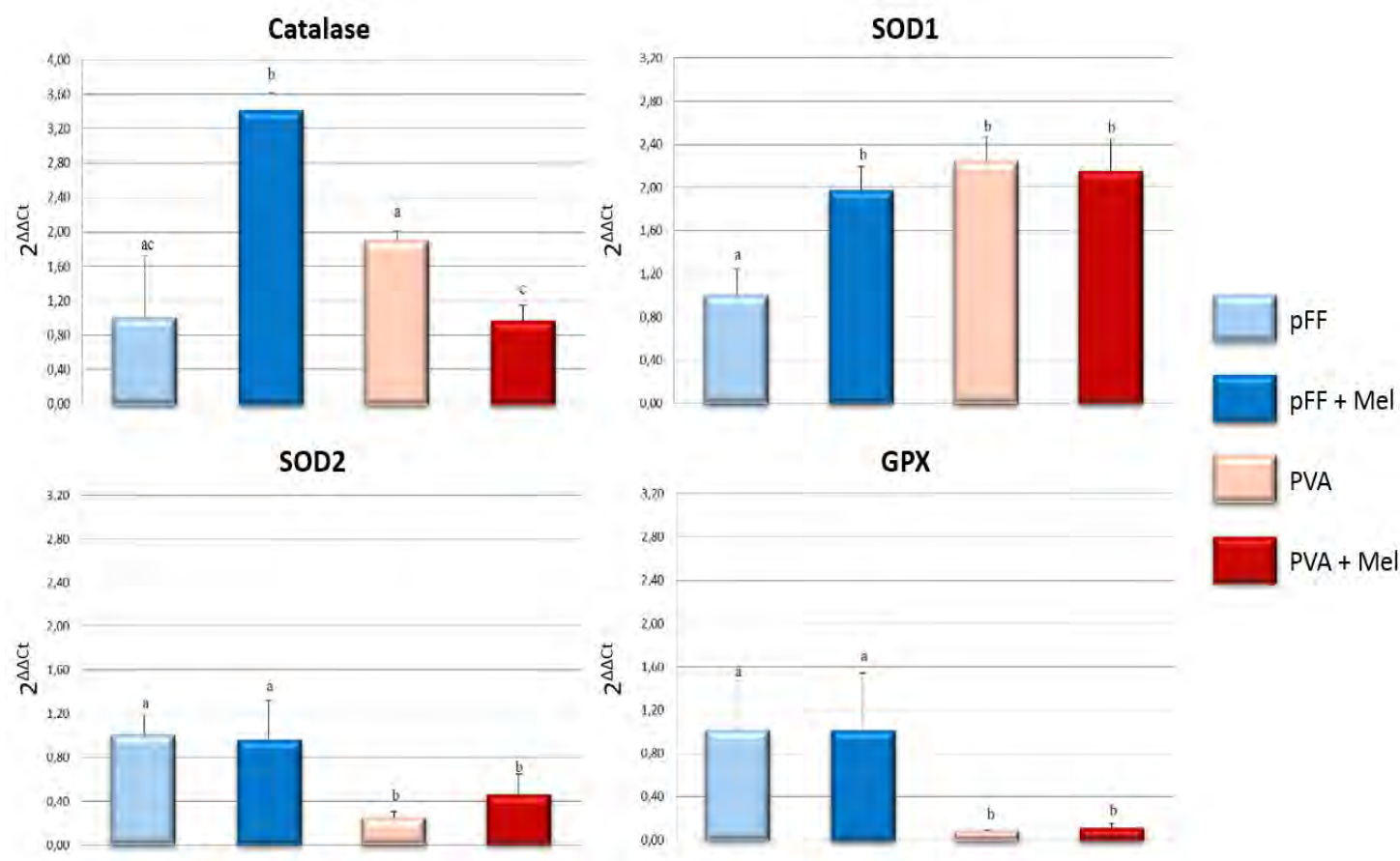

Figura 10. Expressão dos genes Catalase, $S O D 1, S O D 2$ e GPXem oócitos suínos maturados in vitro por $44 \mathrm{~h}$ em meios de maturação definido (PVA) e indefinido (pFF) contendo ou não $10^{-9} \mathrm{M}$ de melatonina. (Os valores foram comparados aos endógenos Histona H3, GAPDH e Ubiquitina)

A melatonina também influenciou a expressão dos quatro genes antioxidantes (Catalase, SOD1, SOD2 e GPX) em células do cumulus, ainda que de forma um pouco diferente, dependendo do meio utilizado (Figura 11). Em células cultivadas em meio de maturação indefinido $(\mathrm{pFF})$, a presença da melatonina elevou a expressão apenas de $S O D 1(\mathrm{P}<0,05)$. No entanto, a suplementação do meio de maturação com melatonina em meio definido (PVA) 
aumentou a expressão da Catalase, SOD2 e GPX $(\mathrm{P}<0,05)$. Em relação ao tipo de meio, o PVA reduziu a expressão de três dos quatro genes avaliados (Catalase, SOD2 e GPX); entretanto a inclusão de melatonina reverteu essa redução, provocando elevação desse mesmos transcritos. Esses resultados sugerem que a melatonina exerce efeitos mais evidentes nas células do cumulus que nos oócitos e são mais influenciados pelo tipo de meio (PVA).

Catalase

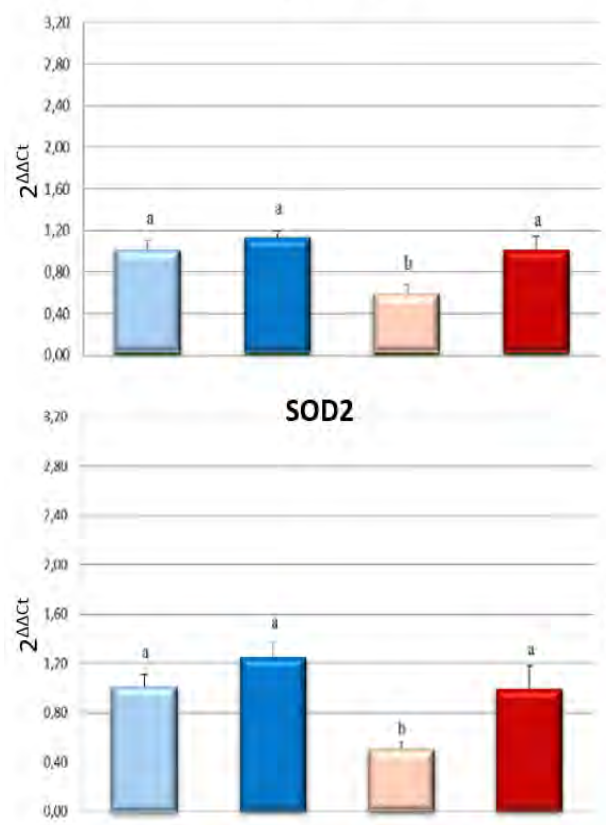

SOD1

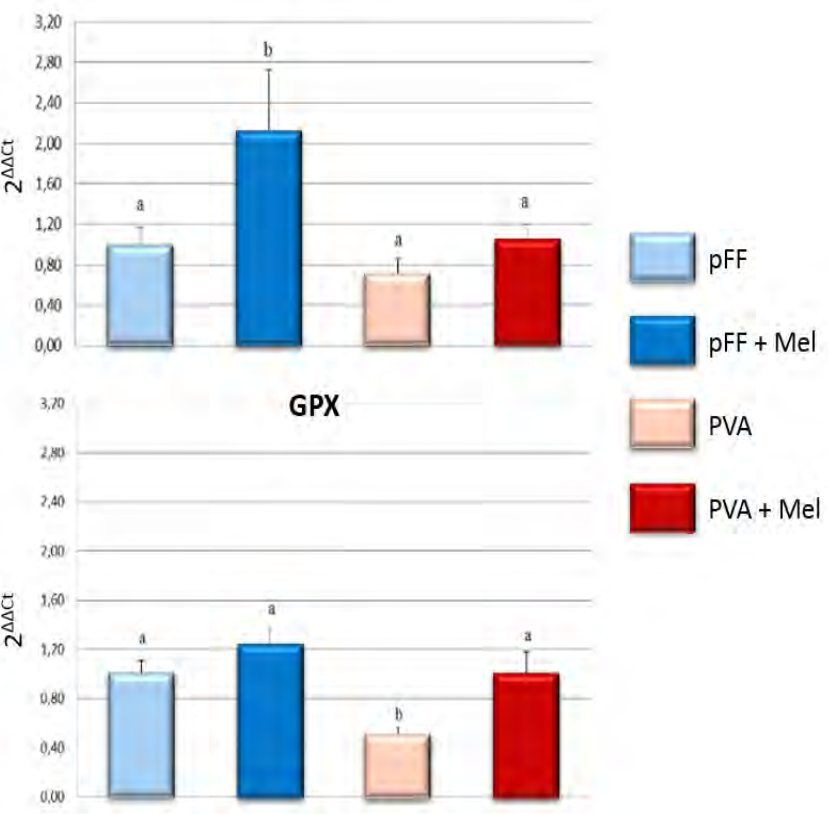

Figura 11. Expressão dos genes Catalase, $S O D 1$, $S O D 2$ e GPX em células do cumulus oriundas de oócitos suínos maturados in vitro por 44h em meios de maturação definido (PVA) e indefinido ( $\mathrm{pFF}$ ) contendo ou não $10^{-9} \mathrm{M}$ de melatonina. (Os valores foram comparados ao endógeno Histona $\mathrm{H} 3$ )

\subsection{DISCUSSÃO}

A progressão meiótica, também chamada de maturação nuclear, é um indicador de desenvolvimento da competência oocitária (DOMINKO; FIRST, 1997). No presente estudo, a melatonina não foi capaz de influenciar a taxa de maturação nuclear, o que provavelmente foi consequência dos índices de maturação ótimos encontrados (acima de $88 \%$ ), podendo assim mascarar o efeito positivo dessa indolamina, bem como da interação da melatonina com o tipo de meio (definido/indefinido). De acordo com Kang et al. (2009), a adição de melatonina ao meio de maturação aumenta a porcentagem de oócitos que 
atingem a maturação nuclear ( 85 vs $75 \%$ ), além de promover uma redução substancial das ROS no grupo de oócitos tratados.

Em relação ao efeito da melatonina sobre a expressão gênica, observouse aumento na expressão gênica de $S O D 1$ em oócitos e células do cumulus no meio pFF assim como aumentando a expressão gência do SOD2 em células do cumulus do meio contendo PVA. Assim, pode-se admitir que o efeito da melatonina sobre a expressão dos genes SOD1 e SOD2 é influenciada pelas macromoléculas presentes no meio de maturação utilizado e/ou pelo tipo celular.

A interação entre a suplementação com melatonina e o tipo de meio (definido/indefinido), pode ser devido ao fato de células cultivadas em meio definido apresentarem nível de proteína total e utilização de substratos energéticos reduzidos (THOMPSON, 1999), uma vez que a síntese de proteínas é fundamental para o desenvolvimento da competência oocitária (SIRARD et al., 1998). Entretanto, o mecanismo pelo qual a melatonina influencia a expressão de genes ainda premanece pouco claro.

Os resultados obtidos no presente estudo corroboram com os achados de Mayo et al. (2002), que mostram o efeito positivo da melatonina $\left(10^{-9} \mathrm{M}\right)$ sobre a expressão de genes antioxidantes SOD1, SOD2 e GPX, em cultura de linhas celulares humanas. $O$ efeito mais evidente da melatonina sobre as células do cumulus que sobre o oócito, devido à interação meio de cultivo-melatonina foi provavelmente consequência da função protetora dessas células. As células do cumulus protegem o oócito contra as espécies reativas e mudanças no microambiente (TATEMOTO et al., 2000) fazendo com que as mesmas se tornem particularmente sensíveis e, portanto, mais responsivas às pequenas variações no meio de cultivo.

O efeito positivo da melatonina sobre as enzimas SOD1 e SOD2, foram demonstrados previamente por Liu e $\mathrm{Ng}$ (2000) e Antolin et al. (1996); a administração exógena de melatonina, via intravenosa, aumentou os níveis de RNAm para as enzimas SOD1 (ratos) e SOD2 (hamster). De acordo com Tamura et al. (2012) e Reiter et al. (2013), o aumento na atividade das SOD reduz significativamente o dano oxidativo intrafolicular e mutilação oxidativa de moléculas essenciais para os folículos ovarianos e viabilidade oocitária. Tal efeito foi resultado da indução de síntese de novas proteinas, visto que a ação 
da melatonina foi inibida quando adicionado um inibidor de síntese proteica (ciclohexamida). Dessa forma admite-se que o efeito da melatonina depende das condições de cultivo.

A adição da melatonina mimetiza sua ação em condições fisiológicas, uma vez que a melatonina regula a expressão gênica das enzimas antioxidantes envolvidas no metabolismo de derivados nocivos de oxigênio e na síntese de outros antioxidantes (TAMURA et al., 2012). Além disso, o aumento da atividade das isoformas de SOD pela melatonina provavelmente impede a indução da via mitocondrial intrínseca da apoptose, por meio da regulação a atividade do gene Bcl2 e da caspase-3 (REITER et al., 2010).

A respeito da expressão de $G P X$, foi possível identificar diferença na sua expressão quando foi utilizado meios diferentes (definido/indefinido), embora a suplementação de melatonina tenha reduzido a expressão de GPX, quando utilizado o meio definido. Esses resultados podem ser consequência da alta variabilidade de amostras, fato comum quando se trabalha com ovários oriundos de matadouro. De acordo com Urata et al. (1999) e Winiarska et al. (2006), a melatonina tem a capacidade de preservar os níveis intracelulares de GSH, mesmo em células sob estresse oxidativo, ao mesmo tempo em que estimula a expressão de GPX. Esses achados são corroborados por BarlowWalden et al., (1995), os quais relatam que a administração exógena de melatonina eleva a atividade da GPX em neurônios de murinos.

Muito embora trabalhos anteriores tenham mostrado que a atividade da Catalase, assim como outras enzimas antioxidantes, pode ser reduzida durante o estresse oxidativo (GOMEZ et al, 2005; TOMAS-ZAPICO; COTO-MONTES, 2005), este é o primeiro estudo que avaliou a ação da melatonina sobre a expressão da Catalase, demonstrando que essa condição pode ser atenuada pela sua adição ao meio. Conforme havia sido sugerido por Reiter et al. (2001) e Rodriguez et al. (2004), a adição de melatonina exógena ao meio de maturação contento pFF resultou em aumento da expressão da Catalase.

Da mesma forma, este estudo demonstrou pela primeira vez a interação entre o tipo de meio (definido/indefinido) e a melatonina na espécie suína evidenciando que a a ação indireta da melatonina sobre a expressão de genes antioxidantes é mais complexa que os estudos anteriores sugeriram (CARPENTIERI et al., 2012 BARLOW; WALDEN et al., 1995; FISCHER et al., 
2013), os quais relatam que as condições de cultivo podem interferir nos resultados encontrados.

Conclui-se que a adição da melatonina ao meio de maturação influencia na expressão dos genes antioxidantes prevenindo contra o estresse oxidativo do oócitos e das células do cumulus suínos maturados in vitro. Em adição, os resultados encontrados apontam para a necessidade de estudos que avaliem o efeito da melatonina sobre a expressão gênica como um todo, uma vez que o efeito da melatonina é influenciado pela presença de macromoléculas no meio de maturação.

\section{REFERENCIAS}

ALI, A.A., BILODEAU, J.F., SIRARD, M.A. An antioxidant requirement for bovine oocytes varies during in vitromaturation, fertilization and development. Theriogenology, v. 59, p. 939-949, 2003.

ANTOLIN, I., RODRIGUEZ, C., SAINZ, R.M., MAYO, J.C., URIA, H., KOTLER, M.L., RODRIGUEZ-COLUNGA, M.J., TOLIVIA, D., MENENDEZ-PELAEZ, A. Neurohormone melatonin prevents cell damage: effect on gene expression for antioxidant enzymes. The FASEB Journal, v. 10, p. 882-890, 1996.

BARLOW-WALDEN, L.R., REITER, R.J., ABE, M., PABLOS, M., MENENDEZ-PELAEZ, A., CHEN, L.D., POEGGELER, B. Melatonin stimulates brain glutathione peroxidase activity. Neurochemistry International, v. 26, p. 497-502, 1995.

BOUEIZ, A., HASSOUN, P.M. Regulation of endothelial barrier function by reactive oxygen and nitrogen species. Microvascular Research, v. 77, p. 2634, 2009.

CADENAS, E., DAVIES, K.J. Mitochondrial free radical generation, oxidative stress, and aging. Free Radical Biology and Medicine, v. 29, p. 222-230, 2000.

DOMINKO T.; FIRST N. L. Timing of meiotic progression in bovine oocytes and its effect on early embryo development. Molecular Reproduction Develelopment, v. 47, p. 456-467, 1997.

FISCHER, T.W., KLESZCZYŃSKI, K., HARDKOP, L.H., KRUSE, N., ZILLIKENS, D. Melatonin enhances antioxidative enzyme gene expression (CAT, GPX, SOD), prevents their UVR-induced depletion, and protects against the formation of DNA damage (8-hydroxy-2'-deoxyguanosine) in ex vivo human skin. Journal of Pineal Research, v. 54, p. 303-312, 2013. 
GALANO, A., TAN, D.X., REITER, R.J. On the free radical scavenging activities of melatonin's metabolites, AFMK and AMK. Journal of Pineal Research, v. 54, p. 245-257, 2013.

HARDELAND, R., CARDINALI, D.P., SRINIVASAN, V., SPENCE, D.W., BROWN, G.M., PANDI-PERUMAL, S.R. Melatonin-a pleiotropic, orchestrating regulator molecule. Progress in Neurobiology, v. 93, p. 350-384, 2011.

KHALIL, W.A.,MAREI, W.F.,KHALID, M.Protective effects of antioxidants on linoleic acid-treated bovine oocytes during maturation and subsequent embryo development. Theriogenology, v.15, p. 161-168, 2013.

LIU, F. AND NG, T.B. Effect of Pineal Indoles on Activities of the Antioxidant Defense Enzymes Superoxide Dismutase, Catalase, and Glutathione Reductase, and Levels of Reduced and Oxidized Glutathione in Rat Tissues. Biochemistry and Cell Biology, 78, 447-453, 2000.

LONERGAN, P.; MONAGHAN, P.; RIZOS, D.Effect of follicle size on bovine oocyte quality and development competence following maturation, fertilization and culturein vitro.Molecule Reproduction Development, v. 37, p. 48 -53, 1994.

MATA-CAMPUZANO, M., ALVAREZ-RODRÍGUEZ, M., DEL OLMO, E., FERNÁNDEZ-SANTOS, M.R., GARDE, J.J., MARTÍNEZ-PASTOR, F. Quality, oxidative markers and DNA damage (DNA) fragmentation of red deer thawed spermatozoa after incubation at $37{ }^{\circ} \mathrm{C}$ in presence of several antioxidants. Theriogenology, v. 78, p. 1005-1019, 2012.

MAYO JC, SAINZ RM, ANTOLI I, HERRERA F, MARTIN V, RODRIGUEZ C. Melatonin regulation of antioxidant enzyme gene expression. Cellular and Molecular Life Sciences v. 59, p. 1706-1173, 2002.

MORADO, S.A., CETICA, P.D., BECONI, M.T., DALVIT, G.C. Reactive oxygen species in bovine oocyte maturation in vitro. Reproduction Fertility and Development, v. 21, p. 608-614, 2009.

NASR-ESFAHANI, M.M., JOHNSON, M.H. The origin of reactive oxygen species in mouse embryos cultured in vitro. Development, v. 113, p. 160-551, 1991.

PABLOS MI, REITER RJ, ORTIZ GG, GUERRERO JM, AGAPITO MT, CHUANG JI, SEWERYNEK E. Rhythms of glutathione peroxidase and glutathione reductase in brain of chick and their inhibition by light. Neurochemistry International, v. 32, p. 69-75; 1998.

REITER, R. J. Melatonin: clinical relevance. Best Practice \& Research Clinical Endocrinology and Metabolism, v. 17, n. 20, p. 273-285, 2003.

REITER, R.J., ROSALES-CORRAL, S.A., MANCHESTER, L.C., TAN, D.X. Peripheral reproductive organ health and melatonin: ready for prime time. International Journal of Molecular Sciences, v. 14, p. 7231-7272, 2013. 
REITER, R.J., TAN, D.X., FUENTES-BROTO, L. Melatonin: a multitasking molecule. Progress in Brain Research, v. 181, p. 127-151, 2010.

REITER, R.J., TAN, D.X., MANCHESTER, L.C., EL-SAWI, M.R. Melatonin reduces oxidant damage and promotes mitochondrial respiration: implications for aging. Annals of the New YorkAcademy of Sciences, v. 959, p. 238250, 2002.

RODRIGUEZ, C., MAYO, J.C., SAINZ, R.M., ANTOLIN, I., HERRERA, F., MARTIN, V., REITER, R.J. Regulation of antioxidant enzymes: A significant role for melatonin. Journal of Pineal Research, v. 36, p. 1-9, 2004.

SOMFAI, T., OZAWA, M., NOGUCHI, J., KANEKO, H., KURIANI KARJA, N.W., FARHUDIN, M., DINNYÉS, A., NAGAI, T., KIKUCHI, K.Developmental competence of in vitro-fertilized porcine oocytes after in vitro maturation and solid surface vitrification: effect of cryopreservation on oocyte antioxidative system and cell cycle. Cryobiology, v. 55, p. 115-126, 2007.

TAMURA, H., NAKAMURA, Y., KORKMAZ, A., MANCHESTER, L.C., TAN, D.X., SUGINO, N., REITER, R.J. Melatonin and the ovary: Physiological and pathophysiological implication. Fertility and Sterility, v. 92, p. 328-343, 2009.

TAMURA, H., TAKASAKI, A., TAKETANI, T., TANABE, M., KIZUKA, F., LEE, L., TAMURA, I., MAEKAWA, R., AASADA, H.,YAMAGATA, Y., SUGINO, N. The role of melatonin as an antioxidant in the follicle. Journal of Ovarian Research, v. 25, p. 5:5, 2012.

TAN DX, CHEN LD, POEGGELER B, MANCHESTER LC, REITER RJ. Melatonin: A potent, endogenous hydroxyl radical scavenger. Endocrine Journal; v. 1, p. 57-60, 1993.

TRIPATHI, A., KHATUN, S., PANDEY, A.N., MISHRA, S.K., CHAUBE, R., SHRIVASTAVA, T.G., CHAUBE, S.K. Intracellular levels of hydrogen peroxide and nitric oxide in oocyte at various stages of meiotic cell cycle and apoptosis.

Free Radical Research, v. 43, p. 287-294, 2009. 


\section{CAPÍTULO IV}

Efeito da melatonina na expressão de genes associados a processos biológicos em células do cumulus: a análise de transcrição gênica 


\section{RESUMO}

O efeito da melatonina na expressão de genes relacionados a processos biológicos em células do cumulus suínas foi avaliado por meio do perfil de trascriptomas, via RNA-Seq. Células do cumulus oriundas de 240 complexos cumulus-oócitos (CCOs) suínos maturadas in vitro com ou sem $10^{-9} \mathrm{M}$ de melatonina, foram separadas e armazenadas a $-80^{\circ} \mathrm{C}$ até serem submetidas à extração de RNA. O preparo das bibliotecas foi realizado conforme o protocolo TruSeq RNA, o mapeamento das amostras foi feito contra o genoma de Sus scrofa e posteriormente os arquivos de mapeamento foram analisados. Após obtenção das contagens das reads, nos grupos com ou sem melatonina, os dados foram submetidos à análise de expressão diferencial. A adição da melatonina ao meio de maturação influenciou na expressão de 80 genes (adjusted $P$-value $<0.05$; fold change $>2$ ) associados a nove processos biológicos. Do ciclo celular aumentou a expressão dos genes FHL2, EPHB4, CCNG2, RAB39B, e reduziu MOK, BTG2 e WEE1; da organização do citoesqueleto aumentou RND1, FNBP1L, FRMD4A, TUBB3, KIF13B, MYO1B e reduziu TUBA1B, MAP1A; da proteólise aumentou TRIM9 e reduziu ANKRD9; da via energética aumentou GNPTAB, PFKFB3, KLHL24, ENO2 e reduziu AGRP, UGDH, PFKFB4; das vias de sinalização aumentou BTBD11, RASSF8, CCDC88C, SDC3, SMAD7, IL10RA, TLR3, PEAK1, TBX2, ABCA1 e reduziu PENK, WNT5A; dos fatores de transcrição aumentou SOX4, AFF2, RCOR2, TRIM24 e ELK3; da adesão e transporte celular aumentou FBLIM1, ZNF606, NCAM1, DSP, TES, e SLC38A1 e diminuiu AQP9, SIDT2; do metabolismo oxidativo e apoptose aumentou KLF4, RSPO2, SLC6A15, PDK4, e diminuiu VAT1L, FMO1, CYB5A e do componente celular aumentou TMEM86A, LAMB1, JUP e DSG2. Conclui-se que a melatonina adicionada ao meio de maturação influencia positivamente na viabilidade de células do cumulus suínas maturadas in vitro, uma vez que modula favoravelmente a expressão de muitos genes diretamente envolvidos nos processos biológicos essenciais para 0 funcionamento celular.

Palavras-chave: ovário, expressão gênica, sequenciamento de RNA. 


\subsection{INTRODUÇÃO}

As células do cumulus (CC) controlam o desenvolvimento e a maturação oocitária por meio de sinais moleculares específicos, fornecem nutrientes e conectam os oócitos com 0 ambiente externo por meio de junções comunicantes (ZHU et al., 2007). As CC agem mantendo o oócito sob bloqueio meiótico e posteriormente participam do processo de indução da retomada meiótica e maturação citoplasmática (BARRETT; ALBERTINI, 2010).

Diversos estudos mostraram correlações de expressão gênica das CC com a maturação do oócito, taxa de fertilização (MCKENZIE et al., 2004) e desenvolvimento embrionário (ASSOU et al., 2010; FEUERSTEIN et al., 2007; HAMEL et al., 2008). A importância da interação desses dois tipos celulares foi demonstrada na comparação dos padrões de expressão gênica entre complexos cumulus-oócitos e oócitos desnudos na espécie suína; em que os oócitos sem a presença do cumulus expressaram RNAm diferente daqueles produzidos em presença do cumulus (ZHU et al., 2007).

No processo de comunicação entre as células do CCOs, têm sido sugeridos dois mecanismos: (1) transferência de moléculas pequenas por meio das junções comunicantes (TSAFRIRI et al. 1972) e (2) por meio de fatores parácrinos e receptores (HUSSEIN et al., 2006). Recentemente Macaulay et al. (2014) mostraram que as células do cumulus têm a capacidade de transferir ativamente, por meio de vesículas, moléculas de RNA para o oócito através das junções comunicantes e, deste modo, as células do cumulus continuam a dar suporte ao oócito após este se tornar transcricionalmente quiescente.

No que se refere à maturação oocitária in vitro (MIV), tem sido constante a busca por alternativas que contribuam para melhorar sua eficácia (NIWA; FUNAHASHI, 1999; KRISHER, 2004). Muitos estudos têm mostrado melhoria na regulação do ciclo celular, metabolisto oxidativo e apoptose, bem como da eficiência da MIV, quando a melatonina é acrescida ao meio de maturação (MATIKAINEN et al., 2001, TAMURA et al., 2009; SHI et al., 2009; MANJUNATHA et al., 2009; CASAO et al., 2010; EL-RAEY et al., 2011).

A melatonina tem uma multiplicidade de ações nas células, cujos efeitos citoprotetores (da melatonina e dos seus derivados) estão relacionados com as propriedades antioxidantes diretas (TAN et al., 1993, GALANDO et al., 2013) e 
indiretas (BARLOW; WALDEN et al., 1995; FISCHER et al., 2013). Enquanto as atividades diretas da melatonina e os seus metabólitos envolvem a neutralização das ROS e RNS (TAN et al., 1993), indiretamente, a melatonina estimula enzimas anti-oxidantes e inibe enzimas pró-oxidativas (REITER et al., 2002; RODRIGUEZ et al., 2004) provavelmente por meio de mecanismos epigenéticos (KORKMAZ et al., 2012).

Estudos recentes têm demonstrado que a administração exógena de melatonina é benéfica na aquisição de competência oocitária (Do et al., 2015), na neutralização direta de radicais livres (CHEN et al., 2013) e no aumento da expressão de genes antioxidantes (CARPENTIERI et al., 2012). Para melhor compreensão do mecanismo de ação dessa indolamina, este estudo teve o objetivo de avaliar o efeito da suplementação da melatonina ao meio de maturação por meio da análise do perfil de trascriptomas de células do cumulus oriundas de complexo cumulus-oócito de suínos, em processos biológicos essenciais para o funcionamento celular.

\subsection{MATERIAL E MÉTODOS}

\subsubsection{Local do experimento}

A coleta das amostras e extração do RNA foram realizadas nos Laboratórios de Reprodução Animal e Genética da EMBRAPA Suínos e Aves, Unidade de Concórdia - Santa Catarina e o preparo das bibliotecas e sequenciamento dos transcritos foram realizados no Laboratório de Biotecnologia Animal - LZT da ESALQ/USP, Piracicaba - São Paulo.

\subsubsection{Obtenção e seleção dos complexos cumulus-oócitos}

Foram utilizados complexos cumulus-oócitos (CCOs) oriundos de ovários suínos coletados post-mortem em abatedouros comerciais. Os ovários foram acondicionados em garrafas térmicas, mantidos a temperatura de $30-33^{\circ} \mathrm{C}$ e transportados para o laboratório. Antes da aspiração, os ovários foram lavados com solução salina a temperatura de $33^{\circ} \mathrm{C}$. O líquido de folículos de 3 a $8 \mathrm{~mm}$ foi aspirado com seringa descartável, com agulha $20 \mathrm{G}$ e depositado em tubos 
cônicos de $50 \mathrm{~mL}$ mantidos em banho-maria a 33ํㅡ. Terminada a aspiração, os tubos foram mantidos em repouso por 15 minutos para a sedimentação. Os complexos CCOs foram localizados e depositados em meio de lavagem [TCM199 com Hepes Sódico (10mM), Hepes Ácido (10mM), bicarbonato de sódio (250mM), PVA (0,1 $\mu \mathrm{L} / \mathrm{ml})$, piruvato de sódio $(2,2 \mu \mathrm{g} / \mathrm{ml})$, amicacina $(16,67$ $\mu g / \mu l)]$.

\subsubsection{Maturação in vitro}

Os CCOs selecionados foram lavados uma vez em meio de lavagem (Tabela 4). Posteriormente, foram distribuídos aleatoriamente, de acordo com os tratamentos:

- Grupo PVA: os oócitos foram lavados em meio de maturação TCM199 suplementado com 0,1\% de PVA (Tabela 5). Em seguida, grupos de 20 a 25 oócitos foram transferidos para microgotas de $100 \mu \mathrm{L}$ de meio de maturação sob óleo mineral em placa de Petri de $35 \mathrm{~mm}$. Os oócitos foram maturados em estufa úmida a $38,5^{\circ} \mathrm{C}$ em atmosfera contendo baixa tensão de oxigênio ( $5 \%$ de $\mathrm{O}_{2}, 5 \%$ de $\mathrm{CO}_{2}$ e $90 \%$ de $\mathrm{N}_{2}$ ).

- Grupo PVA + MEL: os oócitos foram lavados em meio de maturação TCM199 suplementado com 0,1\% de PVA (Tabela 5), acrescido com 10${ }_{9}^{9} \mathrm{M}$ de melatonina. Em seguida, grupos de 20 a 25 oócitos foram transferidos para microgotas de $100 \mu \mathrm{L}$ de meio de maturação sob óleo mineral em placa de Petri de $35 \mathrm{~mm}$. Os oócitos foram maturados em estufa úmida a $38,5^{\circ} \mathrm{C}$ em atmosfera contendo baixa tensão de oxigênio ( $5 \%$ de $\mathrm{O}_{2}, 5 \%$ de $\mathrm{CO}_{2}$ e $90 \%$ de $\mathrm{N}_{2}$ ).

Depois de decorridas 22 horas de maturação, os oócitos foram transferidos para microgotas dos respectivas atmosferas e meios de maturação sem hormônios, com ou sem adição de $10^{-9} \mathrm{M}$ de melatonina, de acordo com o tratamento, nos quais permaneceram por mais 22 horas. 


\subsubsection{Extração de RNA e sequenciamento}

Para verificar a ação da melatonina por RNA-seq foram coletadas células do cumulus oriundas de 240 CCOs suínos divididas em dois tratamentos (com e sem melatonina), em três repetições. Os oócitos e as células do cumulus foram separados por meio de sucessivas pipetagens em meio de lavagem. As células do cumulus foram lavadas três vezes em meio de lavagem, transferidas para criotubos e mergulhadas no nitrogênio líquido. Todas as amostras foram armazenadas a $-80^{\circ} \mathrm{C}$ até serem submetidas à extração de RNA com o Kit RNA PicoPure ${ }^{\circledR}$. O RNA extraído foi depois armazenado à $-80^{\circ} \mathrm{C}$ até o momento do transporte em gelo seco para o sequenciamento.

Para a técnica de sequenciamento, o RNA foi quantificado utilizando o fluorímetro Qubit $\AA$ seguido de uma avaliação qualitativa utilizando 0 BioAnalizer® (Fig. 12).

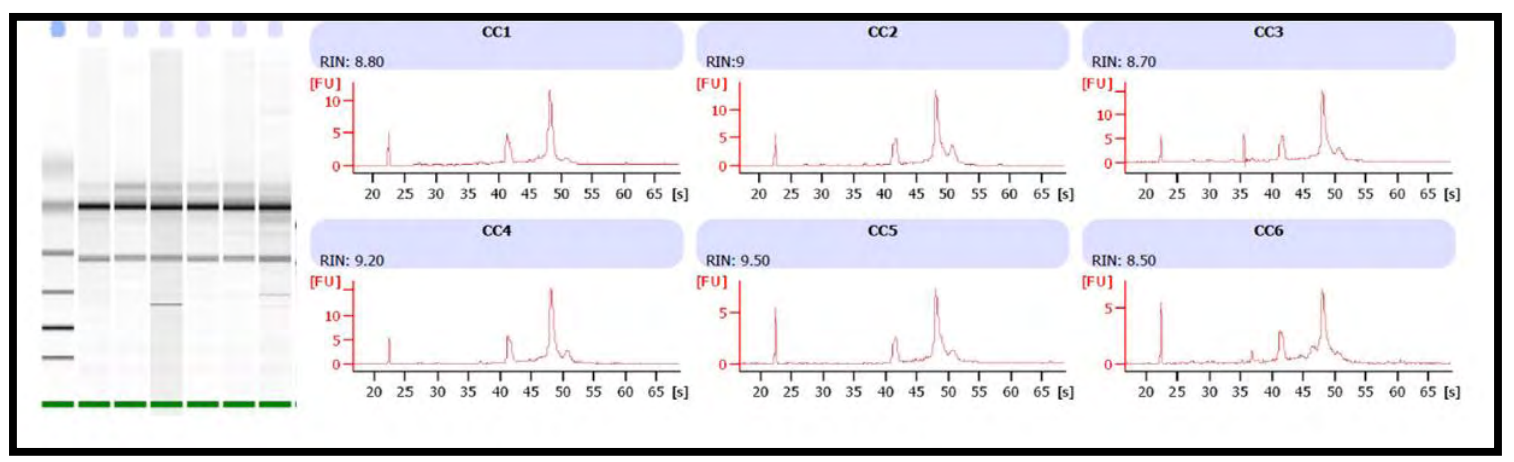

Figura 12. Análise de integridade do RNA utilizando BioAnalizer®

O preparo das bibliotecas foi realizado conforme o protocolo TruSeq RNA

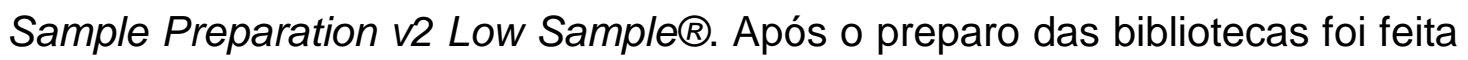
a análise de integridade utilizando o BioAnalizer ${ }^{\circledR}$ (Fig. 13), e tiveram sua diluição ajustada, utilizando PCR em tempo real, e foram colocadas no sequenciador. 


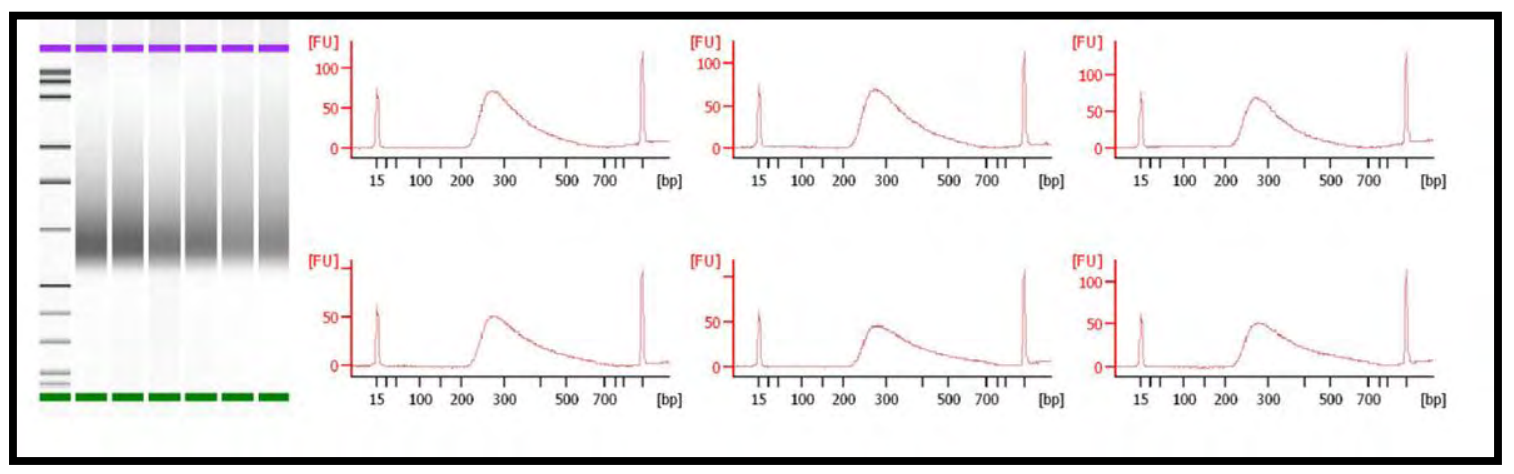

Figura 13. Análise de integridade das bibliotecas utilizando BioAnalizer®

\subsubsection{Análise dos dados}

Pré-processamento e montagem

A etapa de obtenção dos dados brutos obtidos após o sequenciamento foi feita pelo software CASAVA 1.8.2, Illumina, por meio do qual o base call dos dados brutos foi transformado em reads no formato fastq acompanhados dos scores de qualidade phred. Os reads foram visualizados utilizando o programa FastQC v-0.11.3 (www.bioinformatics.bbsrc.ac.uk/ projects/).

A filtragem dos reads de baixa qualidade, sequências de adaptadores e vetores foi realizada pelo programa Seqyclean (https://bitbucket.org/izhbannikov/seqyclean), utilizando como cutoff bases com qualidade inferior a 26QScore. A base de dados de contaminantes usada foi a Univec (http://www.ncbi.nlm.nih.gov/vecscreen/univec.html). Após filtragem, reads com comprimento inferior a $65 \mathrm{pb}$ foram removidos.

\section{Mapeamento}

O mapeamento das amostras foi feito contra o genoma de Sus scrofa (Sscrofa10.2 -Ensembl), utilizando o programa TopHat v-2.1.0 (TRAPNELL et al 2009). A qualidade do mapeamento foi analisada para cada amostra utilizando o pacote Samtools v.1.2 (ferramenta flagstat, LI et al., 2009). Os arquivos de mapeamento foram analisados pelo script do HTSeq-count v.0.6.1 (http://wwwhuber.embl.de/users/anders/htseq/doc/index.html) para extração de contagens brutas dos reads por gene. 
Após obtenção das contagens, os grupos foram analisados usando 0 script dentro do programa DESeq2 (LOVE et al., 2014), um pacote do R/Bioconductor (GENTLEMAN et al., 2004). Por meio do programa DESeq2, os dados foram normalizados pelo tamanho das bibliotecas. Foram utilizados como background os genes que passaram pela filtragem do baseMean $>5$, resultando em 13.298 genes do total de 25.322 genes anotados. Em seguida, as contagens normalizadas dos genes que passaram na filtragem foram analisadas de acordo com um modelo de binomial negativo para obtenção do log2foldchange. Sobre o teste foi aplicada a correção de FDR- BenjaminiHochberg (BENJAMINI; HOCHBERG, 1995) para múltiplos testes a fim de evitar os erros tipo I, ou seja, os falsos positivos.

Para o pacote edgeR - Empirical analysis of digital gene expression data in $R$ (ROBINSON et al., 2010), os dados de cada grupo foram normalizados utilizando TMM (ROBINSON; OSHLACK, 2010) usando a função calcNormFactors. Para evitar artefatos com genes de baixa contagem, após a normalização apenas foram usados os genes com CPM (counts-per-million) > 1 para metade das amostras. A análise de expressão diferencial foi realizada usando a função negativa binomial, assim como foi aplicada a correção de Benjamini-Hochberg (BENJAMINI; HOCHBERG, 1995) para múltiplos testes a fim de evitar falsos positivos. Após a análise de expressão diferencial os genes foram classificados de acordo com sua função, por meio dos sites geneontology.org e david.ncifcrf.gov. O reconhecimento da função do transcrito foi realizado utilizando o respectivo gene ortólogo humano.

\subsection{RESULTADOS}

Do total de 25.322 genes anotados, 13.298 passaram pela filtragem do baseMean $>5$ (background) e 11.282 apresentaram CPM $>1$ para metade das amostras. Na análise de expressão diferencial foram identificados 70 genes (adjusted $P$-value $<0.05$; fold change $>2$ ) que tiveram sua expressão influenciada pela adição da melatonina ao meio de maturação (Figura 14). 
A

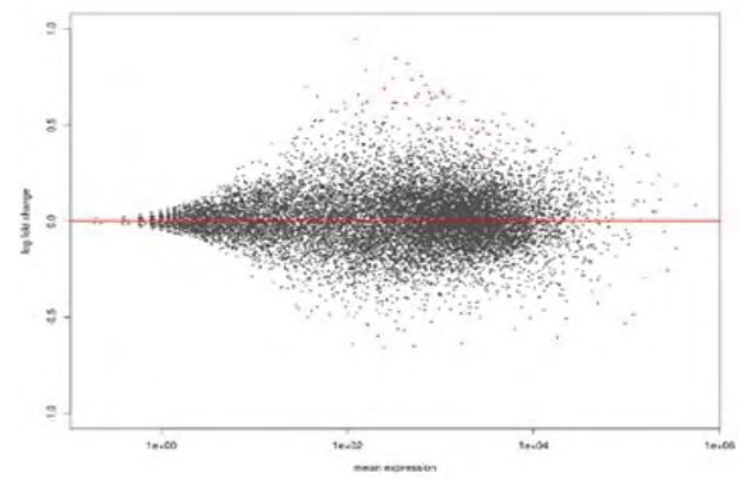

B

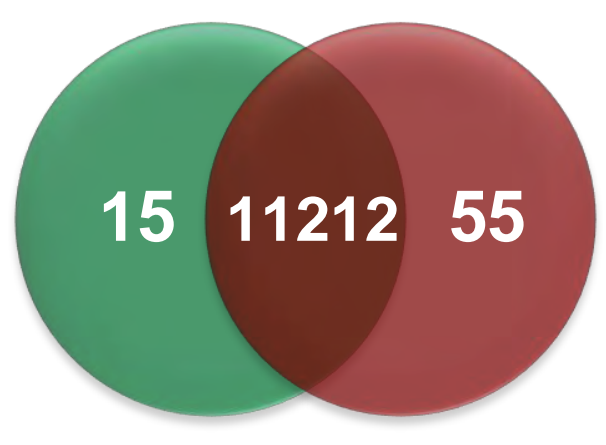

Figura 14. (A) MA plot e (B) Diagrama de Veen do perfil de transcriptomas de células do cumulus oriundas de complexos cumulus-oócitos suínos maturados em meio acrescido com melatonina, análise por RNA-Seq. Em verde o numero de genes com expressão reduzida e em vermelho, com expressão aumentada.

Os 80 genes, cujas expressões foram moduladas pela melatonina $(P<0,05)$ apresentaram níveis de expressão relativamente semelhantes. $O$ fold change encontrado variou entre 3,45 e 5,53, sendo que apenas 13 genes (16,55\% do total de genes diferentemente expressos) apresentaram fold change $>4,5$ (Tabela 7). 
Tabela 7. Níveis de expressão de genes das células do cumulus associados à suplementação de melatonina ao meio de maturação de complexos cumulus-oócitos suínos maturados in vitro. (Continua)

\begin{tabular}{|c|c|c|c|c|c|}
\hline Gene & Símbolo & Nome do gene ${ }^{a}$ & $\begin{array}{l}\text { Fold } \\
\text { change }\end{array}$ & $\begin{array}{c}\text { P- } \\
\text { value }\end{array}$ & Padjb \\
\hline ENSSSCG00000000162 & BTBD11 & $\begin{array}{l}\text { BTB (POZ) domain } \\
\text { containing } 11\end{array}$ & 4,2158 & 0,0001 & 0,0166 \\
\hline ENSSSCG00000000181 & RND1 & Rho family GTPase 1 & 3,8810 & 0,0001 & 0,0413 \\
\hline ENSSSCG00000000295 & MOK & $\begin{array}{l}\text { MOK MAPK/MAK/MRK } \\
\text { overlapping kinase }\end{array}$ & $-3,7554$ & 0,0002 & 0,0510 \\
\hline ENSSSCG00000000559 & RASSF8 & $\begin{array}{lr}\text { Ras } & \text { association } \\
\text { (RalGDS/AF-6) } & \text { domain } \\
\text { family (N-terminal) member } 8\end{array}$ & 3,8890 & 0,0001 & 0,0413 \\
\hline ENSSSCG00000000807 & SLC38A1 & $\begin{array}{l}\text { Sodium-coupled neutral } \\
\text { amino acid transporter } 1\end{array}$ & 3,6261 & 0,0003 & 0,0628 \\
\hline ENSSSCG00000000862 & GNPTAB & $\begin{array}{l}\mathrm{N} \text {-acetylglucosamine-1- } \\
\text { phosphate transferase }\end{array}$ & 4,1058 & 0,0000 & 0,0233 \\
\hline ENSSSCG00000000936 & SLC6A15 & $\begin{array}{l}\text { Solute carrier family } 6 \text {, } \\
\text { member } 15\end{array}$ & 3,6386 & 0,0003 & 0,0628 \\
\hline ENSSSCG00000001025 & DSP & Desmoplakin & 4,3737 & 0,0000 & 0,0098 \\
\hline ENSSSCG00000001081 & SOX4 & $\begin{array}{l}\text { SRY (sex determining region } \\
\text { Y)-box } 4\end{array}$ & 3,8228 & 0,0001 & 0,0450 \\
\hline ENSSSCG00000002440 & CCDC88C & $\begin{array}{l}\text { Coiled-coil domain containing } \\
88 \mathrm{C}\end{array}$ & 3,6295 & 0,0001 & 0,0628 \\
\hline ENSSSCG00000002639 & TUBB3 & Tubulin, beta 3 class III & 4,6466 & 0,0003 & 0,0037 \\
\hline ENSSSCG00000002696 & VAT1L & Vesicle amine transport 1-like & $-3,6536$ & 0,0000 & 0,0615 \\
\hline ENSSSCG00000003465 & FBLIM1 & Filamin binding LIM protein 1 & 5,3984 & 0,0003 & 0,0004 \\
\hline ENSSSCG00000003592 & SDC3 & Syndecan 3 & 3,7475 & 0,0000 & 0,0510 \\
\hline ENSSSCG00000003687 & ANKRD9 & Ankyrin repeat domain 9 & $-3,9395$ & 0,0002 & 0,0375 \\
\hline ENSSSCG00000003995 & ZNF606 & Zinc finger protein 606 & 3,7006 & 0,0001 & 0,0561 \\
\hline ENSSSCG00000004507 & SMAD7 & SMAD family member 7 & 4,9194 & 0,0002 & 0,0014 \\
\hline ENSSSCG00000004597 & AQP9 & Aquaporin 9 & $-3,5655$ & 0,0000 & 0,0691 \\
\hline ENSSSCG00000004705 & MAP1A & Modulador of apoptose & $-3,8340$ & 0,0004 & 0,0450 \\
\hline ENSSSCG00000004875 & CYB5A & Cytochrome b5 & $-3,9206$ & 0,0001 & 0,0387 \\
\hline ENSSSCG00000005025 & TRIM9 & Ttripartite motif containing 9 & 5,1378 & 0,0001 & 0,0009 \\
\hline ENSSSCG00000005437 & KLF4 & Kruppel-like factor 4 & 3,7026 & 0,0000 & 0,0561 \\
\hline ENSSSCG00000006034 & RSPO2 & R-Spondin2 & 3,5968 & 0,0002 & 0,0660 \\
\hline ENSSSCG00000006243 & PENK & Proenkephalin A & $-3,7342$ & 0,0003 & 0,0522 \\
\hline ENSSSCG00000006720 & TUBA1B & Tubulin, alpha $1 \mathrm{~b}$ & $-4,4660$ & 0,0002 & 0,0071 \\
\hline ENSSSCG00000006894 & FNBP1L & Formin binding protein 1 -like & 3,6992 & 0,0000 & 0,0561 \\
\hline ENSSSCG00000007067 & JAG1 & Delta-like protein & 4,6730 & 0,0002 & 0,0036 \\
\hline ENSSSCG00000007675 & EPHB4 & EPH receptor B4 & 4,8589 & 0,0000 & 0,0017 \\
\hline ENSSSCG00000008147 & FHL2 & $\begin{array}{l}\text { Four And A Half LIM Domains } \\
2\end{array}$ & 5,2215 & 0,0000 & 0,0008 \\
\hline ENSSSCG00000008164 & MAP4K4 & $\begin{array}{l}\text { Mitogen-activated protein } \\
\text { kinase kinase kinase kinase } 4\end{array}$ & 3,4802 & 0,0000 & 0,0823 \\
\hline ENSSSCG00000008346 & APLF & $\begin{array}{l}\text { Aprataxin and PNKP like } \\
\text { factor }\end{array}$ & 3,4989 & 0,0005 & 0,0804 \\
\hline ENSSSCG00000008988 & CCNG2 & Cyclin G2 & 4,9428 & 0,0005 & 0,0014 \\
\hline ENSSSCG00000009250 & PRKG2 & $\begin{array}{l}\text { Protein kinase, cGMP- } \\
\text { dependent, type II }\end{array}$ & 3,4244 & 0,0000 & 0,0965 \\
\hline ENSSSCG00000009683 & KIF13B & Kinesin-like protein & 3,5875 & 0,0006 & 0,0663 \\
\hline ENSSSCG00000010651 & AGRP & $\begin{array}{ll}\text { Agouti related protein } \\
\text { homolog }\end{array}$ & $-3,4260$ & 0,0003 & 0,0965 \\
\hline ENSSSCG00000011079 & PIP4K2A & $\begin{array}{l}\text { Phosphatidylinositol-5- } \\
\text { phosphate 4-kinase, type II, } \\
\text { alpha }\end{array}$ & 3,6960 & 0,0006 & 0,0561 \\
\hline ENSSSCG00000011125 & GATA3 & GATA binding protein 3 & 3,9457 & 0,0002 & 0,0375 \\
\hline ENSSSCG00000011133 & PFKFB3 & $\begin{array}{l}\text { 6-phosphofructo-2- } \\
\text { kinase/fructose-2,6- } \\
\text { biphosphatase } 3\end{array}$ & 3,4285 & 0,0001 & 0,0965 \\
\hline ENSSSCG00000011353 & PFKFB4 & $\begin{array}{l}\text { 6-phosphofructo-2- } \\
\text { kinase/fructose-2,6- } \\
\text { biphosphatase } 4\end{array}$ & $-3,4145$ & 0,0006 & 0,0989 \\
\hline ENSSSCG00000011775 & KLHL24 & Kelch-like family member 24 & 3,8040 & 0,0006 & 0,0462 \\
\hline ENSSSCG00000012730 & AFF2 & AF4/FMR2 family & 3,5929 & 0,0001 & 0,0660 \\
\hline ENSSSCG00000013049 & RCOR2 & REST Corepressor 2 & 3,4835 & 0,0003 & 0,0823 \\
\hline ENSSSCG00000013252 & F2 & Prothrombin & 3,4594 & 0,0005 & 0,0879 \\
\hline ENSSSCG00000013360 & TMEM86A & Transmembrane protein $86^{a}$ & 4,2892 & 0,0005 & 0,0133 \\
\hline ENSSSCG00000013411 & WEE1 & WEE1 G2 checkpoint kinase & 3,6866 & 0,0000 & 0,0571 \\
\hline
\end{tabular}


Tabela 7. Níveis de expressão de genes das células do cumulus associados à suplementação de melatonina ao meio de maturação de complexos cumulus-oócitos suínos maturados in vitro. (Conclusão)

\begin{tabular}{|c|c|c|c|c|c|}
\hline Gene & Símbolo & Nome do gene ${ }^{a}$ & $\begin{array}{c}\text { Fold } \\
\text { change }\end{array}$ & $\begin{array}{c}\text { P- } \\
\text { value }\end{array}$ & Padj $^{b}$ \\
\hline ENSSSCG00000013422 & LPPR3 & $\begin{array}{l}\text { Lipid phosphate } \\
\text { phosphatase-related } \\
\text { protein type } 3\end{array}$ & 4,4729 & 0,0002 & 0,0071 \\
\hline ENSSSCG00000015045 & NCAM1 & $\begin{array}{l}\text { Neural cell adhesion } \\
\text { molecule } 1\end{array}$ & 3,7452 & 0,0000 & 0,0510 \\
\hline ENSSSCG00000015074 & SIDT2 & $\begin{array}{l}\text { SID1 transmembrane } \\
\text { family member } 2\end{array}$ & $-3,8777$ & 0,0002 & 0,0413 \\
\hline ENSSSCG00000015085 & IL10RA & Interleukin -L10 receptor & 4,9738 & 0,0001 & 0,0014 \\
\hline ENSSSCG00000015268 & FMO1 & $\begin{array}{l}\text { Dimethylaniline } \\
\text { monooxygenase } 1\end{array}$ & $-3,8102$ & 0,0000 & 0,0462 \\
\hline ENSSSCG00000015334 & PDK4 & $\begin{array}{l}\text { Pyruvate dehydrogenase } \\
\text { kinase, isozyme } 4\end{array}$ & 3,7877 & 0,0001 & 0,0479 \\
\hline ENSSSCG00000015444 & LAMB1 & Laminin, beta 1 & 4,7964 & 0,0002 & 0,0022 \\
\hline ENSSSCG00000015801 & TLR3 & Toll-like receptor 3 & 3,5695 & 0,0000 & 0,0690 \\
\hline ENSSSCG00000015874 & ACVR1 & Activin type I receptor & 3,9160 & 0,0004 & 0,0387 \\
\hline ENSSSCG00000016061 & MYO1B & Myosin 1B & 3,8295 & 0,0001 & 0,0450 \\
\hline ENSSSCG00000016095 & CLK1 & CDC-like kinase 1 & 3,4968 & 0,0001 & 0,0804 \\
\hline ENSSSCG00000016140 & OSGIN2 & $\begin{array}{l}\text { Oxidative stress induced } \\
\text { growth inhibitor family } \\
\text { member } 2\end{array}$ & 3,6471 & 0,0005 & 0,0619 \\
\hline ENSSSCG00000016518 & TRIM24 & $\begin{array}{l}\text { Tripartite motif containing } \\
24\end{array}$ & 4,3691 & 0,0003 & 0,0098 \\
\hline ENSSSCG00000016636 & TES & Testis derived transcript & 3,5527 & 0,0000 & 0,0705 \\
\hline ENSSSCG00000017298 & TANC2 & Protein TANC2 & 3,5056 & 0,0004 & 0,0798 \\
\hline ENSSSCG00000017428 & JUP & Junction plakoglobin & 3,6271 & 0,0005 & 0,0628 \\
\hline ENSSSCG00000017607 & NCKAP1L & $\begin{array}{l}\text { NCK-associated protein } \\
\text { 1-like }\end{array}$ & $-3,8504$ & 0,0003 & 0,0449 \\
\hline ENSSSCG00000020727 & PEAK1 & $\begin{array}{l}\text { Pseudopodium-enriched } \\
\text { atypical kinase } 1\end{array}$ & 5,5267 & 0,0001 & 0,0004 \\
\hline ENSSSCG00000022128 & MXI1 & MAX Interactor 1 & 3,5598 & 0,0000 & 0,0696 \\
\hline ENSSSCG00000022203 & PCSK6 & $\begin{array}{l}\text { Protein convertase } \\
\text { subtilisin/kexin type } 6\end{array}$ & 3,5944 & 0,0004 & 0,0660 \\
\hline ENSSSCG00000022739 & DSG2 & Desmoglein 2 & 3,7778 & 0,0003 & 0,0479 \\
\hline ENSSSCG00000023803 & ELK3 & $\begin{array}{l}\text { ETS domain-containing } \\
\text { protein Elk-3 }\end{array}$ & 5,0350 & 0,0002 & 0,0013 \\
\hline ENSSSCG00000024233 & RAB39B & $\begin{array}{l}\text { Member RAS oncogene } \\
\text { Family }\end{array}$ & 3,5472 & 0,0000 & 0,0710 \\
\hline ENSSSCG00000025134 & FAM171B & $\begin{array}{l}\text { Family with sequence } \\
\text { similarity } 171 \mathrm{~B}\end{array}$ & 3,7810 & 0,0004 & 0,0479 \\
\hline ENSSSCG00000026109 & StAR & $\begin{array}{ll}\text { Steroidogenic } & \text { acute } \\
\text { regulatory protein }\end{array}$ & $-4,1373$ & 0,0002 & 0,0213 \\
\hline ENSSSCG00000026173 & ABCA1 & ATP-binding cassette A1 & 4,5881 & 0,0000 & 0,0046 \\
\hline ENSSSCG00000026362 & HES1 & $\begin{array}{l}\text { Hairy and enhancer of } \\
\text { split-1 }\end{array}$ & 4,0087 & 0,0000 & 0,0314 \\
\hline ENSSSCG00000027060 & TBX2 & T-box 2 (TBX2), mRNA. & 3,6069 & 0,0001 & 0,0655 \\
\hline ENSSSCG00000028322 & BTG2 & BTG family, member 2 & 3,5073 & 0,0003 & 0,0798 \\
\hline ENSSSCG00000028373 & ENO2 & Enolase 2 & 3,5733 & 0,0005 & 0,0690 \\
\hline ENSSSCG00000028447 & FRMD4A & $\begin{array}{l}\text { FERM domain- } \\
\text { containing } 4^{\text {a }}\end{array}$ & 3,6168 & 0,0004 & 0,0640 \\
\hline ENSSSCG00000028506 & CRELD2 & $\begin{array}{l}\text { Cysteine-rich with EGF- } \\
\text { like domains } 2\end{array}$ & $-3,6780$ & 0,0003 & 0,0579 \\
\hline ENSSSCG00000029852 & WNT5A & Protein Wnt & $-4,0555$ & 0,0002 & 0,0277 \\
\hline ENSSSCG00000030150 & UGDH & $\begin{array}{l}\text { UDP-glucose } \\
\text { dehydrogenase }\end{array}$ & $-3,5414$ & 0,0001 & 0,0716 \\
\hline
\end{tabular}

aSímbolo e nome de gene ortólogo humano.

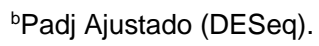


A suplementação do meio de maturação com melatonina variou em função do gene avaliado, aumentando ou diminuindo os níveis de expressão. A melatonina aumentou a expressão de 55 genes (Tabela 7) e reduziu a expressão de 15 genes (Tabela 8).

A análise funcional do perfil de transcriptomas mostrou que a suplementação do meio de maturação com melatonina resulta em aumento na expressão de genes associados a nove processos biológicos: ciclo celular, organização de citoesqueleto, proteólise, via energética, vias de sinalização, fatores de transcrição, adesão e transporte celular, metabolismo oxidativo e apoptose e componente celular (Tabela 7).

Tabela 8. Processos biológicos de transcritos que tiveram a expressão aumentada nas células do cumulus com a suplementação da melatonina ao meio de maturação. ( $n=62$; adjusted Pvalue $<0.05$; fold change $>2$ )

\begin{tabular}{|c|c|c|}
\hline Processo biológico & $\mathrm{N}^{\circ}$ de genes & Genes $^{a}$ \\
\hline Vias de sinalização & 10 & $\begin{array}{l}\text { BTBD11, RASSF8, CCDC88C, } \\
\text { SDC3, SMAD7, IL10RA, TLR3, } \\
\text { PEAK1, TBX2, ABCA1 }\end{array}$ \\
\hline Adesão e transporte celular & 10 & $\begin{array}{l}\text { FBLIM1, ZNF606, NCAM1, DSP, } \\
\text { FNBP1L, TES, DSG2, BTG2, } \\
\text { SLC6A15 e SLC38A1 }\end{array}$ \\
\hline $\begin{array}{c}\text { Metabolismo oxidativo e } \\
\text { apoptose }\end{array}$ & 8 & $\begin{array}{c}\text { KLF4, RSPO2, FHL2, BTG2, } \\
\text { SLC6A15, PDK4. SLC6A15 e } \\
\text { PFKFB3 }\end{array}$ \\
\hline $\begin{array}{l}\text { Organização do } \\
\text { citoesqueleto }\end{array}$ & 7 & $\begin{array}{c}\text { RND1, FNBP1L, TES, FRMD4A, } \\
\text { TUBB3, KIF13B, MYO1B }\end{array}$ \\
\hline Ciclo celular & 6 & $\begin{array}{c}\text { FHL2, EPHB4, CCNG2, RAB39B, } \\
\text { FBLIM1, KIF13B }\end{array}$ \\
\hline Fator de transcrição & 5 & $\begin{array}{c}\text { SOX4, AFF2, RCOR2, TRIM24, } \\
\text { ELK3 }\end{array}$ \\
\hline Via energética & 4 & $\begin{array}{c}\text { GNPTAB, PFKFB3, KLHL24, } \\
\text { ENO2, }\end{array}$ \\
\hline Componente celular & 4 & TMEM86A, LAMB1, JUP, DSG2 \\
\hline Proteólise & 1 & TRIM9 \\
\hline
\end{tabular}

Por outro lado, a suplementação do meio de maturação com melatonina reduziu a expressão de genes associados a oito processos biológicos: ciclo celular, proteólise, via energética, transporte intra/extracelular, vias de sinalização, metabolismo oxidativo e apoptose e componente celular (Tabela 8). A melatonina inibiu principalmente os genes relacionados ao metabolismo oxidativo e apoptose, à via energética e vias de sinalização. 
Tabela 9. Processos biológicos de transcritos que tiveram a expressão reduzida em células do cumulus com a suplementação da melatonina ao meio de maturação. ( $n=18$; adjusted Pvalue $<0.05$; fold change $>2$ )

\begin{tabular}{ccc}
\hline Processo Biológico & $N^{\circ}$ de genes & Genes $^{a}$ \\
\hline $\begin{array}{c}\text { Metabolismo oxidativo e } \\
\text { apoptose }\end{array}$ & 5 & VAT1L, FMO1, WNT5A, AGRP, CYB5A \\
Via energética & 3 & AGRP, UGDH, PFKFB4 \\
Dinâmica de microtúbulos & 2 & TUBA1B, MAP1A \\
Via de sinalização & 2 & PENK, WNT5A \\
Proteólise & 1 & ANKRD9 \\
Transporte & 1 & AQP9, SIDT2 \\
intra/extracelular & 1 & MOK \\
Ciclo celular & &
\end{tabular}

A suplementação do meio de maturação aumentou a expressão dos genes FHL2, EPHB4, CCNG2, RAB39B, FBLIM1e KIF13B e reduziu dos genes MOK, BTG2 e WEE1, cujas funções estão associadas a regulação do ciclo celular e divisão celular. Além disso, a melatonina influenciou genes relacionados com a dinâmica do citoesqueleto (RND1, FNBP1L, TES, FRMD4A, TUBB3, KIF13B e MYO1B). A melatonina poderia regular a degradação de proteínas mediada pela via ubiquitina-proteassoma por meio do aumento e redução da expressão dos genes TRIM9 e ANKRD9, respectivamente.

A melatonina influenciou os genes associados a adesão celular (FBLIM1, ZNF606, NCAM1, DSP, FNBP1L, TES, DSG2 e BTG2), transporte intra/extracelular (SLC6A15, SLC38A1, AQP9 e SIDT2), transcrição celular (SOX4, AFF2, RCOR2, TRIM24 e ELK3) e vias energéticas (PRKG2, PIP4K2A, WEE1, LPPR3, ABCA1, PDK4).

Além disso, a melatonina poderia regular o equilíbrio glicólise/glicogênese por meio da expressão de seis genes relacionados (GNPTAB, PFKFB3, KLHL24, ENO2, PFKFB4 e UGDH). A suplementação do meio de maturação com melatonina aumentou a expressão de genes anti-apoptóticos (KLF4, RSPO2, FHL2 e BTG2) e antioxidantes (SLC6A15, PFKFB3 e PDK4) e reduziu a expressão dos genes oxidantes FMO1, WNT5A, AGRP e CYB5A.

A melatonina estimulou principalmente os genes relacionados à adesão $\mathrm{e}$ ao transporte celular e vias de sinalização (17\%), metabolismo oxidativo e 
apoptose (15\%) e organização do citoesqueleto (12\%) (Figura 15a). Quando comparado o número de genes cuja expressão aumentou versus aqueles que tiveram a expressão reduzida, apenas o metabolismo oxidativo apresentou um número maior de genes menos expressos (Figura 15b).

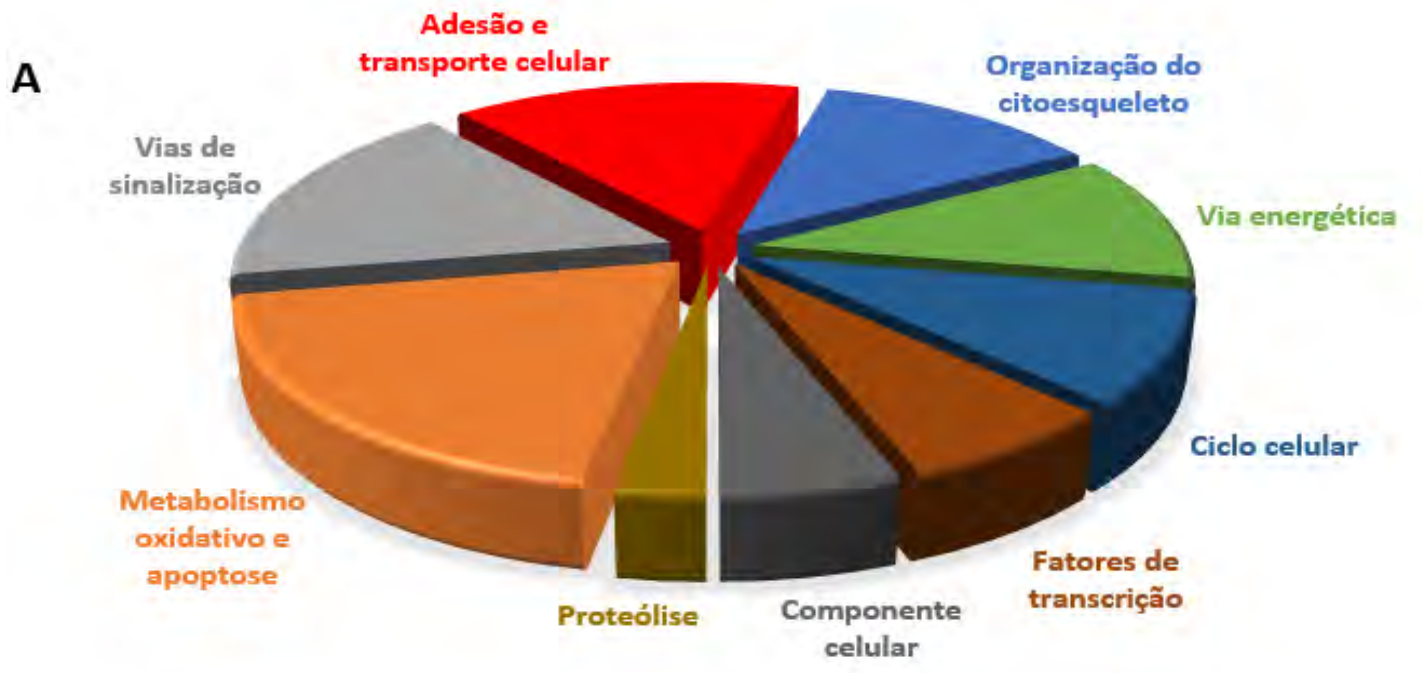

B

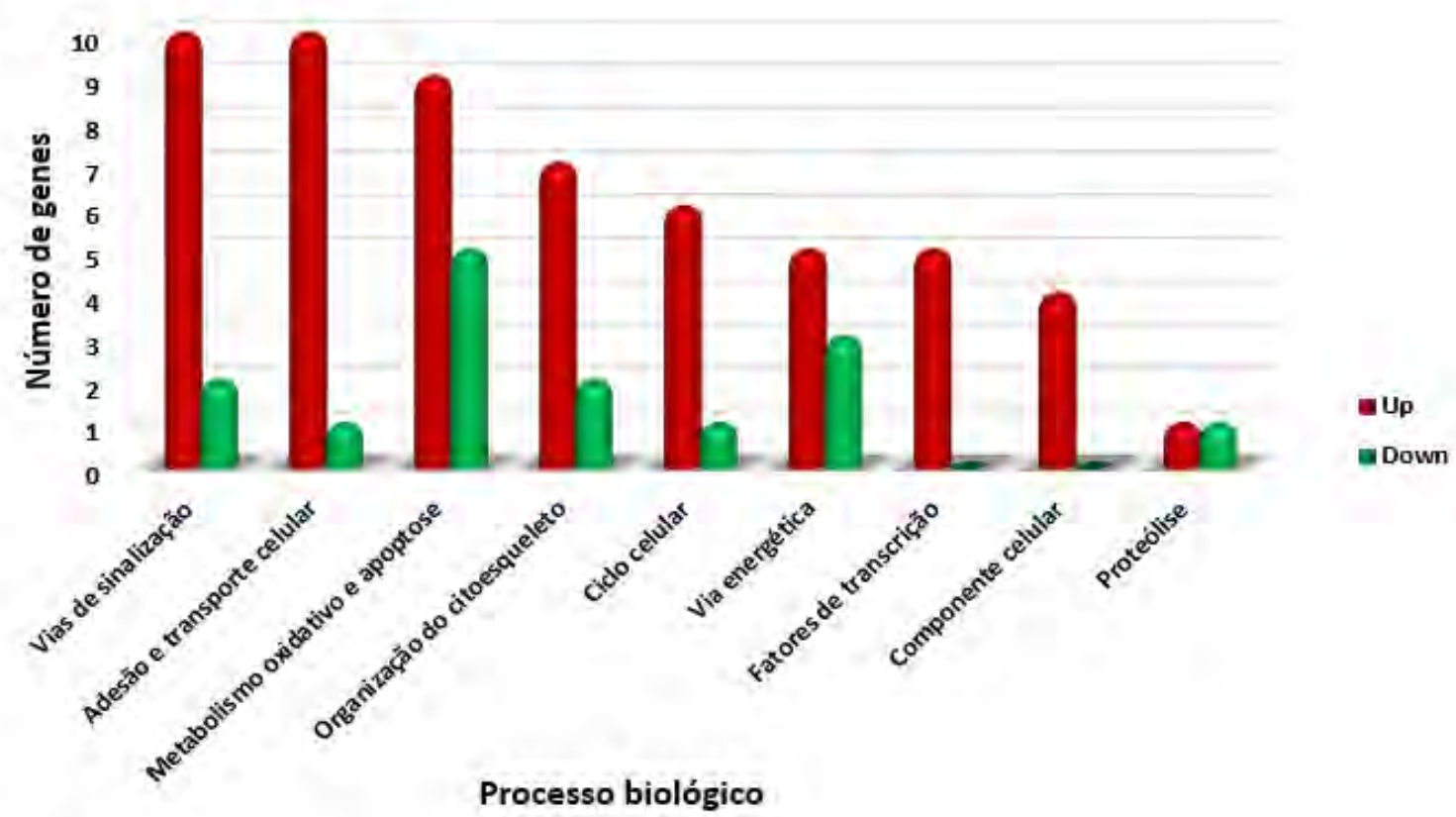

Figura 15. Análise por RNA-Seq do perfil de transcriptomas de células do cumulus oriundas de complexos cumulus-oócitos suínos maturados em meio acrescido ou não de melatonina. (A) Comparação entre os processos biológicos e funções dos transcritos dos meios com e sem adição de melatonina. (B) Número de genes e seus respectivos processos que aumentaram ou diminuíram a expressão. 


\subsection{DISCUSSÃO}

O presente estudo mostrou que a suplementação de melatonina no meio de maturação pode influenciar a proliferação celular, na medida em que modula a expressão de genes que estimulam a progressão do ciclo celular (FHL2, EPHB4, CCNG2, RAB39B, FBLIM1e KIF13B) e/ou interrompem o ciclo celular (BTG2 e WEE1). Os produtos dos genes FHL2 e EPHB4 estimulam a divisão celular por meio da ativação do complexo ciclina-CDK (MILLER et al., 1998; LABALETTE et al., 2008) e o gene CCNG2 tem como produto uma ciclina, fundamental para a formação do complexo ciclina-CDK (PADUA; HANSEN, 2010). De acordo com Askjaer et al. (2002) e Fu et al. (2011), os genes RAB39B, FBLIM1 e KIF13B são fundamentais para a formação do fuso mitótico e da carioteca, sendo que o gene KIF13B é responsável pela movimentação dos centrômeros na formação do fuso mitótico (TORRES et al., 2011).

Nosso estudo é o primeiro a mostrar o efeito da melatonina sobre a expressão de genes associados à proliferação em células do cumulus, entretanto, estudos prévios utilizando oócitos e células do cumulus de suínos (NAITO et al., 1992; MOTLIK et al., 1996), bovinos (SAKAGUCHI et al., 2002) e humanos (COMBELLES et al., 2005), mostraram que tanto o meio de cultivo quanto as condições de maturação podem influenciar o ciclo celular.

Numerosos estudos têm descrito a influência que o oócito exerce sobre as células do cumulus (GE et al., 2002; TORNER et al., 2004; WONGSRIKEAO et al., 2005; ZHANG et al., 2010). Em bovinos, foi demonstrado que a presença de oócitos contribui para a proliferação celular e reduz a apoptose de células do cumulus (HUSSENIN et al. (2005). Entretanto, são poucas as informações que descrevem os mecanismos exatos pelos quais as células do cumulus influenciam o oócito. De acordo com Brankin et al., (2003), o co-cultivo de oócitos com células da granulosa e teca, resulta em aumento da viabilidade oocitária. Além disso, Su et al. (2002), sugerem que as células do cumulus tem a habilidade de influenciar no ciclo celular do oócito. Deste modo, o estímulo a progressão nuclear e proliferação celular das células do cumulus pela adição de melatonina ao meio de 
maturação, resultaria em um microambiente mais propício para a aquisição da competência oocitária.

Em relação à influência da melatonina sobre o citoesqueleto de células do cumulus, no presente estudo, a melatonina aumentou a expressão de quatro genes associados à organização do citoesqueleto (RND1, FNBP1L, TES e FRMD4A) e três genes associados a dinâmica dos microtúbulos (TUBB3, KIF13B e MYO1B). Por outro lado, a melatonina reduziu a expressão dos genes TUBA1B e MAP1A, ambos também associados à dinâmica de microtúbulos, sugerindo que esta indolamina utiliza mecanismos antagônicos para evitar possíveis danos causados pelo excesso de estímulo.

Allworth e Albertini (1993), sugerem que as modificações no citoesqueleto de células do cumulus modulam a progressão meiótica e capacitação de oócitos bovinos. Além disso, a relatos da importância do citoesqueleto no processo de esteroidogénese em resposta a gonadotrofinas, uma vez que, o citoesqueleto influencia a morfologia e organização celular, controlando assim a síntese e secreção de esteroides (AMSTERDAM et al., 1987; BEN-ZE'EV et al., 1987; ICZKOWSKI; HERTELENDY, 1991; SASSON et al., 2004). Deste modo, o efeito da melatonina sobre o citoesquelo pode influenciar tanto na capacitação oocitária quanto na esteroidogênese das células do cumulus

A degradação de proteínas, por sua vez, mediada pela via ubiquitinaproteassoma (UPP) desempenha um importante papel na progressão do ciclo celular eucarionte, bem como, no metabolismo energético, metabolismo oxidativo, modulação de receptores e controle de fatores de transcrição (HOU et al., 2004). Trabalhos recentes sugerem que a melatonina regula genes relacionados ao UPP, tanto aumentando (KOYAMA et al., 2012; 2014), quanto reduzindo a expressão gênica (VRIEND; REITER, 2014). Nossos achados corroboram com essas observações uma vez que a melatonina aumentou a expressão do gene TRIM9, cujo produto é uma ubiquitina ligase (E3), e reduziu a expressão do gene ANKRD9, pertencente à família Ankyrin Repeat Domain, que possui afinidade pela ubiquitina e possivelmente aumenta a eficiência no processo de proteólise (BEENDERS et al., 2007; LICCHESI et al., 2011).

Em células do cumulus, a proteólise é essencial para a formação da matriz extracelular (ECM) e expansão de células do cumulus (Yl et al., 2008; 
NAGYOVA et al. 2012). De acordo com Tajima et al., (2001) e Nagyova et al. (2012), a inibição da via da UPP modula a atividade da proteína esteroidogênica StAR, aumenta a síntese e secreção de progesterona, bem como a expressão de componentes relacionados com a expansão do cumulus, em oócitos de ratos, humanos e suínos maturados in vitro.

A atividade proteossômica pode também ser essencial para o controle de qualidade durante a síntese e secreção das glicoproteínas da ECM em células do cumulus. De acordo com Yi et al. (2008), a utilização de inibidor da via UPP resulta em proteínas da ECM deformadas, o que provavelmente interfere na secreção de ácido hialurônico, responsável pela expansão das células do cumulus. Além disso, de acordo com Huo et al. (2004), o complexo UPP desempenha um papel importante na retomada da meiose oocitária, formação do fuso meiótico, emissão corpúsculo polar e na formação de prónucleos, provavelmente através da degradação da ciclina B1 e fosforilação da MAPK/p90rsk.

As moléculas de adesão celular desempenham um papel fundamental na inter-comunicação celular, uma vez que são responsáveis por gerar e manter as junções celulares (LU et al., 2003). No presente estudo a melatonina estimulou genes associados a adesão celular (FBLIM1, ZNF606, NCAM1, DSP, FNBP1L, TES, DSG2 e BTG2), transporte intra/extracelular (SLC6A15 e SLC38A1) e componentes celulares (TMEM86A, LAMB1, JUP e DSG2). Por outro lado, a melatonina reduziu a expressão dos genes AQP9 e SIDT2, cuja função principal é o transporte transmembrana (Qu et al., 2010). Embora as funções desses genes ainda não estejam totalmente claras, nossos resultados mostram, pela primeira vez, a importância da melatonina no processo de intercomunicação celular.

As células do cumulus tem papel claramente estabelecido no suporte do crescimento do oócito (BROWER; SCHULTZ, 1982), regulando a progressão da meiose (EPPIG, 1991), modulando a atividade de transcrição global no genoma oocitário (DE LA FUENTE; EPPIG 2001), e a transferência de RNA para o oócito (MACAULAY et al., 2014). A partir dos resultados encontrados no presente estudo e considerando que a aquisição da competência oocitária exige um microambiente único gerado pela regulação bidirecional entre o gameta e células somáticas circundantes (MATZUK et al., 2002), a 
suplementação com melatonina pode influenciar na intercomunicação oócito/células do cumulus, e consequentemente no desenvolvimento oocitário.

Em adição, a melatonina estimulou cinco fatores de transcrição (SOX4, AFF2, RCOR2, TRIM24 e ELK3), o que pode potencializar a resposta celular a estímulos exógenos (HUNT; CLARKE, 1999; MCGRAW et al., 2007). Os fatores de transcrição são proteínas que se ligam ao DNA de células eucarióticas para permitir que haja uma ligação entre a enzima RNA-polimerase e o DNA (EGLI et al., 2008). Em células do cumulus, assim como em outros tipos celulares, a alteração na expressão de fatores de transcrição causada pela melatonina pode contribuir para os diferentes perfis de expressão gênica.

No presente estudo observou-se que a melatonina aumentou a expressão de seis genes (PRKG2, PIP4K2A, WEE1, LPPR3, ABCA1 e PDK4) cujos produtos interferem na síntese e funcionalidade de ATP e GTP. As células do cumulus são responsáveis por fornecer ATP para o oócito (CHAPPEL, 2013). Recentemente, de acordo com Hsu et al. (2015) e Dumesic et al. (2016), a produção de ATP em células do cumulus influencia positivamente o número de oócitos maduros. Assim, o aumento na expressão de genes associados à produção de ATP em células do cumulus, sugere que a melatonina interfere nas vias metabólicas do CCOs, e consequentemente na homeostase oocitária (SUTTON et al., 2003, VAN BLERKOM, 2008). Além disso, a melatonina reduz a expressão do gene AGRP, que está ligado ao metabolismo lipídico e à produção de espécies reativas (BRANNIAN et al., 1997); essa redução pode ser benéfica à viabilidade celular uma vez que pode resultar em redução dos níveis intracelulares de ROS.

A glicogênese e a glicólise são mecanismos antagônicos e complementares, essenciais para o funcionamento celular. A melatonina regulou a expressão de seis genes relacionados ao equilíbrio glicólise/glicogênese (GNPTAB, PFKFB3, KLHL24, ENO2, PFKFB4 e UGDH), o que pode garantir a reserva energética necessária para manutenção do metabolismo celular. Os genes PFKFB3, KLHL24 e ENO2 têm como produtos, as enzimas responsáveis por manter esse equilíbrio (MA et al., 2013). Em células do cumulus a UDP-N-acetilglicosamina, produto da cascata da glicose sob ação dos genes GNPTAB, PFKFB3 e PFKFB4 (TAMMl et al., 2011; CHESNEY et al., 2014) é convertida em ácido hialurônico por meio das enzimas 
UDP-glicose 6-desidrogenase (UG6D) e ácido hialurônico sintase (HAS2) (SUTTON-MCDOWALL et al., 2010). Além disso, a enzima UG6D é produto do gene UGDH, demonstrando assim a influência da melatonina durante todo o processo energético e de expansão das células do cumulus (TAMMI et al., 2011).

O potencial antioxidante da melatonina é devido a capacidade de neutralizar de forma direta e indireta as espécies reativas, assim como regular de forma indireta o metabolismo oxidativo. No presente estudo, a melatonina: i) aumentou a expressão dos genes SLC6A15, PFKFB3 e PDK4. SLC6A15 e PFKFB3, que apresentam características antioxidantes (SEO; LI, 2014), e ii) aumentou a expressão de PDK4, que pode previnir a peroxidação lipídica (ZHANG et al., 2014). Além disso, a melatonina reduziu a ação dos genes oxidantes FMO1, WNT5A, AGRP e CYB5A. O gene FMO1 está envolvido no metabolismo oxidativo dependente de $\mathrm{NADPH}$, promovendo aumento na produção de ROS (CHEN; UMEDA, 2015). O gene WNT5A está envolvido no aumento da resposta inflamatória e do estresse oxidativo (ZHAO et al., 2015). O gene AGRP promove acúmulo de lipídeos, favorecendo a peroxidação lipídica (BRANNIAN et al., 1997). O gene CYB5A age no metabolismo de ácidos graxos, favorecendo a formação de espécies reativas (BAYNE et al., 2013).

De acordo com Tamura et al. (2012), o equilíbrio entre as ROS e os antioxidantes, parece ser essencial para a manutenção do oócito e das células do cumulus/ granulosa. Deste modo, considerando a intercomunicação entre as células do cumulus e o oócito, é plausível admitir que o potencial antioxidante da melatonina nas células do cumulus pode favorecer a aquisição da competência oocitária. Entretanto, o potencial antioxidante da melatonina favoreceria especialmente a viabilidade celular evitando assim os danos causados pelas espécies reativas tanto nas células do cumulus quanto no oócito.

Estudos prévios relatam a capacidade da melatonina em reduzir a expressão de genes pró-apoptóticos (BAX e caspase-3) e aumentar a expressão do gene anti-apoptótico (Bcl-2), acompanhado por um aumento de níveis intracelulares de glutationa e redução na produção das ROS (REITER et al., 2009; GAO et al., 2012; MOHSENI et al., 2012). No presente estudo foi 
verificado que a melatonina estimula expressão dos genes anti-apoptóticos KLF4, RSPO2, FHL2 e BTG2 em acordo com os estudos de Cao et al. (2012); Li et al. (2009) e Labalette et al. (2008). De acordo com Alisch et al. (2003) a taxa de apoptose em células de cumulus pode ser considerada como um indicador da qualidade oocitária, sendo que uma baixa taxa de apoptose em células cumulus está correlacionada diretamente com a aquisição da competência oocitária e embriões de boa qualidade. Considerando a característica anti-apoptótica da melatonina, o aumento da expressão do gene pró-apoptótico MAP4K4 provavelmente está associado a homeostase celular. De acordo com Kimball et al. (2008), a produção de espécies reativas pelo MAP4K4 seria degradada por meio dos outros mecanismos de defesa antioxidante da melatonina. Entretanto, serão necessários maiores estudos para verificar o mecanismo pelo qual a melatonina se torna um agente antiapoptótico em células normais e pró-apoptóticos em células cancerígenas (MIN et al., 2012; SÁNCHEZ-HIDALGO et al., 2012).

Deste modo, o presente estudo é o primeiro a relatar o efeito da melatonina sobre a expressão de genes associados a diversos processos biológicos (Figura 16) em células do cumulus suínas maturadas in vitro. Por outo lado, aponta a necessidade de aprofundamento dos conhecimentos referentes aos mecanismos de ação dessa indolamina.

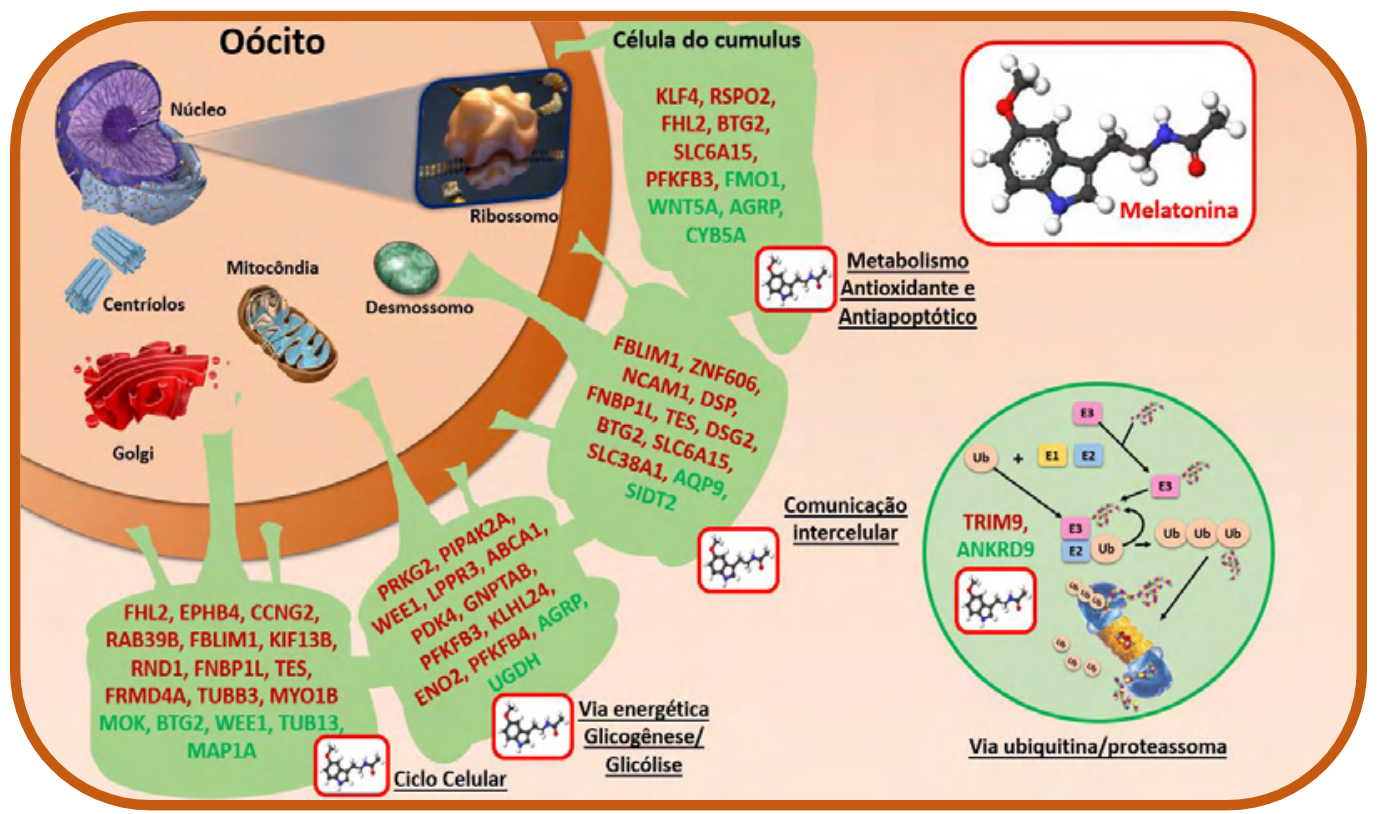

Figura 16. - Mecanismos de ação indireta da melatonina sobre a expressão gênica no complexo cumulus-oócito 


\section{REFERENCIAS}

ALBERTS B., JOHNSON A., LEWIS J., RAFF M., ROBERTS K., WALTER P. Molecular Biology of the Cell. 5th ed. New York: Garland Science; 2007.

ANDERS S, HUBER W. 2010.Differential expression analysis for sequence count data. Genome Biology, 11, R106.

ASKJAER P, GALY V, HANNAK E, MATTAJ IW. Ran GTPase cycle and importins alpha and beta are essential for spindle formation and nuclear envelope assembly in living Caenorhabditis elegans embryos. Molecular Biology of the Cell. v. 13, n. 12, p. 4355-70, 2002.

BARLOW-WALDEN LR, REITER RJ, ABE M, PABLOS M, MENENDEZPELAEZ A, CHEN LD, POEGGELER B: Melatonin stimulates brain glutathione peroxidase activity. Neurochemistry International, v. 26, n. 5, p. 497-502, 1995

BAYNE RA, FORSTER T, BURGESS ST, CRAIGON M, WALTON MJ, BAIRD DT, GHAZAL P. Molecular Profiling of the Human Testis Reveals Stringent Pathway-Specific Regulation of RNA Expression Following Gonadotropin Suppression and Progestogen Treatment. Journal of Andrology, v. 29, n. 4, 2008

BEENDERS B, JONES P, BELLINI M. The Tripartite Motif of Nuclear Factor 7 is required for its association with transcriptional units. Molecular and Cellular Biology, v. 27, n. 7, p. 2615-2624, 2007.

BENJAMINI Y, HOCHBERG Y. Controlling the false discovery rate: a practica and powerful approach to multiple testing". Journal of the Royal Statistical Society, Series B, v. 57, p. 289-300, 1995.

BRANNIAN J. ZHAO Y, BURBACH J. Localization of lipid peroxidation-derived protein epitopes in the porcine corpus luteum. Biology of Reproduction, v. 57, p. 1461-1466, 1997.

CAO Q, ZHANG X, LU L, YANG L, GAO J, GAO Y, MA H, CAO Y. Klf4 is required for germ-layer differentiation and body axis patterning during Xenopus embryogenesis. Development, v. 139, p. 3950-3961, 2012

CARPENTIERI, A., DÍAZ DE BARBOZA, G., ARECO, V., PERALTA LÓPEZ, M., TOLOSA DE TALAMONI, N. New perspectives in melatonin uses. Pharmacological Research, v. 65, p. 437-44, 2012. 
CASAO A, ABECIA, J, CEBRIÁN-PÉREZ A, MUIÑO-BLANCO T. The effects of melatonin on in vitro oocyte competence and embryo development in sheep. Spanish Journal of Agricultural Research 8(1), 35-41, 2010.

CHEN, Y.C., SHEEN, J.M., TIAO, M.M., TAIN, Y.L., HUANG, L.T. Roles of melatonin in fetal programming in compromised pregnancies. International Journal of Molecular Sciences, v. 6, p. 5380-5401, 2013.

CHEN P, UMEDA M.DNA doublestrand breaks induce the expression of flavincontaining monooxygenase and reduce root meristem size in Arabidopsis thaliana. Genes to Cells, v. 20, n. 8, p. 636-646, 2015.

CHESNEY J, CLARK J, KLARER AC, IMBERT-FERNANDEZ Y, LANE AN, TELANG S. Fructose-2,6-bisphosphate synthesis by 6-phosphofructo-2kinase/fructose-2,6-bisphosphatase 4 (PFKFB4) is required for the glycolytic response to hypoxia and tumor growth. Oncotarget, v. 30, n. 5, p. 6670-6686, 2014.

EL-RAEY, M., GESHI, M., SOMFAI, T., KANEDA, M., HIRAKO, M., ABDELGHAFFAR, A.E., SOSA, G.A., ABAU EL-ROOS, M.E.A., NAGAI, T. Evidence of melatonin synthesis in the cumulus oocyte complexes and its role in enhancing oocyte maturation in vitroin cattle. Molecular Reproduction and Development, v.78, p. 250-262, 2011.

FISCHER, T.W., KLESZCZYŃSKI, K., HARDKOP, L.H., KRUSE, N., ZILLIKENS, D. Melatonin enhances antioxidative enzyme gene expression (CAT, GPX, SOD), prevents their UVR-induced depletion, and protects against the formation of DNA damage (8-hydroxy-2'-deoxyguanosine) in ex vivo human skin. Journal of Pineal Research, v. 54, p. 303-312, 2013.

FU W, JIANG Q, ZHANG C. Novel functions of endocytic player clathrin in mitosis. Cell Research, v. 21, n. 12, p. 1655-1661, 2011.

GALANO A, TAN DX, REITER RJ. On the free radical scavenging activities of melatonin's metabolites, AFMK and AMK. Journal of Pineal Research, v. 54, n. 3, p. 245-257, 2013.

GAO C, HAN HB, TIAN XZ, TAN DX, WANG L, ZHOU GB, ZHU SE, LIU GS. Melatonin promotes embryonic development and reduces reactive oxygen species in vitrified mouse 2-cell embryos. Journal of Pineal Research, v. 52, n. 3, p. 305-311, 2012.

GENTLEMAN R, CAREY VJ, BATES DM, BOLSTAD B, DETTLING M, DUDOIT S, ELLIS B, GAUTIER L, GE Y. Bioconductor: Open software development for computational biology and bioinformatics R. Genome Biology, v. 5, R80, 2004. 
HARDELAND, R., CARDINALI, D.P., SRINIVASAN, V., SPENCE, D.W., BROWN, G.M., PANDI-PERUMAL, S.R. Melatonin-a pleiotropic, orchestrating regulator molecule. Progress in Neurobiology, v. 93, p. 350-384, 2011.

HOCHEGGER H, KLOTZBUCHER A, KIRK J, HOWELL M, LEGUELLEC K, FLETCHER K, DUNCAN T, SOHAIL M, HUNT T: New B-type cyclin synthesis is required between meiosis I and II during Xenopus oocyte maturation. Development, v.128, p. 3795-3807, 2001.

HUO LJ, FAN HY, LIANG CG, YU LZ, ZHONG ZS, CHEN DY, SUN QY. Regulation of ubiquitin-proteasome pathway on pig oocyte meiotic maturation and fertilization. Biology of Reproduction, v. 71, n. 3, p. 853-862, 2004a.

HUO LJ, FAN HY, ZHONG ZS, CHEN DY, SCHATTEN H, SUN QY. Ubiquitinproteasome pathway modulates mouse oocyte meiotic maturation and fertilization via regulation of MAPK cascade and cyclin B1 degradation. Mechanisms of Development, v. 121, n. 10, p. 1275-87, 2004b.

KIMBALL SR, ABBAS A, JEFFERSON LS. Melatonin represses oxidative stress-induced activation of the MAP kinase and mtor signaling pathways in H4IIE hepatoma cells through inhibition of Ras. Journal of Pineal Research, v. 44, n. 4, p 379-386, 2008.

KING, G. Melatonin as a cytoskeletal modulator: implications for cell physiology and disease. Journal of Pineal Research, v. 40, p. 1-9, 2006.

KISHIMOTO T. Cell-cycle control during meiotic maturation. Current Opinion in Cell Biology, v. 15, p. 654-663, 2003.

KORKMAZ, A., ROSALES-CORRAL, S., REITER, R.J. Gene regulation by melatonin linked to epigenetic phenomena. Gene, v.503, p. 1-11, 2012.

KOYAMA FC, RIBEIRO RY, GARCIA JL, AZEVEDO MF, CHAKRABARTI D, GARCIA CR. Ubiquitin proteasome system and the atypical kinase PfPK7 are involved in melatonin signaling in Plasmodium falciparum. Journal of Pineal Research, v. 53, n. 2, p. 147-53, 2012.

KOYAMA FC, AZEVEDO MF, BUDU A, CHAKRABARTI D, GARCIA CR. Melatonin-induced temporal up-regulation of gene expression related to ubiquitin/proteasome system (UPS) in the human malaria parasite Plasmodium falciparum. International Journal of Molecular Sciences, v. 15, n. 12, 22320-22330, 2014.

LABALETTE C, NOUËT Y, SOBCZAK-THEPOT J, ARMENGOL C, LEVILLAYER F, GENDRON MC, RENARD CA, REGNAULT B, CHEN J, BUENDIA MA, WEI Y. The LIM-only protein FHL2 regulates cyclin D1 
expression and cell proliferation. The Journal of Biological Chemistry, v. 30;283(22), 2008.

LERNER, A.B., CASE, J.D., TAKAHASHI, Y., LEE, Y., MORI, W. Isolation of melatonin, the pineal factor that lightens melanocytes. Journal of the American Chemical Society, v. 80, p. 2587, 1958.

LERNER, A.B., CASE, J.D., HEINZELMANN, R.V. Structure of melatonin. Journal of the American Chemical Society, v. 81, p. 6084-6085, 1959.

Li H, Handsaker B, Wysoker A, Fennell T, Ruan J, Homer N, Marth G, Abecasis G, Durbin R. and 1000 Genome Project Data Processing Subgroup. The Sequence alignment/map (SAM) format and SAMtools. Bioinformatics, v. 25, p. 2078-2079, 2009.

LICCHESI JD, MIESZCZANEK J, MEVISSEN TE, RUTHERFORD TJ, AKUTSU M, VIRDEE S, EL OUALID F, CHIN JW, OVAA H, BIENZ M, KOMANDER D. An ankyrin-repeat ubiquitin-binding domain determines TRABID's specificity for atypical ubiquitin chains. Nature Structural \& Molecular Biology, v. 19, n. 1, p. 62-71 2011.

LONERGAN, P.; MONAGHAN, P.; RIZOS, D.Effect of follicle size on bovine oocyte quality and development competence following maturation, fertilization and culturein vitro.Molecule Reproduction Development, v. 37, p. 48 -53, 1994.

LOVE MI, HUBER W, ANDERS S. 2014. Moderated estimation of fold change and dispersion for RNA-Seq data with DESeq2. bioRxiv. http://dx.doi.org/10.1101/002832.

LU DP, TIAN L, O'NEILL C, KING NJ. Regulation of cellular adhesion molecule expression in murine oocytes, peri-implantation and post-implantation embryos. Cell Research. v. 12, p. 373-383, 2002.

MA JY, LI M, LUO YB, SONG S, TIAN D, YANG J, ZHANG B, HOU Y, SCHATTEN H, LIU Z, SUN QY. Maternal factors required for oocyte developmental competence in mice: transcriptome analysis of non-surrounded nucleolus (NSN) and surrounded nucleolus (SN) oocytes. Cell Cycle. v. 12, n. 12, p. 1928-1938, 2013.

MANJUNATHA, B.M., DEVARAJ, M., GUPTA, P.S.P., RAVINDRA, J.P., NANDI, S. Effect of taurine and melatonin in the culture medium on buffalo in vitro embryo development. Reproduction in Domestic Animals, v. 44, p. $12-$ 16, 2009. 
MANNA PR, STOCCO DM. The role of specific mitogen-activated protein kinase signaling cascades in the regulation of steroidogenesis. Journal of Signal Transduction, v. 2011:821615, 2011.

MATIKAINEN, T., PEREZ, G.I., ZHENG, T.S., KLUZAK, T.R., RUEDA, B.R., FLAVELL, R.A., TILLY, J.L. Caspase-3 gene knockout defines cell lineage specificity for programmed cell death signaling in the ovary. Endocrinology, v. 142, p. 2468-2480, 2001.

MILLER JW, SELHUB J, JOSEPH JA. Oxidative damage caused by free radicals produced during catecholamine autoxidation: protective effects of $\mathrm{O}$ methylation and melatonin. Free Radical Biology and Medicine. v. 21, n. 2, p. 241-249, 1996.

MOHSENI, M., MIHANDOOST, E., SHIRAZI, A., SEPEHRIZADEH, Z., BAZZAZ, J.T., GHAZI-KHANSARI, M. Melatonin may play a role in modulation of bax and bcl-2 expression levels to protect rat peripheral Blood lymphocytes from gamma irradiation-induced apoptosis. Mutation Research. v. 739, p. 1927, 2012.

NEEFJES J, GROOTHUIS TA, DANTUMA NP. The 2004 Nobel Prize in Chemistry for the discovery of ubiquitin-mediated protein degradation. Nederlands Tijdschrift voor Geneeskunde, v. 148, n. 52, p. 2579-2582, 2004.

NIGG EA: Mitotic kinases as regulators of cell division and its checkpoints. Nature Reviews Molecular Cell Biology, v. 2, p. 21-32, 2001.

PADUA MB, HANSEN PJ. Evolution and function of the uterine serpins (SERPINA14). American Journal of Reproductive Immunology. v. 64, n. 4, p. 265-274, 2010.

QIAN YW, ERIKSON E, TAIEB FE, MALLER JL: The polo-like kinase PIx1 is required for activation of the phosphatase Cdc25C and cyclin-B-Cdc2 in Xenopus oocytes. Molecular Biology of the Cell, v.12, p. 1791-1799, 2001.

QU F, WANG FF, LU XE, DONG MY, SHENG JZ, LV PP, DING GL, SHI BW, ZHANG D, HUANG HF. Altered aquaporin expression in women with polycystic ovary syndrome: hyperandrogenism in follicular fluid inhibits aquaporin-9 in granulosa cells through the phosphatidylinositol 3-kinase pathway. Human Reproduction, v. 25, n. 6, p. 1441-1450, 2010.

REITER, R.J., TAN, D.X., MANCHESTER, L.C., EL-SAWI, M.R. Melatonin reduces oxidant damage and promotes mitochondrial respiration: implications for aging. Annals of the New YorkAcademy of Sciences, v. 959, p. 238250, 2002. 
REITER, R.J., TAN, D.X., MANCHESTER, L.C., PAREDES, S.D., MAYO, J.C., SAINZ, R.M. Melatonin and reproduction revisited. Biology of Reproduction, v.81, p. 445-456, 2009.

REITER, R.J. Melatonin: Lowering the high price of free radicals. News in Physiological Sciences, v.15, p. 246-250, 2000.

ROBINSON MD, MCCARTHY DJ, SMYTH GK. EdgeR: a bioconductor package for differential expression analysis of digital gene expression data. Bioinformatics v. 26, p. 139-140, 2010.

ROBINSON MD, OSHLACK A. A scaling normalization method for differential expression analysis of RNA-seq data. Genome Biology, v. 11:R25, 2010.

RODRIGUEZ, C., MAYO, J.C., SAINZ, R.M., ANTOLIN, I., HERRERA, F., MARTIN, V., REITER, R.J. Regulation of antioxidant enzymes: A significant role for melatonin. Journal of Pineal Research, v. 36, p. 1-9, 2004.

RODRIGUEZ KF, BLOMBERG LA, ZUELKE KA, MILES JR, ALEXANDER JE, FARIN CE. Identification of candidate $m R N A s$ associated with gonadotropininduced maturation of murine cumulus oocyte complexes using serial analysis of gene expression. Physiological Genomics, v. 27, n. 3), p. 318-27, 2006.

SCHMITT A, NEBREDA AR: Inhibition of Xenopus oocyte meiotic maturation by catalytically inactive protein kinase A. Proceedings of the National Academy of Sciences, v.99, p. 4361-4366, 2002.

SEO M, LI Y-H. PFKFB3 regulates oxidative stress homeostasis via its Sglutathionylation in cancer. Journal of Molecular Biology, v. 426, n. 4, p. 830-842, 2014.

SHI, J.M., TIAN, X.Z., ZHOU, G.B., WANG, L., GAO, C., ZHU, S.E., ZENG, S.M., TIAN, J.H.,LIU, G.S. Melatonin exists in porcine follicular fluid and improves in vitro maturation and parthenogenetic development of porcine oocytes. Journal of Pineal Research, v. 47, p. 318-323, 2009.

SOLC P, SCHULTZ RM, MOTLIK J. Prophase I arrest and progression to metaphase I in mouse oocytes: comparison of resumption of meiosis and recovery from G2-arrest in somatic cells. Molecular Human Reproduction. v. 16, n. 9, p. 654-664, 2010.

SUTTON-MCDOWALL ML, GILCHRIST RB, THOMPSON JG. The pivotal role of glucose metabolism in determining oocyte developmental competence. Reproduction. v. 139, n. 4, p. 685-695, 2010. 
TAMMI RH, PASSI AG, RILLA K, KAROUSOU E, VIGETTI D, MAKKONEN K, TAMMI MI. Transcriptional and post-translational regulation of hyaluronan synthesis. FEBS Journal. v. 278, n. 9, p. 1419-1428, 2011.

TAMURA, H., NAKAMURA, Y., KORKMAZ, A., MANCHESTER, L.C., TAN, D.X., SUGINO, N., REITER, R.J. Melatonin and the ovary: Physiological and pathophysiological implication. Fertility and Sterility, v. 92, p. 328-343, 2009.

TAN, D.X., CHEN, L.D., POEGGELER, B., MANCHESTER, L.C., REITER, R.J. Melatonin: a potent endogenous hydroxyl radical scavenger. Endocrine Journal, v. 1, p. 57-60, 1993.

TAN, D.X., REITER, R.J., MANCHESTER, L.C., YAN, M.T., EL SAWI, M., SAINZ, R.M., MAYO, J.C., KOHEN, R., ALLEGRA, M., HARDELAND, R. Chemical and physical properties and potential mechanisms: melatonin as a broad-spectrum antioxidant and free radical scavenger. Current Topics in Medicinal Chemistry, v. 2, p. 181-197, 2002.

TORRES JZ, SUMMERS MK, PETERSON D, BRAUER MJ, LEE J, SENESE $S$, GHOLKAR AA, LO YC, LEI X, JUNG K, ANDERSON DC, DAVIS DP, BELMONT L, JACKSON PK. The STARD9/Kif16a kinesin associates with mitotic microtubules and regulates spindle pole assembly. Cell, v. 147, n. 6, p. 1309-1323, 2011.

TRAPNELL C, PACHTER L, SALZBERG SL. TopHat: discovering splice junctions with RNA-Seq. Bioinformatics, v. 25, p. 1105-1111, 2009.

VRIEND J, REITER RJ. Melatonin and ubiquitin: what's the connection? Cellular and Molecular Life Sciences. v. 71, p. 3409-3418, 2014.

ZHANG Y, DUAN X, CAO R, LIU HL, CUI XS, KIM NH, RUI R, SUN SC. Small GTPase RhoA regulates cytoskeleton dynamics during porcine oocyte maturation and early embryo development. Cell Cycle. v.13, n. 21, p. 3390403, 2014.

ZHAO D, XU A, DAI Z, PENG J, ZHU M, SHEN J, ZHENG Q, RAN Z. WNT5A transforms intestinal $C D 8 \alpha \alpha(+)$ IELs into an unconventional phenotype with pro-inflammatory features. BMC Gastroenterology, v. 15, n. 1, p.173, 2015. 


\section{CAPÍTULO V}

\section{O efeito da melatonina sobre a} expressão de genes em células do cumulus associados à viabilidade oocitária: a análise de transcrição gênica 


\section{Resumo}

O objetivo desse estudo foi avaliar o efeito da melatonina sobre os genes associados à viabilidade oocitária e ao subsequente desenvolvimento embrionário por meio da análise do perfil de trascriptomas de células do cumulus suínas, via RNA-Seq. Células do cumulus oriundas de 240 complexos cumulus-oócitos (CCOs) suínos maturadas in vitro com ou sem $10^{-9} \mathrm{M}$ de melatonina, foram armazenadas a $-80^{\circ} \mathrm{C}$ até serem submetidas à extração de RNA. O preparo das bibliotecas foi realizado conforme o protocolo TruSeq $R N A$, o mapeamento das amostras foi feito contra o genoma de Sus scrofa e posteriormente os arquivos de mapeamento foram analisados. Após obtenção das contagens, nos grupos com ou sem melatonina, os dados foram submetidos à análise de expressão diferencial. A adição da melatonina ao meio de maturação influenciou na expressão de 59 genes (adjusted $P$-value $<0.05$; fold change $>2$ ) associados a nove funções biológicas (expansão do cumulus, comunicação entre células do CCOs, maturação nuclear, maturação citoplasmática, reparo e integridade do DNA, viabilidade oocitária, esteroidogênese, fertilização e embriogênese). A melatonina aumentou a expressão de genes associados à maturação nuclear (FHL2, EPHB4, CCNG2, RAB39B, FBLIM1, KIF13B, ACVR1, CLK1 e OSGIN2) e maturação citoplasmática (RND1, FNBP1L, TES, FRMD4A, TUBB3, KIF13B e MYO1B). A melatonina também aumentou a expressão dos genes APFL, SOX4 e RCOR2, associados ao reparo ou remodelamento de DNA através de mecanismos epigenéticos. Além disso, a melatonina aumentou a expressão de genes associados à fertilização, embriogênese e organogênese (ZNF606, NCAM1, DSP, TES, LAMB1, KLF4, NCAM1 e GATA-3). Conclui-se que a suplementação do meio de maturação com melatonina resulta em aumento do transcriptoma de um número expressivo de genes associados à aquisição da competência oócitária bem como da viabilidade embrionária e do subsequente desenvolvimento embrionário.

Palavras-chave: reprodução, ovário, células germinativas, transcriptoma. 


\subsection{INTRODUÇÃO}

A comunicação bidirecional entre o oócito e as células do cumulus (CC) é crucial para o desenvolvimento do folículo ovariano e está intimamente ligada com à viabilidade oocitária (ZHOU et al., 2016). A inter-relação de dois tipos celulares requer uma coordenação precisa, regulada por meio de mecanismos parácrinos de sinalização durante a foliculogênese (FENG et al., 2013; SANTIQUET et al., 2012). As células do cumulus, por meio das junções comunicativas, transferem pequenos metabólitos (VAN SOOM et al., 2002), fatores parácrinos (HUSSEIN et al., 2006) e até mesmo RNAm (MACAULAY et al., 2014) para o oócito.

As biotécnicas artificiais da reprodução, em especial, a maturação in vitro de oócitos, possibilita investigação dos fatores e mecanismos envolvidos na aquisição da competência oocitária. Entretanto, as células germinativas, em microambiente in vitro, sofrem com os danos causados pelo extresse oxidativo (SOMFAl et al., 2007; ALI et al., 2003), o que resulta em baixa viabilidade oocitária e, consequentemente, baixas taxas de desenvolvimento embrionário (KHALIL et al., 2013).

Estudos têm demonstrado a habilidade da melatonina de aumentar a viabilidade oocitária e combater os radicais livres (CHOl et al., 2008; KANG et al., 2009; SHI et al., 2009, NAKANO et al., 2012; VARGAS et al., 2011; WANG et al., 2013). Esta indolamina protege o DNA nuclear e mitocondrial, além de ácidos graxos e proteínas dos danos induzidos por radicais livres (REITER et al., 2000); e indiretamente, mostra-se capaz de regular a expressão de genes associados à esteroidogênese (CYP11A, CYP17 e StAR) (ADRIAENS et al., 2006; Wu et al., 2001). Por outro lado, os mecanismos e as vias, pelas quais essa indolamina age ainda permanecem pouco conhecidos.

Desta forma, o objetivo desse estudo foi avaliar o efeito da melatonina sobre os genes associados à viabilidade oocitária e ao desenvolvimento embrionário subsequente por meio da análise do perfil de trascriptomas de células do cumulus oriundas de complexos cumulus-oócitos (CCOs) suínos maturados in vitro via RNA-Seq. 


\subsection{MATERIAL E MÉTODOS}

\subsubsection{Local do experimento}

A coleta das amostras e extração do RNA foram realizadas nos Laboratórios de Reprodução Animal e Genética da EMBRAPA Suínos e Aves, Unidade de Concórdia - Santa Catarina e o preparo das bibliotecas e sequenciamento dos transcritos foram realizados no Laboratório de Biotecnologia Animal - LZT da ESALQ/USP, Piracicaba - São Paulo.

\subsubsection{Obtenção e seleção dos complexos cumulus-oócitos}

Foram utilizados complexos cumulus-oócitos (CCOs) oriundos de ovários suínos coletados post-mortem em abatedouros comerciais. Os ovários foram acondicionados em garrafas térmicas, mantidos a temperatura de $30-33^{\circ} \mathrm{C}$ e transportados para o laboratório. Antes da aspiração, os ovários foram lavados com solução salina a temperatura de $33^{\circ} \mathrm{C}$. O líquido de folículos de 3 a $8 \mathrm{~mm}$ foi aspirado com seringa descartável, com agulha $20 \mathrm{G}$ e depositado em tubos cônicos de $50 \mathrm{~mL}$ mantidos em banho-maria a $33^{\circ} \mathrm{C}$. Terminada a aspiração, os tubos foram mantidos em repouso por 15 minutos para a sedimentação. Os complexos CCOs foram localizados e depositados em meio de lavagem [TCM199 com Hepes Sódico (10mM), Hepes Ácido (10mM), bicarbonato de sódio $(250 \mathrm{mM})$, PVA $(0,1 \mu \mathrm{L} / \mathrm{ml})$, piruvato de sódio $(2,2 \mu \mathrm{g} / \mathrm{ml})$, amicacina $(16,67$ $\mu \mathrm{g} / \mu \mathrm{l})]$.

\subsubsection{Maturação in vitro}

Os CCOs selecionados foram lavados uma vez em meio de lavagem (Tabela 4). Posteriormente, foram distribuídos aleatoriamente, de acordo com os tratamentos:

- Grupo PVA: os oócitos foram lavados em meio de maturação TCM199 suplementado com 0,1\% de PVA (Tabela 5). Em seguida, grupos de 20 a 25 oócitos foram transferidos para microgotas de $100 \mu \mathrm{L}$ de meio de 
maturação sob óleo mineral em placa de Petri de $35 \mathrm{~mm}$. Os oócitos foram maturados em estufa úmida a $38,5^{\circ} \mathrm{C}$ em atmosfera contendo baixa tensão de oxigênio ( $5 \%$ de $\mathrm{O}_{2}, 5 \%$ de $\mathrm{CO}_{2}$ e $90 \%$ de $\mathrm{N}_{2}$ ).

- Grupo PVA + MEL: os oócitos foram lavados em meio de maturação TCM199 suplementado com 0,1\% de PVA (Tabela 5), acrescido com 10${ }^{9} \mathrm{M}$ de melatonina. Em seguida, grupos de 20 a 25 oócitos foram transferidos para microgotas de $100 \mu \mathrm{L}$ de meio de maturação sob óleo mineral em placa de Petri de $35 \mathrm{~mm}$. Os oócitos foram maturados em estufa úmida a $38,5^{\circ} \mathrm{C}$ em atmosfera contendo baixa tensão de oxigênio ( $5 \%$ de $\mathrm{O}_{2}, 5 \%$ de $\mathrm{CO}_{2}$ e $90 \%$ de $\mathrm{N}_{2}$ ).

Depois de decorridas 22 horas de maturação, os oócitos foram transferidos para microgotas dos respectivas atmosferas e meios de maturação sem hormônios, com ou sem adição de $10^{-9} \mathrm{M}$ de melatonina, de acordo com o tratamento, nos quais permaneceram por mais 22 horas.

\subsubsection{Extração de RNA e sequenciamento}

Para verificar a ação da melatonina por RNA-seq foram coletadas células do cumulus oriundas de 240 CCOs suínos divididas em dois tratamentos (com e sem melatonina), em três repetições. Os oócitos e as células do cumulus foram separados por meio de sucessivas pipetagens em meio de lavagem. As células do cumulus foram lavadas três vezes em meio de lavagem, transferidas para criotubos e mergulhadas no nitrogênio líquido. Todas as amostras foram armazenadas a $-80^{\circ} \mathrm{C}$ até serem submetidas à extração de RNA com o Kit RNA PicoPure ${ }^{\circledR}$. O RNA extraído foi depois armazenado à $-80^{\circ} \mathrm{C}$ até o momento do transporte em gelo seco para o sequenciamento. Para a técnica de sequenciamento, o RNA foi quantificado utilizando o fluorímetro Qubit $\AA^{\circledR}$ seguido de uma avaliação qualitativa utilizando o BioAnalizer ${ }^{\circledR}$. Após o preparo das bibliotecas foi feita uma análise de integridade utilizando o BioAnalizer ${ }^{\circledR}$, e tiveram sua diluição ajustada, utilizando PCR de tempo real, e foram colocadas no sequenciador.

5.2.6. Análise dos dados 
A etapa de obtenção dos dados brutos obtidos após o sequenciamento foi feita pelo software CASAVA 1.8.2, Illumina, por meio do qual o base call dos dados brutos foi transformado em reads no formato fastq acompanhados dos scores de qualidade phred. Os reads foram visualizados utilizando o programa FastQC v-0.11.3 (www.bioinformatics.bbsrc.ac.uk/ projects/).

A filtragem dos reads de baixa qualidade, sequências de adaptadores e vetores foi realizada pelo programa Seqyclean (https://bitbucket.org/izhbannikov/seqyclean), utilizando como cutoff bases com qualidade inferior a 26QScore. A base de dados de contaminantes usada foi a Univec (http://www.ncbi.nlm.nih.gov/vecscreen/univec.html). Após filtragem, reads com comprimento inferior a $65 \mathrm{pb}$ foram removidos.

\section{Mapeamento}

O mapeamento das amostras foi feito contra o genoma de Sus scrofa (Sscrofa10.2 -Ensembl), utilizando o programa TopHat v-2.1.0 (TRAPNELL et al 2009). A qualidade do mapeamento foi analisada para cada amostra utilizando o pacote Samtools v.1.2 (ferramenta flagstat, Ll et al., 2009). Os arquivos de mapeamento foram analisados pelo script do HTSeq-count v.0.6.1 (http://wwwhuber.embl.de/users/anders/htseq/doc/index.html) para extração de contagens brutas dos reads por gene.

Análise de expressão

Após obtenção das contagens, os grupos foram analisados usando o script dentro do programa DESeq2 (LOVE et al., 2014), um pacote do R/Bioconductor (GENTLEMAN et al., 2004). Por meio do programa DESeq2, os dados foram normalizados pelo tamanho das bibliotecas. Foram utilizados como background os genes que passaram pela filtragem do baseMean $>5$, resultando em 13.298 genes do total de 25.322 genes anotados. Em seguida, as contagens normalizadas dos genes que passaram na filtragem foram 
analisadas de acordo com um modelo de binomial negativo para obtenção do log2foldchange. Sobre o teste foi aplicada a correção de FDR- BenjaminiHochberg (BENJAMINI; HOCHBERG, 1995) para múltiplos testes a fim de evitar os erros tipo I, ou seja, os falsos positivos.

Para o pacote edge R - Empirical analysis of digital gene expression data in $R$ (ROBINSON et al., 2010), os dados de cada grupo foram normalizados utilizando TMM (ROBINSON; OSHLACK, 2010) usando a função calcNormFactors. Para evitar artefatos com genes de baixa contagem, após a normalização apenas foram usados os genes com CPM (counts-per-million) > 1 para metade das amostras. A análise de expressão diferencial foi realizada usando a função negativa binomial, assim como foi aplicada a correção de Benjamini-Hochberg (BENJAMINI; HOCHBERG, 1995) para múltiplos testes a fim de evitar falsos positivos. Após a análise de expressão diferencial os genes foram classificados de acordo com sua função. $O$ reconhecimento da função do transcrito foi realizado utilizando o respectivo gene ortólogo.

\subsection{RESULTADOS}

Do total de 25.322 genes anotados, 13.298 passaram pela filtragem do baseMean $>5$ (background) e 11.282 apresentaram CPM $>1$ para metade das amostras. Na análise de expressão diferencial foram identificados 80 genes que tiveram sua expressão influenciada pela adição da melatonina ao meio de maturação (adjusted $P$-value $<0.05$; fold change $>2$ ). Destes genes, 76 foram associados à viabilidade oocitária e ao desenvolvimento embrionário. A análise do perfil de transcriptomas demonstrou diferença individual e entre tratamentos na expressão dos genes (Figura 17)..

A melatonina influenciou principalmente os genes relacionados à maturação nuclear (19\%), comunicação entre células do CCOs (14\%), expansão do cumulus (14\%) e embriogênese (14\%). Os genes associados às demais funções (fertilização, maturação citoplasmática, viabilidade oocitária, esteroidogênese, reparo e integridade do DNA, epigenética e corpo lúteo) também foram influenciados, porém em menor número (Figura 18). 
A

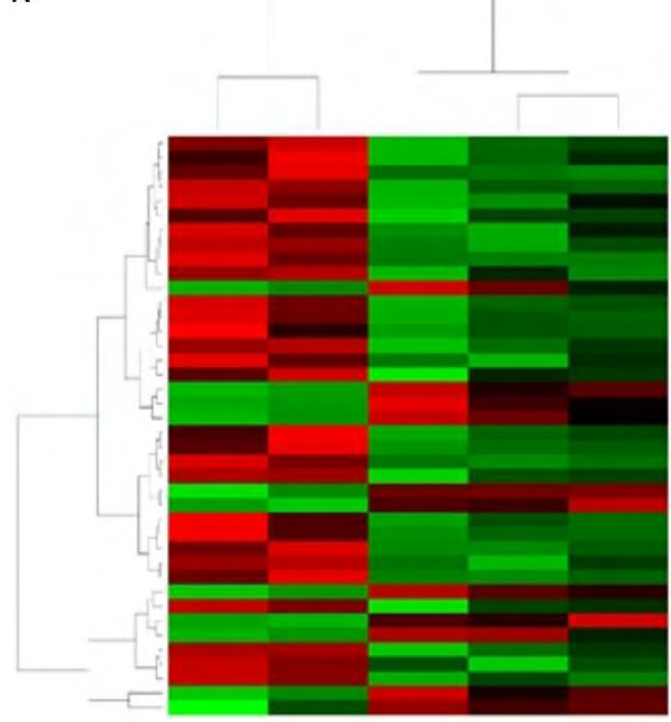

B

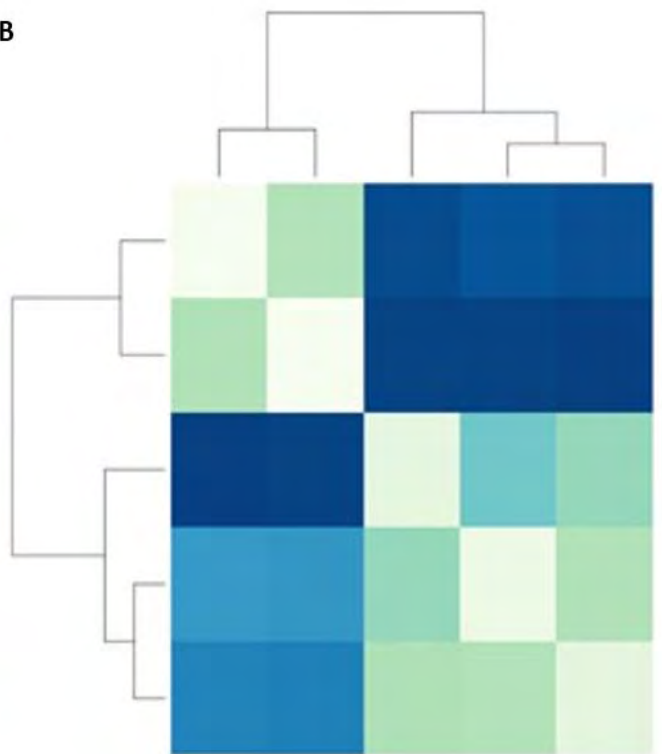

Figura 17. A) Heat-map, (B) Heatmap-distance do perfil de transcriptomas de células do cumulus oriundas de CCOs suínos maturadas in vitro em meio acrescido ou não de melatonina, determinados por RNA-Seq.

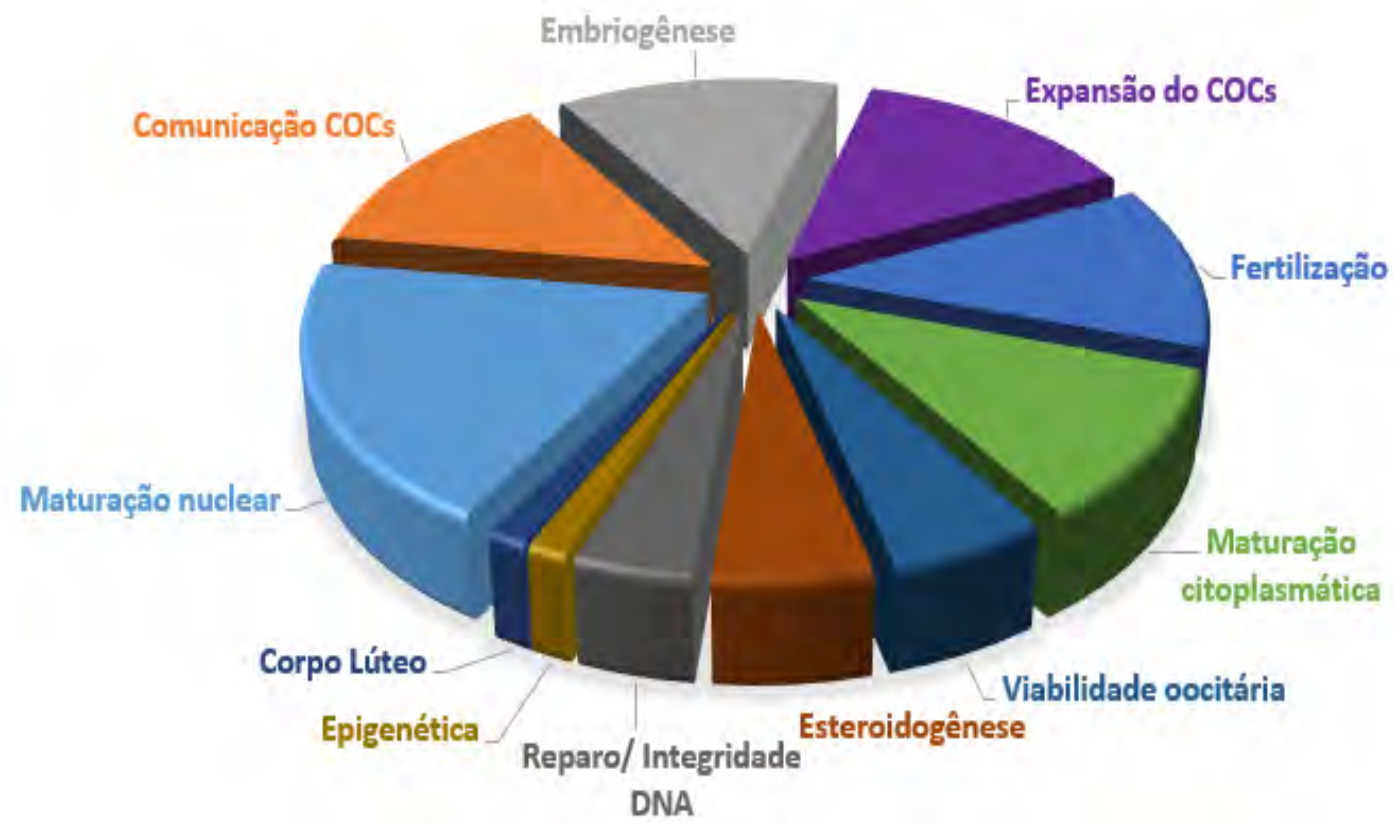

Figura 18. Perfil de transcriptomas de células do cumulus, oriundas de CCOs suínos maturadas in vitro em meio acrescido de melatonina, com as funções biológicas associadas à viabilidade oocitária e desenvolvimento embrionário.

A partir da análise do perfil de transcriptomas relacionados à viabilidade oocitária e desenvolvimento embrionário, verificou-se que a adição da 
melatonina resultou em aumento na expressão de 68 genes associados a 11 funções biológicas: comunicação entre células do CCOs, expansão do cumulus, maturação nuclear, maturação citoplasmática, viabilidade oocitária, reparo e integridade do DNA, epigenética, esteroidogênese, fertilização, corpo lúteo e embriogênese. Os genes associados à maturação oócitária, fertilização e embriogênese foram os mais afetados (Tabela 10).

Tabela 10. Genes associados à viabilidade oocitária e desenvolvimento embrionário que tiveram a expressão aumentada com a suplementação da melatonina ao meio de maturação em células do cumulus oriundas de CCOs suínos maturadas in vitro.

\begin{tabular}{|c|c|c|}
\hline FUNÇÃO & $\begin{array}{l}N^{\circ} \text { DE } \\
\text { GENES }\end{array}$ & SÍMBOLO DO GENEa \\
\hline Maturação nuclear & 11 & $\begin{array}{c}\text { FBLIM1, EPHB4, FHL2, CCNG2, KIF13B, } \\
\text { WEE1, ACVR1, CLK1, OSGIN2, RAB39B, } \\
\text { BTG2 }\end{array}$ \\
\hline Comunicação CCOs & 10 & $\begin{array}{l}\text { FBLIM1, ZNF606, NCAM1, DSP, FNBP1L, } \\
\text { TES, DSG2, BTG2, SLC38A1, SLC6A15 }\end{array}$ \\
\hline Embriogênese & 10 & $\begin{array}{l}\text { LAMB1, KLF4, NCAM1, GATA-3, JAG1, } \\
\text { RSPO2, TRIM24, TANC2, RAB39B, PCSK6 }\end{array}$ \\
\hline Expansão do CCOs & 9 & $\begin{array}{l}\text { GNPTAB, PFKFB3, KLHL24, ENO2, } \\
\text { PFKFB4, IL10RA, TLR3, PEAK1, TBX2 }\end{array}$ \\
\hline Fertilização & 9 & $\begin{array}{c}\text { FBLIM1, ZNF606, NCAM1, DSP, FNBP1L, } \\
\text { TES, DSG2, BTG2, RND1 }\end{array}$ \\
\hline $\begin{array}{c}\text { Maturação } \\
\text { citoplasmática }\end{array}$ & 7 & $\begin{array}{l}\text { RND1, FNBP1L, TES, FRMD4A, TUBB3, } \\
\text { KIF13B, MYO1B }\end{array}$ \\
\hline Viabilidade oocitária & 4 & FHL2, HES1, BTG2, BTBD11 \\
\hline $\begin{array}{c}\text { Reparo/ Integridade } \\
\text { DNA }\end{array}$ & 3 & SOX4, APLF, FAM171B \\
\hline Esteroidogênese & 3 & RASSF8, PRKG2, ABCA1 \\
\hline Corpo Lúteo & 1 & MXI1 \\
\hline Epigenética & 1 & RCOR2 \\
\hline
\end{tabular}

Por outro lado, a suplementação do meio de maturação com melatonina inibiu a expressão de oito genes associados a quatro processos biológicos: expansão do cumulus, maturação nuclear, maturação citoplasmática e esteroidogênese (Tabela 11). A melatonina inibiu a expressão principalmente de genes relacionados à maturação nuclear. Quando comparado o número de 
genes cuja expressão aumentou versus aqueles que tiveram a expressão reduzida, é possível verificar que a melatonina não reduziu a expressão de nenhum gene associado à viabilidade celular, comunicação entre células do CCOs, integridade e reparo do DNA, fertilização ou embriogênese (Figura 19).

Tabela 11. Genes associados à viabilidade oocitária e desenvolvimento embrionário que tiveram a expressão reduzida com a suplementação da melatonina ao meio de maturação em células do cumulus oriundas de CCOs suínos maturadas in vitro.

\begin{tabular}{|ccc|}
\hline FUNÇÃO & NN DE GENES & SíMBOLO DO GENEa \\
\hline $\begin{array}{c}\text { Maturação nuclear } \\
\text { Maturação } \\
\text { citopasImática }\end{array}$ & 4 & MOK, PENK, NCKAP1L, CRELD2 \\
\hline Expansão do coCs & 2 & TUBA1B, MAP1A \\
\hline Esteroidogenese & 1 & UGDH \\
\hline aŚmbolo do gene ortólogo humano. & 1 & StAR \\
\hline
\end{tabular}

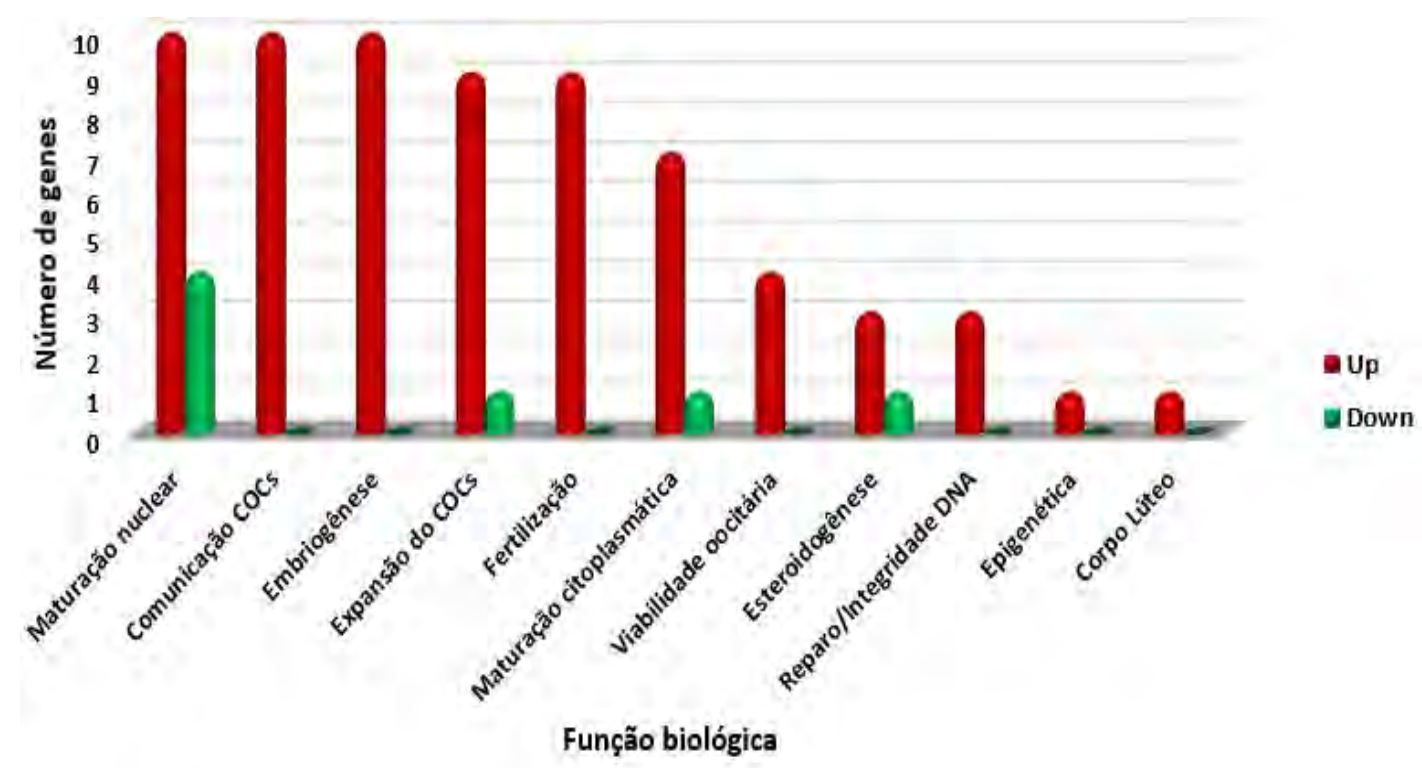

Figura 19. Quantidade de genes com expressão aumentada (vermelho) ou reduzida (verde) pela melatonina, verificada por meio do perfil de transcriptomas de células do cumulus oriundas de CCOs suínos maturadas in vitro

Em relação à maturação oocitária, a suplementação do meio de maturação com melatonina influenciou a expressão de genes associados à maturação nuclear por meio do aumento (i.e., FHL2, EPHB4, CCNG2, RAB39B, FBLIM1, KIF13B, ACVR1 e WEE1) e redução (MOK, PENK, NCKAP1L e 
CRELD2). Do mesmo modo, a melatonina influenciou genes relacionados à maturação citoplasmática aumentando (i.e., RND1, TUBB3, KIF13B e MYO1B) e reduzindo (TUBA1B e MAP1A) a expressão de gênica. Em adição, a presença da melatonina aumentou na expressão de genes associados ao reparo do DNA e RNA, interação proteína/proteína e proteína/DNA (SOX4, APLF e FAM171B), bem como de mecanismos epigenéticos (RCOR2).

A suplmentaçao com melatonina aumentou a expressão de genes associados à esteroidogênese como RASSF8, PRKG2 e ABCA1 reduziu a expressão do gene que codifica a proteína reguladora esteroidogênica aguda (StAR), responsável pelo transporte de colesterol pela a membrana interna da mitocôndria. Do mesmo modo, a melatonina influenciou genes envolvidos na expansão do cumulus e sua comunicação intercelular por meio dos genes associados à produção de ácido hialurônico (expansão; TBX2, GNPTAB, PEAK1 e TLR3) e transporte e adesão celular (comunicação intercelular; FBLIM1, NCAM1, DSP, DSG2 e BTG2).

Além disso, as células do cumulus maturadas em meio contento melatonina, mostraram um aumento na expressão de genes associados à embriogênese pré- e pós-implantacional, placentação e organogênese (LAMB1, KLF4, NCAM1, GATA-3, JAG1, RSPO2, TRIM24, TANC2, RAB39B, PCSK6).

\subsection{DISCUSSÃO}

A melatonina tem sido descrita em diferentes estudos, e em diferentes espécies, como benéfica na suplementação do meio de maturação de in vitro (RODRIGUEZ- OSORIO et al., 2007; CHOI et al., 2008; KANG et al., 2009; SHI et al., 2009; MANJUNATHA et al., 2009; CASÃO et al., 2010; EL-RAEY et al., 2011). No entanto, nosso estudo é o primeiro a fazer uma abordagem mais ampla da ação da melatonina sobre a expressão gênica de células do cumulus.

O sequenciamento do trascriptoma das células do cumulus gerou uma biblioteca de genes regulados pela melatonina durante a MIV, contribuindo assim com novas informações sobre como que essa indolamina poderia agir indiretamente sobre a maturação e viabilidade oocitária, por meio de ações sobre as células do cumulus. Nosso estudo corrobora os relatos de que a 
suplementação do meio de maturação com melatonina estimula a maturação nuclear (CHOI et al., 2008; KANG et al., 2009; SHI et al., 2009). No presente estudo observou-se que a melatonina estimulou nas células do cumulus a expressão de 18 genes associados à maturação oocitária.

Notoriamente, as células do cumulus são fundamentais para a aquisição da competência oócitária (ZHOU et al., 2016). É sabido que as células do cumulus têm a habilidade de transferir pequenos metabólitos (VAN SOOM et al., 2002), fatores parácrinos (HUSSEIN et al., 2006) e até mesmo RNAm (MACAULAY et al., 2014) para o oócito. Nossos resultados corroboram com Su et al. (2002), que sugerem a habilidade das células do cumulus em influenciar o ciclo celular do oócito. Com base nisso, podemos inferir que a adição melatonina aumenta a expressão de genes associados à maturação nuclear nas células do cumulus, o que pode vir a influenciar na progressão meiótica do oócito.

Conforme descrito no capítulo anterior, os genes FHL2, EPHB4, CCNG2, RAB39B, FBLIM1 e KIF13B, são fundamentais para a proliferação celular (LABALETTE et al., 2008; MILLER et al., 1998). O aumento na expressão desses genes é essencial para a expansão do cumulus e possivelmente para a retomada meiótica em oócitos, uma vez que os genes FHL2 e EPHB4 estimulam a divisão celular e os genes RAB39B, FBLIM1 e KIF13B são responsáveis pela formação do fuso mitótico, da carioteca e da movimentação dos centríolos (TORRES et al., 2011). Embora os genes CLK1 e OSGIN2 sejam classificados como reguladores do ciclo celular (RODRIGUEZ et al., 2009; CARLETTI; CHRISTENSON, 2009), o mecanismo de ação bem como a importância no processo reprodutivo ainda permanece desconhecido.

Outra forma pela qual a melatonina estimularia a progressão meiótica de oócitos, seria pelo aumento da expressão de receptores de ativina nas células do cumulus. De acordo com Sidis et al. (1998), as células do cumulus são a fonte primária de ativina para o oócito, uma vez que oócitos não sintetizam ou secretam ativina. Nosso estudo mostrou, pela primeira vez, que a melatonina aumentou a expressão do receptor de ativina tipo 1 (ACVR1). A ativina tem um papel autócrino/parácrino no ambiente intraovariano, capaz de modular simultaneamente a esteroidogênese e dinâmica folicular ovariana (LUISI et al., 2003). De acordo com Alan et al. (1998) e Silva e Knight (1998), a ativina 
estimula a maturação nuclear em oócitos maturados in vitro, na espécie murina e bovina, respectivamente.

A melatonina estimulou os genes BTG2 e WEE1 que impedem a transição da fase G1/S e G2/M, respectivamente (LI et al., 2009; SOLC et al., 2010) e são essenciais para o ciclo celular. De acordo com Li et al. (2009), o aumento na expressão dos genes da família BTG2 resulta em uma resposta antiapoptótica por meio da interrupção do ciclo celular. Conforme descrito no capítulo anterior, a taxa de apoptose em células de cumulus pode ser utilizada como indicador da qualidade oocitária (ALISCH et al., 2003). Deste modo a suplementação do meio de maturação com melatonina poderia resultar em maior número de células do cumulus saudáveis, bem como em maior qualidade oocitária.

Além disso, a melatonina estimulou a expressão do gene BTBD11, gene responsivo ao ácido retinóico (RA) (MOHAN et al., 2003). Embora os RAs sejam essenciais para a esteroidogênese ovariana, maturação oocitária e embriogênese inicial (MEMILI et al., 2007), ainda não se sabe o mecanismo exato pelo qual o BTBD11 age no sistema reprodutivo.

Previamente, Kang et al. (2009) e El-Raey et al. (2011) relataram a influência positiva da suplementação do meio de maturação com melatonina sobre a maturação citoplasmática, e sugeriram que a melatonina influenciaria na atividade metabólica e reorganização mitocondrial de oócitos. Nossos achados mostraram que a melatonina estimula a expressão de genes associados à organização do citoesqueleto (RND1, FNBP1L, TES, FRMD4A) e dinâmica dos microtúbulos (TUBB3, KIF13B, MYO1B), ao mesmo tempo em que reduz a expressão dos genes TUBA1B e MAP1A, ambos associados à dinâmica de microtúbulos. Além disso, a melatonina reduz a expressão dos genes MOK, PENK, NCKAP1L e CRELD2 associados à maturação nuclear. Deste modo, os nossos resultados sugerem que a melatonina regula o ciclo celular das células do cumulus, e provavelmente a maturação oocitária por meio de mecanismos antagônicos.

Sliwinski et al. (2007) sugeriram que a melatonina seria capaz de reparar o DNA danificado. Nossos resultados sugerem que a melatonina repara danos no DNA e RNA, por meio do aumento na expressão do gene Apraxin (APLF). De acordo com Tumbale et al. (2014), o APLF codifica a enzima apraxin 
deadenilase que repara DNA e RNA adenilado, mantendo a integridade do genoma e consequentemente a sobrevivência celular. Além disso, nosso estudo mostrou que a melatonina aumenta na expressão do gene SOX4, o que possivelmente estimula a transativação do DNA, fundamental na embriogênese inicial. O SOX4, assim como outros membros da família SOX, tem como habilidade promover a transativação, facilitando assim a interação proteína/proteína e proteína/DNA (HUNT; CLARKE, 1999), essencial para a comunicação com o aparato de tradução ou síntese de proteínas.

Nosso estudo é o primeiro a relatar que a suplementação com melatonina aumenta a expressão do gene RCOR2 (REST corepressors 2), cuja função está associada a mecanismos de ação epigenéticos. Nossos resultados corroboram com os estudos de Korkmaz e Reiter (2008) e Korkmaz et al. (2012), que sugeriram que a melatonina desencadearia um de sistema de herança epigenética, através de mudanças na superestrutura do DNA. O gene RCOR2 pertence à família CoREST (BALLAS; MANDEL 2005; MCGRAW et al., 2007), e possui a habilidade de formar imunocomplexos com as enzimas modificadoras de histonas HDAC1, HDAC2 (HUMPHREY et al., 2001, YOU et al., 2001), EHMT2 e LSD1 (SHI et al., 2003; 2004). As funções de REST e CoREST incluem a metilação e demetilação de histonas, reposicionamento do nucleossomo e remodelamento global da cromatina, por meio da modulação do sinal de diversas vias, fatores de transcrição e epigenéticos (LUNYAK et al., 2002; ABRAJANO et al., 2009). Sendo assim, a melatonina pode ser responsável por modificações epigenéticas em células do cumulus e oócitos, uma vez que Macaulay et al. (2014) descreveram o transporte de RNAm por meio das junções comunicantes.

Nossos dados revelam que a suplementação com melatonina aumenta a expressão de genes associados à síntese de ácido hialurônico (TBX2 e GNPTAB). De acordo com Jiang et al. (2011), o gene TBX2 induz a expressão de HAS2 e TGF 3 . O gene GNPTAB, por sua vez, codifica a enzima de membrana N-acetylglucosamine-1-phosphotransferase (GlcNAc1P), um precursor da via bioquímica intracelular do ácido hialurônico (WEIGEL; DEANGELIS, 2007). Curiosamente, a melatonina reduz a expressão do gene UGDH, cuja função principal está associada à produção de ácido hialurônico, o que certamente está associado à manutenção da homeostase e viabilidade 
celular. A expansão do cumulus envolve uma grande reestruturação do citoesqueleto através do microfilamentos de actina além da indução da síntese de ácido hialurônico (HA) da matriz extracleular (NAGYOVA, 2012).

Além disso, a melatonina possivelmente promove a expansão do cumulus por via aumento na expressão dos genes PEAK1 e TLR3. De acordo com An et al. (2014), o gene Pseudopodium-enriched atypical kinase 1 (PEAK1), regula a movimentação dos microfilamentos de actina e combinado aos genes Fyn, Akt e as GTPases Rho, induz a fosforilação da tirosina e desencadeia a polimerização da actina. Em células do cumulus, microfilamentos de actina desencadeiam uma sequência de eventos que resultam na a expansão do cumulus, por meio de modificações no citoesqueleto e do aumento da síntese da matriz extracelular (ŠUTOVSKÝ et al., 1993; 1995). Além disso, o gene TLR3, que também teve sua expressão aumentada pela melatonina, foi associado à expansão do cumulus, na migração dos CCOs pelo oviduto e na fertilização subsequente, em estudos utilizando CCOs de camundongos (LIU et al., 2009).

Embora estudos em outros tipos celulares mostrem a propriedade antiinflamatória da melatonina relacionada ao aumento da expressão das interleucinas 1 e 10 (IL-1 e IL-10) (PICINATO et al., 2008; JAWOREK et al., 2012), nosso estudo é o pioneiro em identificar o aumento na expressão do receptor da IL-10 em células do cumulus. Recentemente King (2013), comprovaram que a IL-10 regula a produção de ácido hialurônico em fetos humanos. Deste modo, podemos inferir que o aumento de receptores de IL-10 nas células do cumulus, promovido pela melatonina, poderia prover mais um mecanismo para facilitar a expansão do cumulus.

A suplementação do meio de maturação com melatonina resultou em aumento da expressão do gene ABCA1. A proteína transportadora de superfície codificada pelo gene ABCA1 (ATP-binding cassette transporter A1) é essencial para a esteroidogênese por meio do efluxo de colesterol celular (WANG et al, 2000; REMALEY et al, 2001; BRUNHAM et al, 2006; DROUINEAUD et al., 2007). As células do cumulus são responsáveis pela síntese e transferência do colesterol para o oócito via transportadores de membrana ABCA1, ABCG1, ABCG4 (SU et al., 2008). Os oócitos não têm a habilidade de acumular colesterol no ambiente intracelular, não possuem 
receptores ou a capacidade de sintetizar colesterol de novo, então deste modo, o colesterol utilizado na biossíntese de esteroides tem como principal origem a absorção seletiva pelas células do cumulus (SU et al., 2008; FUJIMOTO et al., 2010).

Em nosso estudo, verificamos que a melatonina pode influenciar a esteroidogênese por meio do aumento na expressão do gene PRKG2. O gene PRKG2 codifica a proteína cinase dependente de GMPc II. De acordo com Sriraman et al. (2006), o PRKG2 é induzido seletivamente por mecanismos dependentes de $\mathrm{LH} / \mathrm{hCG}$ e progesterona em células da granulosa e do cumulus no processo de ovulação. PRKG2 estimula a expansão do cumulus, diferenciação das células da granulosa, bem como o bloqueio da síntese de AMPc, de aromatase e inibina e os receptores de LH.

Para que a síntese de esteroides ocorra é necessária uma combinação de diversos fatores, entre eles a síntese de novas proteínas e a fosforilação proteica. O gene PRKG2 tem como função a fosforilação da proteína StAR, embora não haja aumento na expressão da mesma (GAMBARYAN et al., 2003). No presente estudo, a suplementação com melatonina reduziu a expressão do gene StAR. Wu et al. (2001) mostraram que a melatonina em diferentes concentrações suprime a expressão da proteína StAR em células de Leydig em ratos. A redução da proteína StAR age possivelmente como um controle negativo sobre a super-expressão de outros genes que estimulam a síntese de esteroides.

No presente trabalho a melatonina estimulou oito genes associados à adesão celular (FBLIM1, ZNF606, NCAM1, DSP, FNBP1L, TES, DSG2 e BTG2), dois genes associados ao transporte intra/extracelular (SLC6A15 e SLC38A1), o que provavelmente justifica a sua habilidade em melhorar a viabilidade celular e a fertilização. De acordo com Talbot et al. (2003), a adesão celular é crucial para comunicação entre as células epiteliais do oviduto e a matriz extracelular do CCO, e finalmente para a adesão e fusão entre o oócito e o espermatozoide no momento da fecundação.

A melatonina aumentou a expressão do gene RND1, que atua como gatilho molecular desencadeando uma ampla variedade de processos celulares fundamentais para células somáticas, incluindo a organização do citoesqueleto e a progressão do ciclo celular, sobrevivência, polaridade e migração celular. 
Em estudos feitos com animais knockout, o desligamento desse gene resulta em defeitos de expansão cumulus, falha na extrusão do corpúsculo polar e na clivagem embrionária subsequente (ZHANG et al., 2014). Deste modo, podemos inferir que a adição melatonina pode influenciar, por meio do gene RND1, no processo de fertilização e desenvolvimento embrionário. Além disso, a suplementação com melatonina resultou em aumento na expressão dos genes LAMB1, KLF4, NCAM1 e GATA-3, os quais são associados à diferenciação de células tronco mesenquimais.

Com base nos dados encontrados de que a suplementação com melatonina está relacionada com a competência e viabilidade embrionária (Figura 18), comparamos a lista de genes regulados pela melatonina durante a MIV com genes previamente considerados como marcadores de qualidade embrionária. A partir dessa análise, observamos que muitos dos genes regulados neste processo estão de fato relacionados tanto com a qualidade do oócito como com o potencial desenvolvimento embrionário subsequente. Assim, esta biblioteca de genes poderá ser utilizada para identificar novos marcadores nas células do cumulus que são relacionadas com a viabilidade do oócito e embrião, ampliando os conhecimentos a respeito dos mecanismos pelos quais a melatonina age desde a maturação oocitária até a formação e desenvolvimento do embrião. 


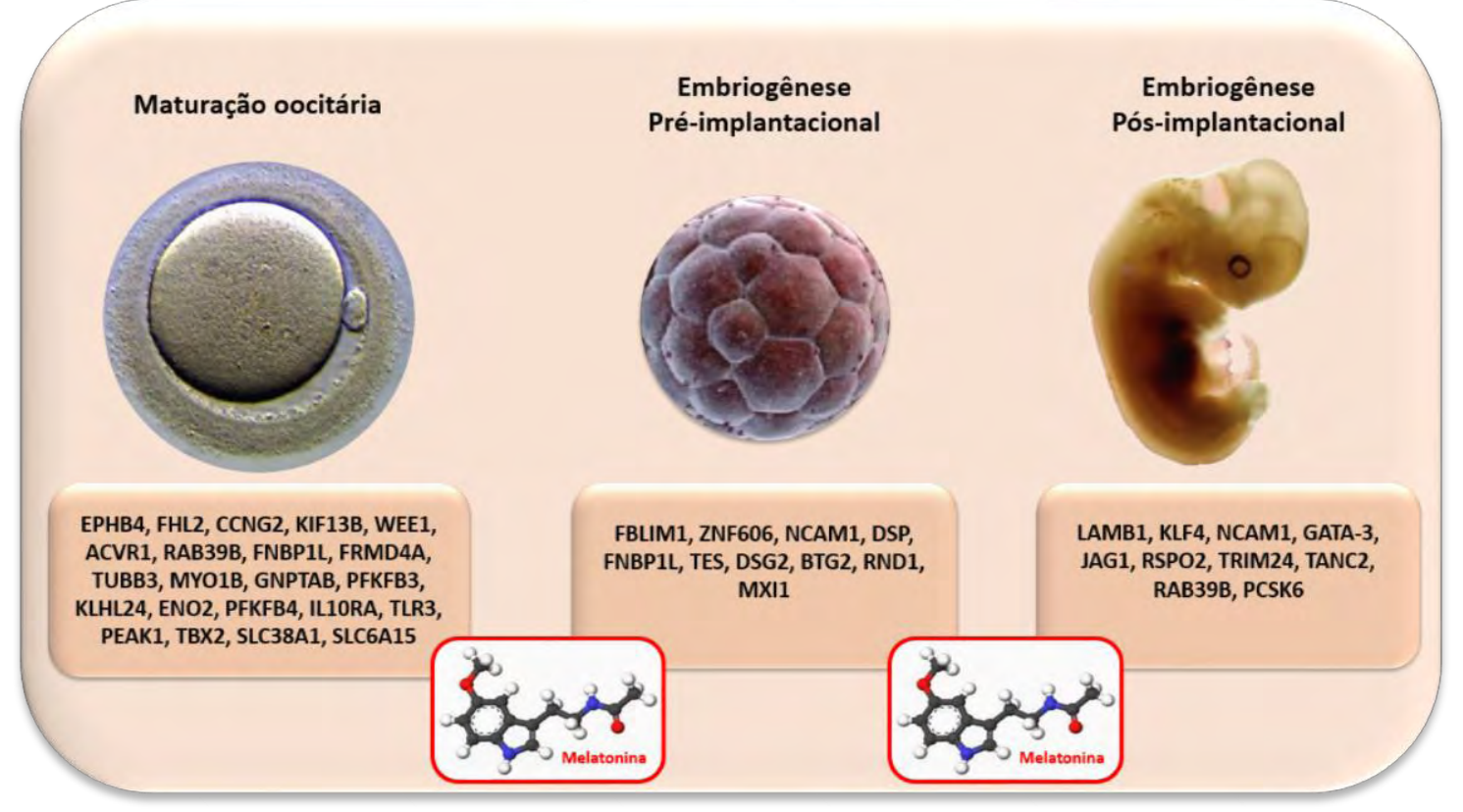

Figura 20. Mecanismos de ação indireta da melatonina sobre a expressão de genes nas células do cumulus associados à maturação oocitária e embriogênese.

A partir dos resultados encontrados no presente estudo, pode-se concluir que a melatonina influencia a expressão de genes nas células do cumulus suínas que são relacionadas à maturação nuclear, maturação citoplasmática, expansão do cumulus e viabilidade oocitária via regulação da expressão de genes essenciais para a oogênese e foliculogênese. A suplementação do meio de maturação com melatonina resulta em aumento do transcriptoma de um número expressivo de genes associados à aquisição da competência oócitária bem como da viabilidade embrionária e desenvolvimento subsequente.

\section{REFERENCIAS}

ADRIAENS, I., JACQUET, P., CORTVRINDT, R., JANSSEN, K., SMITZ, J. Melatonin has dose-dependent effects on folliculogenesis, oocyte maturation capacity and steroidogenesis. Toxicology, v. 228, p. 333-343, 2006.

AIELLO RJ, BREES D, FRANCONE OL. ABCA1-deficient mice: insights into the role of monocyte lipid efflux in HDL formation and inflammation. Arteriosclerosis, Thrombosis, and Vascular Biology, v.23, p. 972-980, 2003. 
ABRAJANO JJ, QURESHI IA, GOKHAN S, ZHENG D, BERGMAN A, MEHLER MF. REST and CoREST modulate neuronal subtype specification, maturation and maintenance. PLoS One, v 4, p. 7936, 2009.

ALAK BM, COSKUN S, FRIEDMAN CI, KENNARD EA, KIM MH, SEIFER DB: Activin A stimulates meiotic maturation of human oocytes and modulates granulosa cell steroidogenesis in vitro. Fertility and Sterility, v. 70, p. 11261130, 1998.

AN L, LIU S, ZHANG W, ZHANG Y, HUANG Y, HU X, CHEN S, ZHAO S. Mouse Fyn induces pseudopodium formation in Chinese hamster ovary cells. Journal of Veterinary Science, .v. 15, n. 1, p. 111-115, 2014.

BAI Q, ASSOU S, HAOUZI D, RAMIREZ JM, MONZO C, BECKER F, GERBAL-CHALOIN S, HAMAMAH S, DE VOS J. Dissecting the first transcriptional divergence during human embryonic development. Stem Cell Reviews and Reports, v. 8, n. 1, p. 150-162, 2012.

BALLAS N, MANDEL $G$. The many faces of REST oversee epigenetic programming of neuronal genes. Current Opinion in Neurobiology, v. 15, n. 5, p. 500-506, 2005.

BANERJEE, J., MAITRA, D., DIAMOND, M.P., ABU-SOUD, H.M. Melatonin prevents hypochlorous acid-induced alterations in microtubule and chromosomal structure in metaphase-II mouse oocytes. Journal of Pineal Research, v. 53, p. 122-128, 2012.

BARCHAS J, DACOSTA F, SPECTOR S. Acute pharmacology of melatonin. Nature. 1967;214:919-20. Wurtman RJ, Axelrod J, Potter LT. The uptake of $\mathrm{H} 3-$ melatonin in endocrine and nervous tissues and the effects of constant light exposure. Journal of Pharmacology and Experimental Therapeutics, v. 143: 314-318, 1964.

BRANNIAN JD, FURMAN GM, DIGGINS M. Declining fertility in the lethal yellow mouse is related to progressive hyperleptinemia and leptin resistance. Reproduction Nutrition Development.v. 45, n. 2, p. 143-150, 2005.

BRUNHAM L, KRUIT J, IQBAL J, FIEVET C, TIMMINS J, PAPE T, COBURN B, BISSADA N, STAELS B, GROEN A. Intestinal ABCA1 directly contributes to HDL biogenesis in vivo. Journal of Clinical Investigation, v. 116, p. 10521062, 2006.

CAO Q, ZHANG X, LU L, YANG L, GAO J, GAO Y, MA H, CAO Y. Klf4 is required for germ-layer differentiation and body axis patterning during Xenopus embryogenesis. Development, v. 139, p. 3950-3961, 2012

CARLETTI M, CHRISTENSON L. Rapid effects of LH on gene expression in the mural granulosa cells of mouse periovulatory follicles. Reproduction, $v$. 137, p. 843-855, 2009. 
CASAO, A., ABECIA, J.A., CEBRIAN PEREZ, J.A., MUIÑO-BLANCO, T., VÁZQUEZ, M.I., FORCADA, F. The effects of melatonin on in vitro oocyte competence and embryo development in sheep. Spanish Journal of Agricultural Research, v. 8, p. 35-41, 2010.

CHAFFIN CL, BROGAN RS, STOUFFER RL, VANDEVOORT CA. Dynamics of Myc/Max/Mad expression during luteinization of primate granulosa cells in vitro: association with periovulatory proliferation. Endocrinology, v. 144, n. 4, p. 1249-1256, 2003.

CHENG Y, KAWAMURA K, TAKAE S, DEGUCHI M, YANG Q, KUO C, HSUEH AJ. Oocyte-derived R-spondin2 promotes ovarian follicle development. FASEB Journal. v. 27, n 6, p. 2175-2184, 2013.

CHOI, J., PARK, S.M., LEE, M., KIM, J.H., JEONG, Y.I., LEE, J.Y., PARK, S.W., KIM, H.S., HOSSEIN, M.S., JEONG, Y.W., KIM, S., HYUN, S.H., HWANG, W.S. Anti-apoptotic effect of melatonin on porcine parthenogenic embryos. Molecular Human Reproduction, v. 75, p. 1127-1135, 2008.

CHRISTIANSEN-WEBER TA, VOLAND JR, WU Y, NGO K, ROLAND BL, NGUYEN S, PETERSON PA, FUNG-LEUNG W-P. Functional loss of ABCA1 in mice causes severe placental malformation, aberrant lipid distribution, and kidney glomerulonephritis as well as high-density lipoprotein cholesterol deficiency. American Journal of Pathology, v. 157, p. 1017-1029, 2000.

CIPOLLA-NETO J, AMARAL FG, AFECHE SC, TAN DX, REITER RJ. Melatonin, energy metabolism, and obesity: a review. Journal of Pineal Research, v. 56, n. 4, p. 371-381, 2014.

COMISKEY M, WARNER CM. Spatio-temporal localization of membrane lipid rafts in mouse oocytes and cleaving preimplantation embryos. Developmental Biology, v. 303, p 727-739, 2007.

CONSTAM DB, ROBERTSON E J. SPC4/PACE4 regulates a TGFbeta signaling network during axis formation. Genes \& Development, v. 14, p. 1146-1155, 2000.

DIAS F, SUGIURA K, EPPIG J. Regulation of Pcsk6 expression during the preantral to antral follicle transition in mice: opposing roles of $\mathrm{FSH}$ and oocytes. Biology of Reproduction, v. 78, n. 1, p. 176-183, 2008.

DROUINEAUD V, SAGOT P, GARRIDO C, LOGETTE E, DECKERT V, GAMBERT P, JIMENEZ C, STAELS B, LAGROST L, MASSON D. Inhibition of progesterone production in human luteinized granulosa cells treated with LXR agonists. Molecular Human Reproduction, v. 13, p. 373-379, 2007.

EL-RAEY, M., GESHI, M., SOMFAI, T., KANEDA, M., HIRAKO, M., ABDELGHAFFAR, A.E., SOSA, G.A., ABAU EL-ROOS, M.E.A., NAGAl, T. Evidence of melatonin synthesis in the cumulus oocyte complexes and its role in 
enhancing oocyte maturation in vitroin cattle. Molecular Reproduction and Development, v.78, p. 250-262, 2011.

FUJIMOTO VY, KANE JP, ISHIDA BY, BLOOM MS, BROWNE RW. Highdensity lipoprotein metabolism and the human embryo. Human Reproduction Update, v. 6, n. 1, p. 20-38, 2010.

GAMBARYAN S, BUTT E, MARCUS K, GLAZOVA M, PALMETSHOFER A, GUILLON G, SMOLENSKI A. cGMP-dependent protein kinase type II regulates basal level of aldosterone production by zona glomerulosa cells without increasing expression of the steroidogenic acute regulatory protein gene. The Journal of Biological Chemistry, v. 278, n. 32, p. 29640-29648, 2003.

GIANNANDREA M, BIANCHI V, MIGNOGNA ML, SIRRI A, CARRABINO S, D'ELIA E, VECELLIO M, RUSSO S, COGLIATI F, LARIZZA L, ROPERS HH, TZSCHACH A, KALSCHEUER V, OEHL-JASCHKOWITZ B, SKINNER C, SCHWARTZ CE, GECZ J, VAN ESCH H, RAYNAUD M, CHELLY J, DE BROUWER AP, TONIOLO D, D'ADAMO P. Mutations in the small GTPase gene $\mathrm{RAB39B}$ are responsible for $\mathrm{X}$-linked mental retardation associated with autism, epilepsy, and macrocephaly. The American Journal of Human Genetics, v. 86, n. 2, p. 185-195, 2010.

HAN W, CHEN S, YU KN, WU L. Nitric oxide mediated DNA double strand breaks induced in proliferating bystander cells after alpha-particle irradiation. Mutation Research, v. 684, p. 81-89, 2010.

HANAHAN, D. (1997) Signaling vascular morphogenesis and maintenance. Science, $277,48-50$.

HUMPHREY GW, WANG Y, RUSSANOVA VR, HIRAI T, QIN J, NAKATANI $Y$, HOWARD BH: Stable histone deacetylase complexes distinguished by the presence of SANT domain proteins CoREST/kiaa0071 andMta-L1. The Journal of Biological Chemistry, v. 276, p. 6817-6824, 2001.

HUNT S, CLARKE B. Expression and hormonal regulation of the Sox4 gene in mouse female reproductive tissues. Biology of Reproduction 61, 476-481 1999

IRMAK MK, TOPAL T, OTER S. Melatonin seems to be a mediator that transfers the environmental stimuli to oocytes for inheritance of adaptive changes through epigenetic inheritance system. Medical Hypotheses, p. 1138-1140, 2005.

JAWOREK J, SZKLARCZYK J, JAWOREK AK, NAWROT-PORĄBKA K, LEJA-SZPAK A, BONIOR J, KOT M. Protective effect of melatonin on acute pancreatitis. International Journal of Inflammation, v. 2012:173675, 2012.

JIANG D, LIANG J, NOBLE PW. Hyaluronan as an immune regulator in human diseases. Physiological Reviews, 91, n. 1, p. 221-264, 2011. 
KANG, J.T., KOO, O.J., KWON, D.K., PARK, H.J., JANG, G., KONG, S.K., LEE, B.C. Effects of melatonin on in vitro maturation of porcine oocyte and expression of melatonin receptor RNA in cumulus and granulosa cells. Journal of Pineal Research, v. 46, p. 22-28, 2009.

KING A, BALAJI S, LE LD, MARSH E, CROMBLEHOLME TM, KESWANI SG. Interleukin-10 regulates fetal extracellular matrix hyaluronan production. Journal of Pediatric Surgery, v. 48, n. 6, p. 1211-1217, 2013.

KLEMENTIEV B, BICHEVAJA N, NOVIKOVA T, CHEBOTAR N, BOCK E AND BEREZIN V. A peptide agonist of the neural cell adhesion molecule (NCAM), C3, protects against developmental defects induced by a teratogen pyrimethamine. International Journal of Developmental Neuroscience, v. 20, p. 527-536, 2002.

KORKMAZ A, REITER RJ. Epigenetic regulation: a new research area for melatonin? Journal of Pineal Research, v. 44, n. 1, p. 41-44, 2008.

KORKMAZ, A., ROSALES-CORRAL, S., REITER, R.J. Gene regulation by melatonin linked to epigenetic phenomena. Gene, v.503, p. 1-11, 2012.

LABALETTE C, NOUËT Y, SOBCZAK-THEPOT J, ARMENGOL C, LEVILLAYER F, GENDRON MC, RENARD CA, REGNAULT B, CHEN J, BUENDIA MA, WEI Y. The LIM-only protein FHL2 regulates cyclin D1 expression and cell proliferation. The Journal of Biological Chemistry, 30;283(22) 2008.

LI F, LIU J, PARK ES, JO M, CURRY TE JR. The B cell translocation gene (BTG) family in the rat ovary: hormonal induction, regulation, and impact on cell cycle kinetics. Endocrinology, v. 150, n. 8, p. 3894-902, 2009.

LIU Z, DE MATOS DG, FAN HY, SHIMADA M, PALMER S, RICHARDS JS. Interleukin-6: an autocrine regulator of the mouse cumulus cell-oocyte complex expansion process. Endocrinology, v. 150, n. 7, p 3360-3368, 2009.

LONERGAN, P.; MONAGHAN, P.; RIZOS, D.Effect of follicle size on bovine oocyte quality and development competence following maturation, fertilization and culturein vitro.Molecule Reproduction Development, v. 37, p. 48 -53, 1994.

LU DP, TIAN L, O'NEILL C, KING NJ. Regulation of cellular adhesion molecule expression in murine oocytes, peri-implantation and post-implantation embryos. Cell Research, v. 12, p. 373-383, 2002.

LUCHETTI F, CANONICO B, BARTOLINI D, ARCANGELETTI M, CIFFOLILLI S, MURDOLO G, PIRODDI M, PAPA S, REITER RJ, GALLI F. Melatonin regulates mesenchymal stem cell differentiation: a review. Journal of Pineal Research, v. 56, n 4, p. 382-397, 2014.

LUISI S, PALUMBO M, CALONACI G, DE LEO V, RAZZI S, INAUDI P, COBELLIS G, PETRAGLIA F. Serum inhibin B correlates with successful 
ovulation in infertile women. Journal of Assisted Reproduction and Genetics, v. 20, n. 6, p. 241-247, 2003.

LUNYAK VV, BURGESS R, PREFONTAINE GG, NELSON C, SZE SH, CHENOWETH J. Corepressor-dependent silencing of chromosomal regions encoding neuronal genes. Science, v. 298, p. 1747-1752, 2002.

MA GT, ROTH ME, GROSKOPF JC, TSAI FY, ORKIN SH, GROSVELD F, ENGEL JD, LINZER DI. GATA-2 and GATA-3 regulate trophoblast-specific gene expression in vivo. Development, v. 124, n. 4, p. 907-914, 1997.

MANJUNATHA, B.M., DEVARAJ, M., GUPTA, P.S.P., RAVINDRA, J.P., NANDI, S. Effect of taurine and melatonin in the culture medium on buffalo in vitro embryo development. Reproduction in Domestic Animals, v. 44, p. $12-$ 16, 2009.

MCARTHUR GA, LAHERTY CD, QUEVA C, HURLIN PJ, LOO L, JAMES L, GRANDORI C, GALLANT P, SHIIO Y, HOKANSON WC, BUSH AC, CHENG PF, LAWRENCE QA, PULVERER B, KOSKINEN PJ, FOLEY KP, AYER DE, EISENMAN RN. The Mad protein family links transcriptional repression to cell differentiation. Cold Spring Harbor Symposia on Quantitative Biology, v. 63, p. 423-433, 1998.

MCGRAW S, VIGNEAULT C, SIRARD MA. Temporal expression of factors involved in chromatin remodeling and in gene regulation during early bovine in vitro embryo development. Reproduction, v. 133, p. 597-608, 2007.

MEMILI E, PEDDINTI D, SHACK LA, NANDURI B, MCCARTHY F, SAGIRKAYA H, BURGESS SC. Bovine germinal vesicle oocyte and cumulus cell proteomics. Reproduction, v. 133, n. 6, p. 1107-1120, 2007.

MERKEL M, HEEREN J, DUDECK W, RINNINGER $F$, RADNER $H$, BRESLOW JL, GOLDBERG IJ, ZECHNER R, GRETEN H. Inactive lipoprotein lipase (LPL) alone increases selective cholesterol ester uptake in vivo, whereas in the presence of active LPL it also increases triglyceride hydrolysis and whole particle lipoprotein uptake. The Journal of Biological Chemistry. v. 277, p.7405-7411, 2002.

MILLER JW, SELHUB J, JOSEPH JA. Oxidative damage caused by free radicals produced during catecholamine autoxidation: protective effects of $\mathrm{O}$ methylation and melatonin. Free Radical Biology and Medicine, v. 22, n. 2, p. 241-249, 1996.

MOHAN M, THIRUMALAPURA NR \& MALAYER J. Bovine cumulus cells contain biologically active retinoid receptors that can respond to retinoic acid. Reproductive Biology and Endocrinology, v. 1, p. 104, 2003.

MOORE T, ABRAHAMSE, $\mathrm{H}$. Neuronal Differentiation of Adipose Derived Stem Cells: Progress So Far. International Journal of Photoenergy, 827540, 2014. 
MTANGO NR, POTIREDDY S, LATHAM KE. Oocyte quality and maternal control of development. International Review of Cell and Molecular Biology. v. 268, p. 223-290, 2008.

MURRAY P, EDGAR D. Regulation of programmed cell death by basement membranes in embryonic development. The Journal of Cell Biology, v. 150, p. 1215-1221, 2000.

NAGYOVA, E. Regulation of cumulus expansion and hyaluronan synthesis in porcine oocyte-cumulus complexes during in vitro maturation. Endocrine Regulations, v. 46, n. 4, p. 225-235, 2012.

NASI S, CIARAPICA R, JUCKER R, ROSATI J, SOUCEK L. Making decisions through Myc. FEBS Letters, v. 490, p. 153-162, 2001.

OKATANI Y, OKAMOTO K, HAYASHI $\mathrm{K}$ et al. Maternal-fetal transfer of melatonin in pregnant women near term Journal of Pineal Research, v. 25, p. 129-134, 1998.

OLAKOWSKA E, MARCOL W, KOTULSKA K, LEWIN-KOWALIK. The role of melatonin in the neurodegenerative diseases. Bratislavske lekarske listy Journal, v. 106, p. 171-174, 2005.

PAN H, SCHULTZ RM. Sox2 modulates reprogramming of gene expression in two-cell mouse embryos. Biology of Reproduction, v. 85, n. 2, p. 409-416, 2011.

PANDOLFI, P. P., ROTH, M. E., KARIS, A., LEONARD, M. W., DZIERZAK, E., GROSVELD, F. G., ENGEL, J. D. AND LINDENBAUM, M. H. Targeted disruption of the GATA3 gene causes severe abnormalities in the nervous system and in fetal liver haematopoiesis. Nature Genetics, v. 11, p. 40-44, 1995.

PICINATO, M.C., HIRATA, A.E., CIPOLLA-NETO, J., CURI, R., CARVALHO, C.R., ANHÊ, G.F., CARPINELLI, A.R. Activation of insulin and IGF-1 signaling pathways by melatonin through MT1 receptor in isolated rat pancreatic islets. Journal of Pineal Research, v. 44, 88-94, 2008.

QURESHI IA, GOKHAN S, MEHLER MF. REST and CoREST are transcriptional and epigenetic regulators of seminal neural fate decisions. Cell Cycle, v. 15, n. 22, p. 4477-4486, 2010.

REAVEN E, BOYLES J, SPICHER M, AZHAR S. Evidence for surface entrapment of cholesterol-rich lipoproteins in luteinized ovary. Arteriosclerosis, Thrombosis, and Vascular Biology, v. 8, p. 298-309, 1988.

REAVEN E, LUA Y, NOMOTO A, TEMEL R, WILLIAMS DL, VAN DER WESTHUYZEN DR, AZHAR S. The selective pathway and a high-density lipoprotein receptor (SR-BI) in ovarian granulosa cells of the mouse. Biochimica et Biophysica Acta, v. 1436, p. 565-576, 1999. 
REAVEN E, SHI XY, AZHAR S. Interaction of lipoproteins with isolated ovary plasma membranes. The Journal of Biological Chemistry, v.265, p. 1910019111, 1990.

REAVEN E, SPICHER M, AZHAR S. Microvillar channels: a unique plasma membrane compartment for concentrating lipoproteins on the surface of rat adrenal cortical cells. The Journal of Lipid Research, v. 30, p. 1551-1560, 1989.

REITER, R.J. Melatonin: Lowering the high price of free radicals. News in Physiological Sciences, v.15, p. 246-250, 2000.

REMALEY AT, STONIK JA, DEMOSKY SJ, NEUFELD EB, BOCHAROV AV, VISHNYAKOVA TG, EGGERMAN TL, PATTERSON AP, DUVERGER NJ, SANTAMARINA-FOJO $S$. Apolipoprotein specificity for lipid efflux by the human ABCA1 transporter. Biochemical and Biophysical Research Communications, v. 280, p. 818-823, 2001.

RISAU, W. Mechanisms of angiogenesis. Nature, v. 386, p. 671-674, 1997.

RODRIGUEZ KF, BLOMBERG LA, ZUELKE KA, MILES JR, ALEXANDER JE, FARIN CE. Identification of candidate mRNAs associated with gonadotropininduced maturation of murine cumulus oocyte complexes using serial analysis of gene expression. Physiological Genomics, v. 27, n. 3, p. 318-327, 2006.

RODRIGUEZ-OSORIO, N., KIM, I.J., WANG, H. Melatonin increases cleavage rate of porcine preimplantation embryos in vitro. Journal of Pineal Research, v. 43 , p. $283-288,2007$

SATO K, IWASAKI T, OGAWA K, KONISHI M, TOKMAKOV AA, FUKAMI Y. Low density detergent-insoluble membrane of Xenopus eggs: subcellular microdomain for tyrosine kinase signaling in fertilization. Development, v. 129, p. 885-896, 2002.

SEO M, LI Y-H. PFKFB3 regulates oxidative stress homeostasis via its Sglutathionylation in cancer. Journal of Molecular Biology, v. 426, n. 4, p. 830-842, 2014.

SEO T, AL-HAIDERI M, TRESKOVA E, WORGALL TS, KAKO Y, GOLDBERG IJ, DECKELBAUM RJ. Lipoprotein lipase-mediated selective uptake from low density lipoprotein requires cell surface proteoglycans and is independent of scavenger receptor class B type 1 . The Journal of Biological Chemistry, v. 275, p. 30355-30362, 2000.

SHAW L, SNEDDON SF, ZEEF L, KIMBER SJ, BRISON DR. Global gene expression profiling of individual human oocytes and embryos demonstrates heterogeneity in early development. PLoS One, v. 8, n. 5, e64192, 2013.

SHI Y, SAWADA J, SUI G, AFFAR EL B, WHETSTINE JR, LAN F, OGAWA $\mathrm{H}$, LUKE MP, NAKATANI Y: Coordinated histone modifications mediated by a CtBP co-repressor complex. Nature, v. 422, p. 735-738, 2003. 
SHI Y, LAN F, MATSON C, MULLIGAN P, WHETSTINE JR, COLE PA, CASERO RA. Histone demethylation mediated by the nuclear amine oxidase homolog LSD1. Cell, v. 119, p. 941-953, 2004.

SHI, J.M., TIAN, X.Z., ZHOU, G.B., WANG, L., GAO, C., ZHU, S.E., ZENG, S.M., TIAN, J.H.,LIU, G.S. Melatonin exists in porcine follicular fluid and improves in vitro maturation and parthenogenetic development of porcine oocytes. Journal of Pineal Research, v. 47, p. 318-323, 2009.

SLIWINSKI T, ROZEJ W, MORAWIEC-BAJDA A, MORAWIEC Z, REITER R, BLASIAK J. Protective action of melatonin against oxidative DNA damage: chemical inactivation versus base-excision repair. Mutation Research, v. 634, 220-227, 2007.

SMYTH N, VATANSEVER HS, MURRAY P, MEYER M, FRIE. Absence of basement membranes after targeting the LAMC1 gene results inlethality due to failure of endoderm differentiation. The Journal of Cell Biology, v. 144, p. 151-160, 1999.

SOLC P, SCHULTZ RM, MOTLIK J. Prophase I arrest and progression to metaphase I in mouse oocytes: comparison of resumption of meiosis and recovery from G2-arrest in somatic cells. Molecular Human Reproduction, v. 16, n. 9, p. 654-664, 2010.

SRIRAMAN V, RUDD MD, LOHMANN SM, MULDERS SM, RICHARDS JS. Cyclic guanosine 5'-monophosphate-dependent protein kinase II is induced by luteinizing hormone and progesterone receptor-dependent mechanisms in granulosa cells and cumulus oocyte complexes of ovulating follicles. Molecular Endocrinology, v. 20, n. 2, p. 348-361, 2006.

SU Y-Q, SUGIURA K, WIGGLESWORTH K, O'BRIEN MJ, AFFOURTIT JP, PANGAS SA, MATZUK MM, EPPIG JJ. Oocyte regulation of metabolic cooperativity between mouse cumulus cells and oocytes: BMP15 and GDF9 control cholesterol biosynthesis in cumulus cells. Development, v. 135, p. 111-121, 2008.

SUPRAMANIAM VG, JENKIN G, LOOSE J. Chronic fetal hypoxia increases activing A concentrations in the late-pregnant sheep. BJOG International Journal of Gynecology \& Obstetrics, v. 113, p. 102-109, 2006.

TALBOT P, SHUR BD, MYLES DG. Cell Adhesion and Fertilization: Steps in Oocyte Transport, Sperm-Zona Pellucida Interactions, and Sperm-Egg Fusion. Biology of Reproduction, v. 68, p. 1-9, 2003.

TAMMI RH, PASSI AG, RILLA K, KAROUSOU E, VIGETTI D, MAKKONEN K, TAMMI MI. Transcriptional and post-translational regulation of hyaluronan synthesis. FEBS Journal, v. 278, p. 1419,1428, 2011.

TAMURA H, NAKAMURA Y, TERRON MP. Melatonin and pregnancy in the human. Reproductive Toxicology, v. 25, p. 291-303, 2008. 
TAMURA, H., NAKAMURA, Y., KORKMAZ, A., MANCHESTER, L.C., TAN, D.X., SUGINO, N., REITER, R.J. Melatonin and the ovary: Physiological and pathophysiological implication. Fertility and Sterility, v. 92, p. 328-343, 2009.

TORRES JZ, SUMMERS MK, PETERSON D, BRAUER MJ, LEE J, SENESE S, GHOLKAR AA, LO YC, LEI X, JUNG K, ANDERSON DC, DAVIS DP, BELMONT L, JACKSON PK. The STARD9/Kif16a kinesin associates with mitotic microtubules and regulates spindle pole assembly. Cell, v. 147, p. 1309-1323, 2011.

TORRES-PADILLA, E., AND ZERNICKA-GOETZ, M. Role of TIF1a as a modulator of embryonic transcription in the mouse zygote. The Journal of Cell Biology, v. 174, p. 329-338, 2006.

TUMBALE P, WILLIAMS JS, SCHELLENBERG MJ, KUNKEL TA, WILLIAMS RS. Aprataxin resolves adenylated RNA-DNA junctions to maintain genome integrity. Nature, v. 506, p. 111-115, 2014.

VOICULESCU SE, ZYGOUROPOULOS N, ZAHIU CD, ZAGREAN AM. Role of melatonin in embryo fetal development. Journal of Medicine and Life, $v$. 7, p. 488,492, 2014.

WANG Y, WANG XH, FAN DX, ZHANG Y, LI MQ, WU HX, JIN LP. PCSK6 regulated by $\mathrm{LH}$ inhibits the apoptosis of human granulosa cells via activin $A$ and TGF $\beta 2$. Journal of Endocrinology, v. 222, p. 151-160, 2014.

WANG N, SILVER DL, COSTET P, TALL AR. Specific binding of ApoA-I, enhanced cholesterol efflux, and altered plasma membrane morphology in cells expressing $A B C 1$. The Journal of Biological Chemistry, v. 275, p. 33053-33058, 2000.

WEIGEL PH, DEANGELIS PL. Hyaluronan synthases: a decade-plus of novel glycosyltransferases. The Journal of Biological Chemistry, v. 282, p. 3677736781, 2007.

WINNIER G, BLESSING M, LABOSKY P, HOGAN B. Bone morphogenetic protein-4 is required for mesoderm formation and patterning in the mouse. Genes \& Development, v. 9, p. 2105-2116, 1995.

WOO, M.M., TAI, C.J., KANG, S.K., NATHWANI, S.P., PANG, S.F., LEUNG, P.C. Direct action of melatonin in human granulosa-luteal cells. The Journal of Clinical Endocrinology and Metabolism, v. 86, p. 4789-4797, 2001.

WU CS, LEU SF, YANG HY, HUANG BM. Melatonin Inhibits the Expression of Steroidogenic Acute Regulatory Protein and Steroidogenesis in MA-10 Cells. International Journal of Andrology, v. 22, p. 245-254, 2001.

XUE Y, GAO X, LINDSELL CE, NORTON CR, CHANG B, HICKS C, GENDRON-MAGUIRE $M$, RAND EB, WEINMASTER G, GRIDLEY T. Embryonic lethality and vascular defects in mice lacking the Notch ligand Jagged1. Human Molecular Genetics, v. 8, p. 723-730, 1999. 
YIN S, MA J, SHEN W. Effects of DNA damage on oocyte meiotic maturation and early embryonic development. Frontiers of Environmental Science \& Engineering, v. 1, n. 3, p. 185-190, 2014.

YOU A, TONG JK, GROZINGER CM, SCHREIBER SL: CoREST is an integral component of the CoREST- human histone deacetylase complex. Proceedings of the National Academy of Sciences, v. 98, p. 1454-1458, 2001.

ZHANG Y, DUAN X, CAO R, LIU HL, CUI XS, KIM NH, RUI R, SUN SC. Small GTPase RhoA regulates cytoskeleton dynamics during porcine oocyte maturation and early embryo development. Cell Cycle, v. 13, p. 3390-3403, 2014. 